UNIVERSIDADE DE SÃO PAULO

FACULDADE DE FILOSOFIA, LETRAS E CIÊNCIAS HUMANAS

DEPARTAMENTO DE HISTÓRIA

PROGRAMA DE PÓS-GRADUAÇÃO EM HISTÓRIA ECONÔMICA

CLAUDIA MARIA GUSSON

Movimento estudantil e repressão judicial: o regime militar e a criminalização dos estudantes brasileiros (1964-1979)

São Paulo 
UNIVERSIDADE DE SÃO PAULO

FACULDADE DE FILOSOFIA, LETRAS E CIÊNCIAS HUMANAS

DEPARTAMENTO DE HISTÓRIA

PROGRAMA DE PÓS-GRADUAÇÃO EM HISTÓRIA ECONÔMICA

\title{
Movimento estudantil e repressão judicial: o regime militar e a criminalização dos estudantes brasileiros (1964-1979)
}

\author{
Claudia Maria Gusson
}

Dissertação apresentada ao Programa de PósGraduação em História do Departamento de História Econômica da Faculdade de Filosofia, Letras e Ciências Humanas da Universidade de São Paulo, para obtenção de título de Mestre em História.

Orientadora: Profa. Drạ. Esmeralda Blanco Bolsonaro de Moura.

São Paulo

2008 
À Nair, minha mãe, por todo amor e apoio.

À minha inesquecivel irmã Oneida, que sempre estará comigo. 
Harmonia, paz com Deus. 


\section{Agradecimentos}

À minha orientadora Professora Dra. Esmeralda Blanco Bolsanaro, que confiou na minha capacidade e deu-me a oportunidade de realizar este trabalho. Obrigada pela acolhida, confiança e orientação.

À Professora Dra. Maria de Aparecida de Aquino, pelas contribuições bem-vindas sempre que eu recorri à sua ajuda.

Aos funcionários do Arquivo Edgard Leuenroth (AEL), da Universidade Estadual de Campinas, que tornaram possivel o meu eterno perder e achar nos processos do Projeto "Brasil: Nunca Mais".

Ao meu primo Edilson Gusson, que no início, quando eu ainda não havia superado o medo de dirigir na estrada após a morte da minha irmã, me levou várias vezes até o arquivo da Unicamp.

Ao meu grande amigo Leandro Brunelo, pelas dicas e confiança neste trabalho, pelos anos de História que ainda compartilhamos e desta amizade que me dá força.

Aos meus amigos Neemias O. da Silva e Rui César de Andrade Caetano, pela confiança e as palavras de incentivo e carinho quando eu estava desanimada.

Ao meu irmão Marcelo Gusson, por toda admiração e respeito que sente por mim, sempre confiando em minha capacidade.

Ao meu marido Sergio Henrique Demarchi, namorado e amigo, por sua incansável ajuda. Agradeço por desvendar os mistérios do Excel e acima de tudo, pela paciência e companheirismo durante a produção desta pesquisa.

À minha filha Helena, sempre carinhosa e compreensiva nestes três anos em que estive envolvida com este trabalho.

Enfim, agradeço a minha mãe Nair Gusson e ao meu pai Cláudio Gusson pelo amor incondicional e por me apoiarem sempre. 


\section{Resumo}

Durante os anos de 1964 a 1985, o regime militar brasileiro combateu os militantes contrários ao governo instaurado. O movimento estudantil teve grande representação nas lutas políticas e sociais, nesse contexto, tornou-se importante nos quadros da oposição. O governo fez uso de diversos aparatos para conter a ação dos estudantes, tais como a instauração de processos judiciais contra manifestações estudantis consideradas subversivas.

Este estudo pretende apresentar o perfil dos estudantes processados pelo regime militar, assim como o desempenho da acusação e da defesa nos julgamentos, com base em processos arquivados pelo Projeto Brasil Nunca Mais $(B N M)$, que tratam da ação estudantil. O acervo do Projeto é composto pela duplicação e análise dos processos procedentes do Superior Tribunal Militar (STM), pertinentes aos anos de 1964 a 1979.

A análise revelou que, aos olhos do Ministério Público, o estudante processado era subversivo e aliado a grupos de esquerda que pretendiam a derrubada do governo, ao passo que, para a defesa, era vitima da própria ingenuidade. Conforme o desempenho do procurador e do advogado, o juiz auditor determinava que o estudante era ou subversivo, ou um cidadão que poderia voltar a viver integrado de maneira construtiva na sociedade.

Palavras-chave: Movimento estudantil, Projeto Brasil Nunca Mais (BNM), regime militar. 


\section{Abstract}

From 1964 until 1985, when Brazil remained under military control, political prisoners were detained by government to be sued and convicted. The student movement, during the military regime had great representation in the political struggles and became an important opposition against the military regime that took power in April 1964.

This research intends to present the profile of the students sued for the military regime and how was the performance of the accusation and the defense in the judgments. This research is based mainly on the military court proceedings of actual trials, which were secretly photocopied by lawyers associated with the Catholic Church and analyzed by a team of researchers, the daring Project known as "Brazil: Never Again" (BNM). The project turned out public duplicate archives containing complete record of Brazil's military courts. This was achieved by bringing together the most of official legal proceedings of practically the political cases tried in Brazilian military courts between April 1964 and March 1979, specifically those that reached the Supreme Military Court.

The analysis of legal proceedings demonstrated that, according to the Public Military Ministry's point of view, the sued student was subversive and allied the leftist organizations to the resistance to that regime. On the other hand, the lawyer for the defense saw the student was a victim of its proper weakness. Depending on the performance of the accusation and the defense, the student could be judged either subversive or a citizen capable to live integrated in useful way in the society.

Keywords: Student movement, "Brazil: Never Again" (BNM), military regime. 


\section{SUMÁRIO}

RESUMO

v

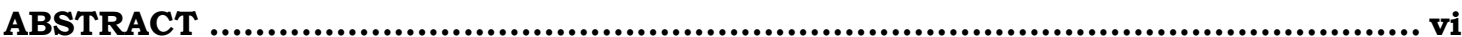

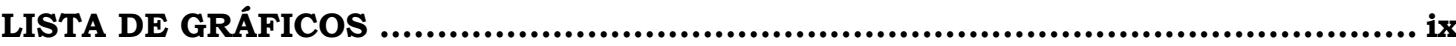

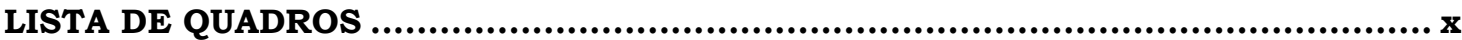

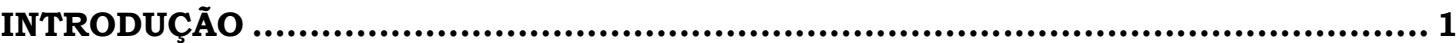

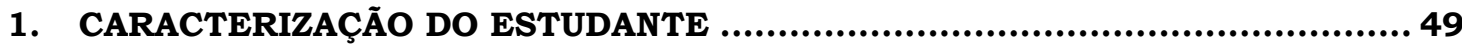

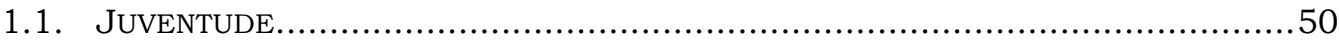

1.2. CARACTERIZAÇÃo dos Estudantes do PROJEto A - Atingidos .......................54

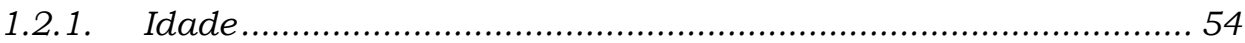

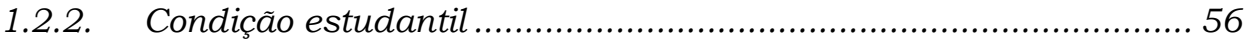

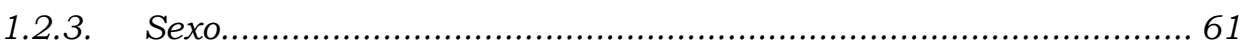

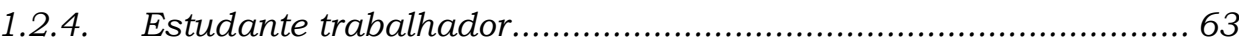

1.2.5. Distribuição e permanência dos denunciados por processos

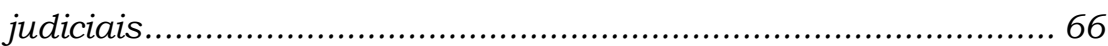

1.3. CARACTERIZAÇÃO DOS ESTUDANTES NOS ONZE PROCESSOS JUDICIAIS..................70

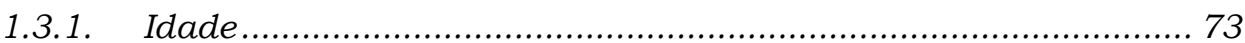

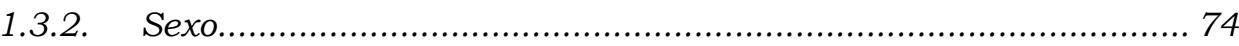

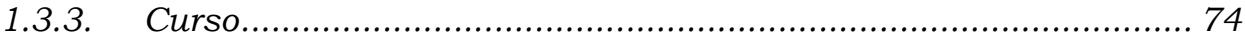

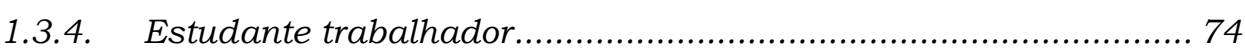

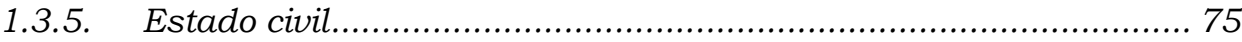

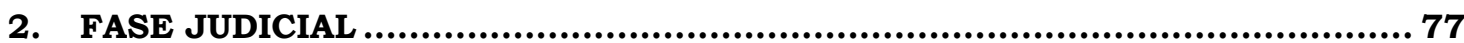

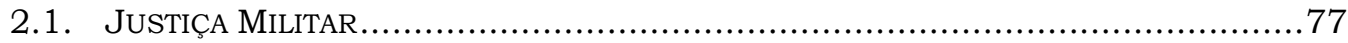

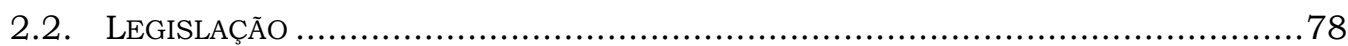

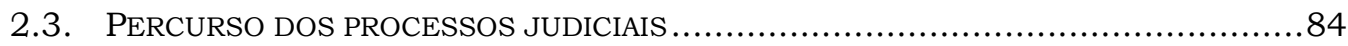

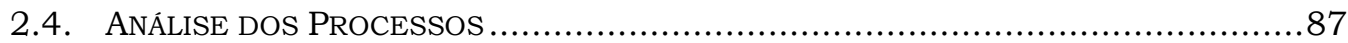

2.4.1. Distribuição de material subversivo............................................. 88

2.4.2. Depredação de bens e imóveis.................................................... 90

2.4.3. Comício-relâmpago e passeata estudantil ................................... 91

2.4.4. Posse de explosivos ................................................................. 93

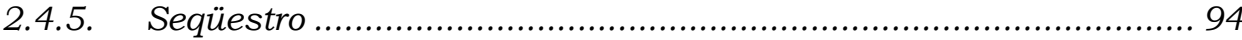

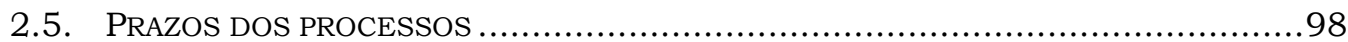




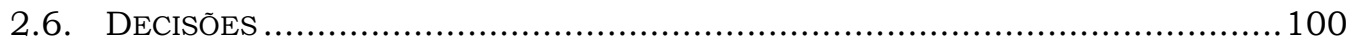

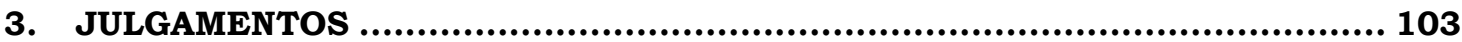

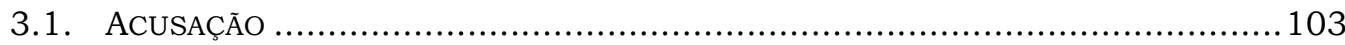

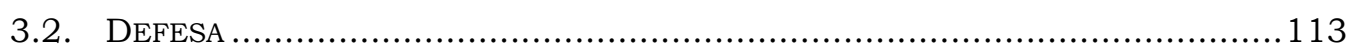

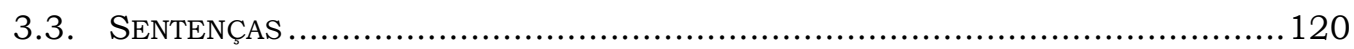

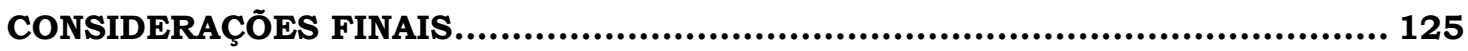

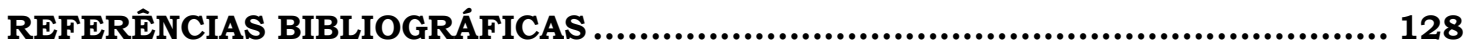




\section{Lista de Gráficos*}

Gráfico 1: Classificação dos Processos proposta pelo Projeto BNM 39

Gráfico 2: Presença de estudantes nos Processos Judiciais ...................................40

Gráfico 3: Representação da Fonte Documental - Projeto A - Atingidos.......................40

Gráfico 4: Estudantes denunciados no Projeto BNM ..........................................41

Gráfico 5: Estudantes denunciados em todo o universo do Projeto BNM .....................42

Gráfico 6: Estudantes denunciados nos Processos do Setor Estudantil.....................43

Gráfico 7: Estudantes por processos judiciais em todos os grupos (excluindo setor

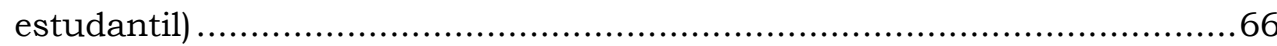

Gráfico 8: Estudantes por processo judicial no setor estudantil............................67

Gráfico 9: Participação estudantil distribuída por grupos de atuação nomeados pelo Projeto BNM .68

Gráfico 10: Desenvolvimento da atuação dos denunciados segundo classificação do BNM

* Os gráficos são de minha autoria, elaborados a partir de dados extraídos dos documentos. 


\section{Lista de Quadros *}

Quadro 1: Relação dos onze processos BNMs 44

Quadro 2: Estudantes denunciados em todos os Processos Judiciais do BNM distribuídos por faixa etária .55

Quadro 3: Estudantes denunciados nos Processos Judiciais do Setor Estudantil distribuídos por faixa etária. 55

Quadro 4: Caracterização Geral da População Atingida por Sexo 61

Quadro 5: Denunciados segundo sexo e faixa etária .62

Quadro 6: Ocupação declarada pelos denunciados 65

Quadro 7: Relação alfabética dos Denunciados nos respectivos BNMs . .71

Quadro 8: Relação de Idade em todos universos documentais. 73

Quadro 9: Setor Estudantil: onze processos: Motivos incriminatórios. .87

Quadro 10: Onze processos do Setor Estudantil: Motivos dos processos . 88

Quadro 11: Setor Estudantil: onze processos. Caracterização legal.... .96

Quadro 12: Setor Estudantil: onze processos. Artigos incriminatórios mais invocados .97

Quadro 13: Setor Estudantil: onze processos. Prazos para os julgamentos. 100

* Com exceção do quadro 4, os demais são de minha autoria, elaborados a partir de dados extraídos dos documentos. 


\section{Introdução}

A força fundamental desta luta é a aliança entre operários e camponeses. O papel do movimento estudantil é aliar-se a estas forças. O fundamental para nós estudantes é a aliança operário-camponesa-estudantil na luta pela tomada do poder.

O Movimento Estudantil se aproxima da aliança com os operários e camponeses enquanto força auxiliar que luta contra o inimigo comum: a ditadura expressa em seus interesses.

(União Nacional dos Estudantes de São Paulo)

(Anexo 878 - Carta politica da UNE, 29 Congresso Nacional dos Estudantes em São Paulo-Vinhedo 02/08/1967).

\section{Contextualização}

Após o golpe de 1964, o Brasil foi governado durante vinte anos por militares que se alternaram na liderança de um governo de exceção. Os protestos da sociedade foram silenciados pelos mecanismos autoritários que torturaram e até mataram a oposição a este governo. No entanto, o Estado não conseguiu evitar que grupos sociais manifestassem sua insatisfação contra sua politica repressiva. O movimento estudantil foi um dos setores que teve destaque no cenário de oposição ao governo. Essa atitude de enfrentamento do movimento estudantil contra a ordem vigente está exemplificada no trecho acima, extraído do periódico estudantil da União Nacional dos Estudantes (UNE). 
A insatisfação de alguns setores da sociedade resultou em uma resistência organizada que culminou com a articulação de alguns grupos de esquerda a deflagrarem a luta armada contra o governo. Constantemente, os jovens são referenciados como os principais integrantes destes grupos contestadores ao regime estabelecido, sendo o ambiente das universidades o principal reduto de contestação (RIDENTI, 1997, p.17). Dessa maneira, entendemos que estudar o movimento estudantil constitui-se em importante ferramenta para a compreensão da emergência do Estado autoritário no Brasil na década de 1960.

Este trabalho de pesquisa estuda a relação entre Estado e militantes estudantis, pretendendo entender a dinâmica jurídica do regime militar através da análise dos processos judiciais instaurados contra os estudantes durante os anos de 1964 a 1979. A pesquisa preconiza identificar os agentes sociais considerados inimigos do regime instaurado e busca compreender como funcionavam os aparelhos repressivos judiciais deste período, particularmente em relação aos estudantes.

Esta pesquisa espera contribuir para as discussões referentes ao governo militar e evidenciar as lacunas que ainda existem no esclarecimento dos acontecimentos ocorridos durante o regime de exceção instaurado nos idos dos anos de 1960. Após vinte e dois anos de consolidação da redemocratização brasileira, a sociedade ainda não alcançou o processo de transparência na elucidação desses acontecimentos. Por exemplo, a legislação brasileira ainda veta o acesso às informações através de leis restritivas e de controle dos arquivos públicos e privados ${ }^{1}$.

\footnotetext{
1 Lei de Arquivos no8. 159 de 1991, reguladora da política nacional de arquivos públicos e privados. Esta Lei reafirmou o direito de acesso à informação, determinado pela Constituição Federal (artigo 40), estabeleceu o princípio da classificação dos arquivos privados como de interesse público e social (artigos, 12, 13, 14, 15, 16), e dedica um capitulo inteiro ao acesso e sigilo (capitulo 50) (COSTA, 2003, p.179). Em 1997, esta Lei foi alterada pelo Decreto-lei no2.134 do Presidente Fernando Henrique Cardoso, que regulamentou a lei de 1991 com quatro classificações para os tipos de arquivos e determinou prazos de segredo para cada uma, prazos que atingiam no máximo o período de 60 anos. No entanto, em 2002, através da Lei no 4.553, também do ex-presidente Fernando Henrique Cardoso, os prazos dobraram, sendo que os da ordem de 50 anos podem ser prorrogáveis indefinidamente. Dessa maneira, alguns documentos classificados como secretos sobre o golpe de 1964, que poderiam ser liberados em 2004, agora só poderão ser divulgados em 2024. O presidente Luís Inácio Lula da Silva tem mantido esta política de restrição à documentação do periodo militar.
} 
Conforme Daniel Aarão Reis Filho, em crítica ao filme o que é isso, companheiro? (Bruno Barreto) baseado no livro de mesmo título da autoria de Fernando Gabeira (Rio de Janeiro, Codecri, 1979), existem muitas propostas de análise e interpretações sobre o período e algumas vezes a luta pela apropriação da memória coletiva desemboca em uma memória que

(...) apresenta os movimentos revolucionários dos anos 60 como uma grande aventura, no limite da irresponsabilidade: ações tresloucadas. Boas intenções, claro, mas equivocadas. Uma fulguração, cheia de luz e de alegria, contrapontos trágicos, uma ingenuidade, vontade pura, puros desejos, ilusões. Diante do profissionalismo da ditadura, o que restava àqueles jovens? Ferraram-se. Mas demos todas boas risadas. Afinal, o importante é manter o bom humor (REIS FILHO, 1997, p.34).

Esta pesquisa se contrapõe a este tipo de memória e busca contribuir para a elucidação e o não esquecimento do passado recente, gerando condições para um olhar cuidadoso de parte da história brasileira, sem o propósito de incentivar revanchismos. Dessa maneira, concordamos com Francisco Teixeira Silva (2001, p.311) quanto à necessidade de trazer à tona a discussão sobre a instauração e execução do regime militar, bem como sobre sua obra política e econômica, visando desta forma, impedir a instrumentalização do esquecimento como arma politica contra as democracias.

Os documentos públicos sigilosos classificam-se em quatro categorias:

I - ultra-secretos: os que requeiram excepcionais medidas de segurança e cujo teor só deva ser do conhecimento de agentes públicos ligados ao seu estudo e manuseio;

II - secretos: os que requeiram rigorosas medidas de segurança e cujo teor ou característica possa ser do conhecimento de agentes públicos que, embora sem ligação íntima com seu estudo ou manuseio, sejam autorizados a deles tomarem conhecimento em razão de sua responsabilidade funcional;

III - confidenciais: aqueles cujo conhecimento e divulgação possam ser prejudiciais ao interesse do País;

IV - reservados: aqueles que não devam, imediatamente, ser do conhecimento do público em geral.

(Decreto 2134 de 24 de janeiro de 1997) 


\section{O Regime Militar}

O Regime Militar instaurado no Brasil em 1964 foi resultado da ação de grupos civis e militares, que encerraram um periodo de democracia vigente no país no período de 1945 a 1964.

Vários trabalhos procuraram interpretar as causas da instauração do golpe, sendo que os primeiros datam do final dos anos sessenta. Estes trabalhos foram produzidos primeiramente pelos estudiosos das ciências sociais, enquanto os historiadores demoraram um período maior para estudar o tema, talvez pelas dificuldades metodológicas em abordar o tempo presente e, seguramente, pelas dificuldades de acesso às fontes documentais.

Algumas das primeiras análises foram as dos pesquisadores brazilianistas Thomas Skidmore e Alfred Stepan. O primeiro desenvolveu um trabalho factual, que serve como excelente referência para qualquer pesquisa sobre o regime militar, devido ao levantamento que o autor faz do período. A obra de Alfred Stepan é sua tese de doutoramento apresentada à Universidade Columbia em 1969 e publicada no Brasil em 1975. Neste trabalho, Os militares na politica: as mudanças de padrões na vida brasileira, Stepan argumenta que as intervenções dos militares na República foram comuns durante vários governos. Para esse autor, havia um padrão de relacionamento entre os militares e os civis, que ele caracterizou como "moderador". A intervenção dos militares acontecia somente para depor um governo e transferi-lo para outro grupo de políticos civis da oposição. O golpe de 1964 encerrou este relacionamento de "padrão moderador" e os militares, além de retirarem do poder os representantes legítimos, para substituí-los por outro grupo de políticos, passaram a compor o novo governo. Para Stepan, alguns fatores foram fundamentais para que este relacionamento de "padrão moderador" fosse quebrado no ano de 1964. Fatores como a quebra na hierarquia e na disciplina militar, a iminente ameaça de golpe por parte de João Goulart com o apoio dos comunistas e, por fim, a adoção de critérios políticos para promoções no Exército, sugeria aos militares que João Goulart teria a intenção de construir 
uma força militar que lhe fosse leal para um possivel golpe ${ }^{2}$. De acordo com Carlos Fico, a obra de Alfred Stepan contribuiu para a o início da produção de trabalhos referentes à instauração do novo governo, através da pesquisa em publicações oficiais e material jornalístico.

Cientistas politicos, sociais e economistas brasileiros começaram, a partir do final dos anos de 1960 a buscar as explicações para a instauração do golpe. Entre as análises de maior repercussão, podemos destacar a teoria da dependência que compreende, no seu modelo explicativo, as questões quanto ao atraso da industrialização do Brasil. Colaboradores desta teoria, como os sociólogos da Universidade Estadual de São Paulo (USP), Fernando Henrique Cardoso (1973), Octavio Ianni (1968) e Francisco Weffort (1978) apontaram para o colapso do Populismo como uma das causas do golpe militar. Para estes autores, o tipo de democracia populista praticada nos anos anteriores ao golpe foi a principal razão da instauração do governo militar. Ianni e Weffort, influenciados por Germani e Torcuato Di Tella ${ }^{3}$, argumentavam que o Populismo era uma característica comum aos países latino-americanos que passavam de uma economia oligárquica para uma economia moderna.

Para o efeito desta transição, foi necessária a implantação de um projeto nacionalista-estadista que visava à soberania nacional, com liderança de um governante populista. O Populismo caracteriza-se pela ocorrência de uma massificação de amplas camadas da sociedade que desvincula os indivíduos de seus quadros sociais de origem e os reúne na massa, relacionados entre si por uma sociabilidade periférica e mecânica; quando há uma perda da representatividade e da exemplaridade da classe dirigente; quando há a presença de um líder dotado de carisma de massas (WEFFORT, 1978). O líder populista atende às necessidades das classes dominantes, ao mesmo tempo em que consegue apoio das classes populares, através de uma

\footnotetext{
${ }^{2}$ Os comentários e análise da obra de Alfred Stepan foram baseados na trabalho de Carlos Fico que discute as mais importantes correntes historiográficas sobre o golpe de 1964. FICO, C. Versões e Controvérsias sobre 1964 e a Ditadura Militar. Revista Brasileira de História, São Paulo, n.47, 2004, p.29-60.

${ }^{3}$ Germani e Torcuato Di Tella foram intelectuais argentinos que na década de 1950, realizaram um trabalho pioneiro a respeito do Populismo na América Latina, tratando da experiência peronista (BITTENCOURT DA SILVA, 2003, p.104).
} 
relação intimista e clientelista que se desencadeia em uma manipulação das massas.

No que se refere ao conceito de massa, entendemos que massa é o conjunto de indivíduos que não tem a mesma consciência e algumas vezes não tem interesses comuns. A diferença entre massa e classe, segundo Thompson (1987), é que a classe representa um agrupamento de indivíduos que se reúnem com um interesse comum. Para este autor, classe social é entendida não como uma estrutura nem uma categoria, mas um fato produzido pelos agentes e pelas relações sociais. Uma classe é fruto de uma experiência de vida comum quando alguns homens sentem e articulam uma identidade de interesses entre si e contra outros homens, cujos interesses são diferentes e freqüentemente opostos (BODSTEIN, 1992, p.8).

Segundo a concepção destes estudiosos do populismo, a manipulação das massas, praticada pelo líder populista, impossibilitou a formação de uma consciência da classe operária e a existência de uma relação do líder manipulador com uma massa passiva de trabalhadores. Esta relação entra em colapso quando o líder populista não atende as expectativas das classes dominantes e passa a ingressar em reformas para satisfazer as classes populares. Para estes autores, o lider populista verteu para uma das classes e rompeu com o Estado de Compromisso ou pacto conciliador que tinha com a elite dominante. Neste momento, esta elite, associada com o setor militar, revida e consegue facilmente aniquilar uma massa popular sem consciência política. Para Ângela de Castro Gomes, o conceito de "Populismo" passou para a história com uma carga semântica altamente negativa. Os politicos populistas são estigmatizados como enganadores do povo, por suas promessas jamais cumpridas e como aqueles capazes de articular retórica fácil com falta de caráter (GOMES, 2001).

Esta abordagem parte do pressuposto de que a sociedade brasileira dos anos de 1960 não era uma massa sem consciência. A perspectiva que mais se aproxima do atual trabalho são as obras de Ângela de Castro Gomes (2001) e Daniel Aarão Reis Filho (2001), que suprimem o conceito de Populismo e o substituem pelo de Trabalhismo. Nesta abordagem, havia sim, uma 
conscientização política na população nos anos anteriores ao golpe de 1964 . Neste período, os direitos trabalhistas foram ampliados, tais como as garantias de emprego, a qualificação do trabalhador e, além disso, havia um otimismo nas classes populares para a realização das reformas de base que constavam na agenda do presidente João Goulart.

Para Daniel Aarão Reis Filho (2001), a esquerda brasileira não foi manipulada pelo Populismo, na verdade, o que aconteceu em 1964 foi um erro estratégico por parte da esquerda, que acreditou ter mais poder e organização do que de fato possuía. Os principais partidos da esquerda, o Partido Comunista Brasileiro (PCB) e o Partido Trabalhista Brasileiro (PTB), foram capazes de atrair as massas populares porque atendiam às suas necessidades e tornaram-se um canal político de representatividade da classe trabalhadora, tanto que, neste período, várias reivindicações foram atendidas e uma verdadeira proteção trabalhista foi forjada durantes os anos de 1946 a 1964.

Alguns autores apontaram para a versão conspiratória tramada entre alguns segmentos da sociedade, tais como as forças armadas anticomunistas orquestradas com a Escola Superior de Guerra (ESG)4, parte do empresariado

${ }^{4}$ A Escola Superior de Guerra (ESG) foi criada oficialmente, em 1948, em um contexto de final de Segunda Guerra em pleno cenário de "Guerra Fria". No entanto, de acordo com Creuza Berg (2002), desde o tempo do Império ocorreu uma crescente profissionalização do Exército e uma valorização da tecnologia. A criação do Instituto Politécnico, em 1874, foi um dos primeiros passos para a profissionalização dos militares. Para Creuza Berg a "aparente contradição dessa nova exigência em relação ao antiintelectualismo presente nas fileiras do Exército (...), talvez se justifique pela própria cisão no meio militar, que dá origem às duas correntes mais representativas: a 'Linha Dura', mais ligada ao comando das tropas, e operações antiguerrilhas, que se contrapunha à linha denominada 'Sorbonne', mais intelectualizada, ligada à ESG" (p.32). Acreditamos que o governo militar instaurado era mais complexo e com mais desdobramentos ideológicos do que as duas limitações de uma frente de 'Linha Dura' e outra 'Sorbonne', contudo, estas duas correntes tornaram-se mais evidentes dentro do universo militar. Como explicou Creuza Berg, "a linha 'Sorbonne' tinha convicção de atuação do Exército como ordenador e disciplinador da sociedade e da própria tomada do poder político pelos militares, em um processo de transição de médio prazo, ao final do qual o poder seria restituído às classes dominantes da sociedade civil. A 'Linha Dura', no entanto, encarava o Exército como elemento de manutenção da ordem estabelecida. Assim, sua permanência no poder seria limitada enquanto essa 'ordem', considerada 'ameaçada', não estivesse a salvo, pois julgava a sociedade civil incapaz de dirigir esse processo (...)" (p.15).

A ESG, em sintonia com o cenário de Guerra Fria e o mundo dividido em blocos, reformula o conceito de Segurança Nacional, que até este período poderia ser entendido como ligado à proteção de fronteiras contra ataques externos e sua doutrina passa a seguir os "parâmetros das doutrinas das escolas norte-americana e francesa, tendo por eixo central a Segurança Nacional, o que equivale, no tocante à opção brasileira, a uma luta contra a infiltração comunista em todos os âmbitos da sociedade" (BERG, 2002, p.32). 
nacional, do capital internacional, dos latifundiários, dos conservadores, da igreja católica e dos partidos políticos. Um dos autores a elaborar a idéia de conspiração foi René Armand Dreifuss (1981), que analisou a participação da imprensa na preparação do golpe. De acordo com Dreifuss, o capital multinacional instaurado desde os tempos de Juscelino Kubitschek passou a enfrentar dificuldades com a agenda populista do governo de João Goulart, de tal maneira que grupos que representavam este capital estrangeiro passaram a apoiar e organizar segmentos da sociedade em uma grande onda de rejeição contra o Estado. A teoria de conspiração também foi defendida por Moniz Bandeira (1978), que tratou da relação do governo americano com os golpistas e destacou a ação do governo norte-americano através da organização da Operação Brother Sam, uma operação militar de tropas americanas que estavam de prontidão, na costa brasileira, para conter qualquer reação do presidente João Goulart.

Outras abordagens explicativas acerca dos motivos da instauração do governo militar no ano de 1964 estão diretamente ligadas à posição que o Brasil ocupava no Sistema Capitalista internacional. Em primeiro lugar, o cientista político Guilhermo O’Donnell desenvolveu a teoria dos Estados autoritárioburocráticos para explicar os tipos de governos autoritários que emergiram na América Latina a partir da década de 1960. Para esse autor, vários países latino-americanos sofreram, naquele período, tensões sociais, econômicas e políticas decorrentes do tipo de modernização capitalista dependente. Esse tipo de análise está vinculado às teorias do "capitalismo dependente" no qual entende-se que o Sistema Capitalista estava dividido em regiões de influências “centrais" e "periféricas". Dessa maneira, as razões e manutenção do novo governo instaurado nos países da América Latina resultam da dinâmica da relação de dependência entre os países "dependentes" com os países "centrais" (AQUINO, 1994, p.10). Nesta abordagem, o autoritarismo empregado no Brasil tinha implicações resultantes da dominação externa, como o caso da influência das corporações multinacionais no país.

Para Guilhermo O’Donnell, três fatores contribuíram para a instauração dos Estados autoritário-burocráticos nos países da América Latina. Inicialmente, a questão da industrialização, que necessitou de investimentos 
internacionais para uma produção doméstica de bens intermediários e de capital. Esse panorama de investimentos exigia estabilidade politica e combate às crises econômicas, o que desencadeou uma política econômica mais ortodoxa e orquestrada aos interesses internacionais.

O segundo fator foi a ameaça da participação politica das classes populares. A nova fase de industrialização adotou medidas políticas econômicas que não satisfaziam os setores sociais populares que, ainda fortalecidos pelo período populista, passaram a reagir através de manifestação de greve. Ou seja, o endurecimento da política econômica enfrentava a ameaça do engajamento político das classes trabalhadoras.

O terceiro aspecto foi a atuação dos tecnocratas civis e militares no Estado autoritário-burocrático, tanto no processo de industrialização quanto na ocupação de altos cargo no Governo. Foi fundamental a ação destes agentes sociais para gerar as condições da continuidade da industrialização, mesmo que para isso tenham promovido a manutenção de regimes autoritários, que não admitiam manifestações populares contrárias às metas políticas e econômicas do governo5.

Outra abordagem baseada na inserção do Brasil no Sistema Capitalista é a utilizada por Maria Helena Moreira Alves (1984) que busca explicação de caráter econômico para as razões do golpe. A autora tem sua filiação teórica ligada à teoria da dependência e ao marxismo, que aponta para a incapacidade do Brasil de adaptar-se ao sistema econômico mundial como um dos principais fatores responsáveis pela deflagração do golpe de Estado. Para a mesma, o desenvolvimento econômico brasileiro é do tipo dependente.

O conceito de desenvolvimento é trabalhado pela autora como a capacidade que uma sociedade possui em continuar avançando. Dois tipos de desenvolvimento são apontados, um do tipo autônomo e outro do tipo dependente. No primeiro tipo de desenvolvimento, a sociedade tem capacidade

\footnotetext{
${ }^{5}$ Resumo dos três fatores da instalação do Estado autoritário-burocrático baseado em: MATTOS, M.A.V.L. Em nome da segurança nacional: Os processos da Justiça Militar contra a Aliança Libertadora Nacional, (1969-1979). São Paulo: Dissertação de Mestrado em História Social, FFLCH - USP, 2002.
} 
de auto gerar condições para o seu desenvolvimento, sem necessitar de fatores externos. No segundo tipo, como o do Brasil, a sociedade não gera seu desenvolvimento sem as contribuições de fatores externos. Desta maneira, esta sociedade situa-se em uma situação periférica que dependerá dos países do centro econômico para garantir o seu próprio desenvolvimento. Para o Brasil passar para a fase de desenvolvimento autônomo, seria necessária uma grande mudança nas diretrizes econômicas e industriais, além de grandes investimentos. Neste ponto, a autora detecta essa dificuldade de transição como o embate econômico que gerou os motivos da queda de João Goulart. A nova formatação de Estado, instaurada com o golpe, foi nomeada pela autora de Estado de Segurança Nacional (ALVES, 1984, p.8, apud AQUINO, 1994).

\section{Doutrina ou Ideologia de Segurança Nacional}

O aspecto relevante na obra de Maria Helena Moreira Alves (1984) que interessa a esta pesquisa é a sua concepção de doutrina de segurança nacional e de desenvolvimento, o que ela chama em muitos momentos de ideologia de segurança nacional. A ideologia de segurança nacional tem a função de legitimar o Estado autoritário, que passa a adotar um tipo de desenvolvimento econômico excludente e de concentração de renda. A doutrina de segurança nacional também é o arcabouço para a implantação e manutenção das leis de Segurança Nacional que preconizaram o combate e a repressão de crimes considerados subversivos e de ameaça à segurança nacional.

A concepção de ideologia adotada por Maria Helena Moreira Alves é a de Marx em Ideologia Alemã (1984): a produção da ilusão, um processo pelo qual se forjam os interesses particulares como se eles fossem os interesses gerais da sociedade. Com a utilização da doutrina de segurança nacional, o projeto excludente de desenvolvimento do Estado autoritário, que atende o interesse de uma minoria da sociedade, passa a ser aceito pela maioria da população.

Outro conceito elaborado por Maria Helena Moreira Alves e utilizado nesta pesquisa refere-se à teoria da perseguição ao "inimigo interno", segundo a qual o Estado investe na repressão para eliminar organizações de esquerda que ameaçam a ordem estabelecida (1984, p.37). Por último, utilizaremos a proposição da autora, que entende a relação entre Estado e a oposição como 
uma relação dialética. Para esta autora, as medidas repressivas e a resistência armada aconteceram concomitantemente e foram dialéticas em um intenso embate de ações e reações.

Em relação à perseguição ao "inimigo interno", os processos judiciais instaurados contra os estudantes atendem à proposição de reprimir a ameaça interna. Esses processos eram fundamentados na Lei de Segurança Nacional, que forneceu sustentação legal à repressão de qualquer pessoa ou grupo que se opunha à politica do Estado de Segurança Nacional. A ESG em sintonia com o cenário de Guerra Fria e o mundo dividido em blocos, reformulou a Doutrina de Segurança, que até este período poderia ser entendido como ligado à proteção de fronteiras contra ataques externos. Deste modo, essa nova concepção passa a seguir os "parâmetros das doutrinas das escolas norte-americana e francesa, tendo por eixo central a Segurança Nacional, o que equivale no tocante à opção brasileira, a uma luta contra a infiltração comunista em todos os âmbitos da sociedade" (BERG, 2002, p.32).

Essa teoria advertia para a ameaça iminente do comunismo internacional, já que este poderia atuar através da guerra revolucionária caracterizada por um conflito interno estimulado ou auxiliado pelo exterior, inspirado geralmente em uma ideologia que buscava a conquista do poder pelo controle progressivo da nação (ALVES, 1984, p.37).

A Lei de Segurança Nacional legitimou as investigações, a instauração de processos e criminalização dos opositores ao regime autoritário. Esses crimes, considerados contra a segurança nacional, são os que ofendem a ordem econômica, política e social do Estado, a sua defesa interna e externa ${ }^{6}$.

Atendendo às condições históricas de cada período, várias alterações ocorreram na legislação brasileira para atender os problemas ligados à segurança do país. No século XX, durante a ditadura de Getúlio Vargas, foi editada a Lei 244, de 11 de setembro de 1936, que criou o Tribunal de Segurança Nacional como órgão da Justiça Militar, para funcionar "sempre que

\footnotetext{
${ }^{6}$ Crimes já previstos desde o Código Penal do Império de1830, nos artigos 68, 69 e 107.
} 
[fosse] decretado estado de guerra" (art. 1) e equiparado ao estado de emergência (FERREIRA, 1982, p.40).

Com a queda do Estado Novo e aplicação da Lei Constitucional no14, de 1945, extinguiu-se o Tribunal Nacional, passando para a Justiça Militar a competência dos crimes contra a segurança externa e tornando-se competência da justiça comum os crimes contra a segurança interna. Desta maneira, este tipo de delito passou a figurar em dois tipos de diplomas penais: o Código Penal Militar (Decreto-Lei 6.227, de 24 de janeiro de 1944: arts. 188 a 189) e o Decreto Lei 413, de 1938, que vigorou até a Lei no 1.802 , de 5 de janeiro de 1953.

Com o golpe de 1964, a Lei 1.802 já não atendia às questões ligadas à segurança nacional na forma como era proposta pelo novo modelo de governo instaurado no regime militar. Neste contexto, a ESG aplicava uma Doutrina de Segurança Nacional e Desenvolvimento baseada em um pensamento que incluía uma teoria de guerra, uma teoria de revolução e subversão interna, "uma teoria do papel do Brasil na politica mundial e de seu potencial geopolítico como potência mundial, e um modelo específico de desenvolvimento econômico associado-independente" (ALVES, 1984, p. 26).

Atendendo à nova realidade, foi editada a primeira lei de Segurança Nacional do regime militar, na forma do Decreto-Lei no 314 de 13 de março de 1967. Esta lei reconhece a competência da Justiça Militar e a aplicação do Código de Justiça Militar para o processo e julgamento dos crimes previstos neste decreto (AQUINO, 1994, p. 239).

A nova Lei de Segurança Nacional reivindicava uma postura antisubversiva de toda a sociedade, já que a defesa da segurança nacional deveria ser responsabilidade não só das Forças Armadas, como de toda pessoa natural ou jurídica 7 da sociedade civil. Dessa maneira, "indivíduos e organizações poderiam ser considerados criminalmente responsáveis por deixar de fornecer

\footnotetext{
7 "Pessoa é o ser, a que se atribuem direitos e obrigações. Equivale, assim, a sujeito de direitos". Enquanto o homem é a pessoa natural, capaz de ter direitos e assumir obrigações, as pessoas jurídicas são entidades com personalidade própria e capazes, também, de assumir direitos e obrigações (BELIVÁCQUIA, Código Civil, vol. I, pág.168, 6ª ed. Apud COGAN, 1976, p.3).
} 
informação sobre as atividades daqueles considerados pelo Estado como parte do inimigo interno" (ALVES, 2005, p. 108). Nas Disposições Preliminares, artigo 1 da Lei de Segurança Nacional, fica claro esse pensamento:

Art. $1^{\circ}$ Toda pessoa natural ou jurídica é responsável pela segurança nacional, nos limites definidos em lei (Decreto-Lei №314, de 13 de março de 1967).

Tomando como base os manuais da ESG e uma entrevista com o coronel Geraldo Cavagnari ${ }^{8}$, Creuza Berg concluiu que o conceito de Defesa Nacional foi ampliado para Segurança Nacional, "o que [significou] um maior envolvimento das Forças Armadas na politica interna e na sociedade, uma vez que a própria doutrina reza que a Segurança Nacional não é de responsabilidade apenas do Exército, mas da sociedade com um todo" (2002, p. 33).

Entre 1967 a 1983, período em que vigorou a lei de Segurança Nacional, foram decretados vários textos regulando normas a respeito ${ }^{9}$. Nesta pesquisa, interessam principalmente, em função do recorte temporal, os textos legais dos anos de 1967 a 1969.

No Decreto-lei no898, novas regras fortaleceram as medidas repressivas anteriormente estabelecidas, como a possibilidade de manter o indiciado ${ }^{10}$ incomunicável por até dez dias para as necessárias averiguações (Artigo 59, § $1^{\circ}$ ), além da introdução da pena de morte e da prisão perpétua (Capítulo IV). Dessa maneira, a investigação e repressão do governo eram legitimadas e funcionavam através de processos fundamentados na Lei de Segurança Nacional.

Outro recurso utilizado pelo Governo para a manutenção do poder foi a instauração de Atos Institucionais (AIs). O Ato Institucional № 1 foi o primeiro de uma série de Atos que objetivaram legitimar as ações do novo governo e

\footnotetext{
8 Núcleo de Estudos Estratégicos da Unicamp apud BERG, 2002, p.33.

9 Leis de Segurança Nacional: Decreto-lei no314 de 13 de março de 1967. Lei no. 510 de 20 de março de 1969, regulamentada pelo Decreto-lei no510 de 20 de março de 1969. Ambos revogados pelo Decreto-lei 898, de 1969. Decreto-lei no. 975 de outubro de 1969. Lei no. 5.786 de 27 de junho de 1972. Lei no. 6.620 de 17 de dezembro de 1978 e Lei no. 7.170 de 14 de dezembro de 1983. Leis de funcionamento e regulamentação da Justiça Militar foram decretadas em outubro de 1969: Decretos-leis 1001 (Código Penal Militar), 1002 (Código de Processo Penal Militar) e 1003 (Lei de Organização Judiciária Militar).

10 Durante o Inquérito, o preso é denominado indiciado e, na fase judicial, denunciado.
} 
regulamentar as novas instituições politicas, sociais e econômicas estabelecidas. A grande maioria dos Atos Institucionais instaurados limitou os direitos e garantias individuais; cassaram mandatos e direitos políticos; extinguiram partidos e suspenderam eleições entre outras medidas repressivas. O Ato Institucional №1 limitou os poderes do Congresso Nacional e abriu caminho para a "Operação Limpeza"11. Neste período, os principais atingidos foram, desde o funcionalismo público, os militares ligados ao governo destituído de João Goulart e as lideranças sindicais (ALVES, 1984).

Em 11 de junho de 1964 encerrou-se o prazo que o AI-1 estabeleceu para as cassações, com um saldo de 3 ex-presidentes da República cassados (Juscelino Kubitschek, Jânio Quadros e João Goulart); e mais 6 governadores de Estado, como Miguel Arraes de Pernambuco; 2 senadores, 63 deputados federais e centenas de deputados estaduais e vereadores. No Exército, 77 oficiais foram reformados, na Marinha, 14 e, na Aeronáutica, 31. Dez mil funcionários públicos foram demitidos e abriram-se 5000 investigações atingindo 40.000 pessoas (ARQUIDIOCESE DE SÃO PAULO, 1985, p.61).

Então em outubro de 1965 foi decretado o Ato Institucional № 2, que conferia mais poderes ao presidente para cassar mandatos e direitos políticos, extinguia todos os partidos políticos existentes, deixando existir apenas dois: um governista e outro de oposição consentida. Os dois partidos criados foram a ARENA (Aliança Renovadora Nacional), que apoiava o governo e o MDB (Movimento Democrático Brasileiro), encarregado de fazer a oposição controlada ao governo. O AI-2 deu condições para que vários Atos Complementares fossem instituídos, tais como, o que tornou a eleição indireta para presidente da República e o que aumentou o poder da Justiça Militar. Com o AI-2, todos os civis e militares acusados de infringir a Lei de Segurança Nacional passaram a ser processados pela Justiça Castrense:

\footnotetext{
11 A "Operação Limpeza" foi uma série de medidas adotadas pelo Estado para reprimir qualquer tipo de oposição política, econômica e social. O Ato Institucional №1 permitiu o uso dos Inquéritos Policiais Militares (IPMs) e o uso de forças repressivas para neutralizar qualquer cidadão que pretendesse opor-se organizadamente a politicas em aplicação. O Decreto-lei №53.897/64 institui os IPMs, já previstos no AI-1. Dessa maneira, foram criadas Comissões especiais de inquéritos em todos os niveis do governo federal (ALVES, M.H.M, op., p.56-79).
} 
$\S 2^{\circ}$ A competência da Justiça Militar nos crimes referidos no parágrafo anterior com as penas aos mesmos atribuídas, prevalecerá sobre qualquer outra estabelecida em leis ordinárias, ainda que tais crimes tenham igual definição nestas leis (Ato Institucional Número 2, artigo $8^{\circ}$ )

Outro aspecto importante do AI-2, observado por Maria Aparecida de Aquino (1994, p. 239) e já mencionado através da interpretação de Creuza Berg (2002, p. 33), é que o sentido de Segurança Nacional passou da preocupação com o inimigo externo para o inimigo interno. Como citado por Maria Aparecida de Aquino, o artigo 108 da Constituição de 1946 apresentava a seguinte redação:

§ 1 - Esse foro especial poderá estender-se aos civis, nos casos, expressos em lei, para a repressão de crimes contra a segurança externa [grifo meu] do País ou as instituições militares.

O artigo 8o do AI-2 trouxe a seguinte instrução:

O § 1o do art. 108 da Constituição passa a vigorar com a seguinte redação:

§ 10 Esse foro especial poderá estender-se aos civis, nos casos expressos em lei para repressão de crimes contra a segurança nacional [grifo meu] ou as instituições militares.

$\S 2^{\circ}$ A competência da Justiça Militar nos crimes referidos no parágrafo anterior com as penas aos mesmos atribuidas, prevalecerá sobre qualquer outra estabelecida em leis ordinárias, ainda que tais crimes tenham igual definição nestas leis.

Em 5 de fevereiro de 1966, foi decretado o Ato Institucional № 3, que estabeleceu o fim das eleições diretas para governadores e prefeitos das capitais. Os governadores passaram a ser indicados pelo presidente e os prefeitos eram indicados pelos governadores. O Ato Institucional № 4 também foi decretado em 1966 e deu poderes para o Governo elaborar uma Nova Constituição. O recesso do Congresso foi suspenso e, no período de 12 de 
dezembro até 24 de janeiro de 1967, o Congresso votou o projeto de Constituição elaborado pelo Executivo. A Constituição de 1967 liberava de apreciação judicial os atos praticados pelo Comando Supremo da Revolução de 31 de março, ou seja, as ações tomadas pelas Autoridades Militares no Governo. O julgamento de civis pelo Tribunal Militar também foi assegurado por esta Constituição. Em 1967, também foi decretada a Lei de Imprensa ${ }^{12}$ que proibiu as críticas ao Governo e estabeleceu a possibilidade de condenação em até 10 anos para os infratores.

O ano de 1968 foi de contestação ao regime militar e várias manifestações de protesto entraram na agenda de grupos e entidades sociais após um período de reorganização e reconstrução, necessário em virtude da "Operação Limpeza" executada no início do regime. Mesmo com a repressão policial, a oposição ao regime ganhou força nas ruas, nas fábricas e nas faculdades. Em contrapartida, o governo militar instaurou mais um Ato Institucional, o de número 5. Com a decretação deste Ato, foi negado o recurso de Habeas-Corpus ${ }^{13}$ que era bastante utilizado pelos processados judicialmente desde a Constituição de 1891. O Habeas-Corpus era concedido sempre que houvesse o perigo de violência ou coação por ilegalidade ou abuso de poder.

A decretação do Ato Institucional №5 também respondia a um incidente parlamentar ligado ao deputado Márcio Moreira Alves. O deputado teria feito um discurso que foi considerado ofensivo para as Forças Armadas. O Governo

12 Lei № 5.250, e 09/02/1967.

13 Habeas corpus, etimologicamente significa em latim "Que tenhas o corpo". A expressão completa é habeas corpus ad subjiciendum. É uma garantia constitucional outorgada em favor de quem sofre ou está na iminência de sofrer coação, ameaça ou violência de constrangimento na sua liberdade de locomoção por ilegalidade ou abuso de poder da autoridade legítima. Além disso, serve como instrumento de controle da legalidade do processo penal. A expressão indica a essência do título, ou seja, que se toma a pessoa presa para apresentá-la ao juiz a fim de ser julgada. O objetivo básico é a tutela da liberdade física, no sentido de ir, ficar e vir, ou da liberdade de locomoção (NORONHA, 1979, p.403 apud BUCK, 2001). "Ter corpo, ou tomar o corpo, é uma metáfora, que significa a liberdade de ir e vir, o poder de locomoção, o uso dessa liberdade de locomoção livremente, salvo restrições legais a todos impostas indistintamente". (FERREIRA, 1988, p.6 apud Buck, 2001). Habeas corpus é o "(...) remédio contra a prisão ilegal", (...) "habeas-corpus é das maiores conquistas jurídicas do homem, no âmbito da liberdade física" (ACOSTA, 1978, p.512 apud Buck 2001). O intuito do habeas corpus era proteger a liberdade de locomoção, evitando tratamentos injustos antes do julgamento, especialmente em épocas dificeis para tal garantia, por força da deficiência do desenvolvimento do direito processual penal (FERREIRA, 1988, p.5 apud Buck, 2001). Edgard Magalhães Noronha define o habeas corpus como "(...) o meio mais expedito que a lei dispõe contra a violação ou ameaça à liberdade de locomoção da pessoa". (NORONHA, 1979, p.406. apud Buck, 2001). 
pediu, então, autorização ao Congresso para processar o deputado, já que a Constituição de 1967 tinha confirmado o direito à imunidade parlamentar e que o AI-2, que dava este tipo de poderes para o Executivo, havia expirado. $\mathrm{O}$ pedido do governo foi recusado e, no dia seguinte, 13 de dezembro de 1968, foi decretado o AI-5.

O AI-5 ampliou a utilização do Aparato Repressivo do Estado de Segurança Nacional e restringiu a ação do Judiciário:

Podiam-se efetuar prisões sem acusação formal e sem mandado. Juntamente com as restrições ao Judiciário, isto impedia advogados e outros que defendiam os presos politicos de aplicar as garantias legais. Não podiam assim evitar sérios abusos de poder e a tortura dos presos politicos (ALVES, 1984, p.134).

Além disso, concedeu, ao chamado "sistema" de informações, autoridade para investigar e punir a vida de milhares de brasileiros.

Durante o governo de Arthur da Costa e Silva, que durou até 31 de agosto de 1969, mais seis Atos Institucionais foram decretados com o objetivo de moldar juridicamente a máquina repressiva em que se tornou o governo militar brasileiro.

O AI- 6 ampliou os poderes da Justiça Militar para processar e julgar os civis nos casos expressos em lei para repressão de crimes contra a Segurança Nacional. O AI-7 regulamentou a remuneração e o funcionamento das câmaras municipais e assembléias legislativas. $\mathrm{O}$ AI-8 viabilizou Reformas Administrativas no Governo, na esfera federal, nos estados e nas suas extensões governamentais para a contenção de despesas públicas. Com a decretação do AI-9 a União poderia desapropriar propriedade territorial para a Reforma Agrária mediante o pagamento de justa indenização. O AI-10 agravava as penalidades contra os cidadãos punidos na revolução, principalmente para aqueles que tinham cargos eletivos. O AI-11 regulamentou as eleições municipais de 1969.

Decretado em 31 de agosto de 1969, O AI-12 legalizou a instauração de uma Junta Militar com três Ministros, cada um representando uma das Armas. 
A Junta Militar assumiu o governo por dois meses, na ausência do presidente Arthur da Costa e Silva que se afastou do cargo em função de problemas de saúde. Para Heller, este Ato foi decretado com o objetivo claro de não permitir que o vice-presidente Pedro Aleixo assumisse o poder no lugar de Costa e Silva. Na verdade, foi "um golpe dentro do golpe" (HELLER, 1988, p. 670 e MARTINS FILHO, 1987, p.95). Afinal, Pedro Aleixo foi um dos que se opuseram abertamente contra o AI-5.

O AI-13 foi publicado após o seqüestro do embaixador americano, que resultou na liberação de 15 presos políticos em troca da libertação do embaixador. Com este Ato, os presos libertados foram exilados, uma vez que foi instituída pena de banimento do território nacional a todos os cidadãos nocivos, inconvenientes e perigosos à segurança nacional (Artigo $1^{\circ}, 1969$ ).

O AI-14 publicado pela Junta Militar, em setembro, modificava a Constituição de 1967 para a aplicação da pena de morte em caso de "guerra externa psicológica adversa, ou revolucionária ou subversiva nos termos que a lei [determinasse]" (HELLER, 1988, p.676).

O AI-15, editado em 15 de setembro, confirmava a data das eleições municipais, que já estavam previstas no AI-11, para 14 de agosto de 1969. O AI-16 convocou o Congresso Nacional que estava em recesso desde o AI-5 para a escolha do sucessor de Costa e Silva. Neste Ato, foi estabelecido que os candidatos militares não precisavam estar filiados a nenhum partido político para concorrer ao cargo de presidente. O último dos atos foi o AI-17, que autorizou a Junta Militar a transferir para a reserva, os militares que tivessem "atentado ou viessem a atentar contra a coesão das Forças Armadas" (HELLER, 1988). De 1964 até 1969, o Brasil teve 17 atos institucionais regulamentados e 104 Atos Complementares, uma média de um Ato Institucional a cada quatro meses.

O general Emílio Garrastazzu Médici, em 17 de outubro de 1969, deixou a liderança do Sistema Nacional de Informação (SNI) ${ }^{14}$ para assumir o governo.

\footnotetext{
14 O Serviço Nacional de Informações (SNI), foi criado pela lei $\mathrm{n}^{\circ} 4.341$ em 13 de junho de 1964, servia como uma verdadeira operação de informações e teve suas atividades espalhadas por todo o país. Segundo Maria Helena Moreira Alves, o Estado Militar definiu o seu quadro jurídico
} 
Este governo lutou ostensivamente contra organizações clandestinas e importantes líderes revolucionários foram mortos, como Marighella, Mário Alves, Câmara Ferreira, Lamarca e outros. Conforme a Arquidiocese de São Paulo,

Sob o lema "Segurança e Desenvolvimento", Médici dá início, em 30 de outubro de 1969, ao governo que representará o periodo mais absoluto de repressão das liberdades civis de nossa história republicana. Desenvolvese um aparato de "órgãos de segurança", com características de poder autônomo, que levará aos cárceres politicos milhares de cidadãos, transformando a tortura e $o$ assassinato numa rotina (1985, p.63).

O sucessor de Médici foi Ernesto Geisel, que alardeava a aplicação do projeto de "abertura politica" de forma lenta e gradual, para gerar condições para redemocratizar o Brasil. Neste período, houve um pequeno avanço da oposição, logo refreada, com o Decreto-lei que limitou a propaganda eleitoral e também criou os "senadores biônicos", senadores escolhidos pelo governo. De acordo com Irene de Arruda Ribeiro Cardoso (1990, p.109), o projeto de "distensão lenta, gradual e segura" não foi prontamente adotado por todos os setores do regime, considerando que houve uma intensificação dos casos de desaparecimentos. Entre setembro de 1973 e setembro de 1975, 32 pessoas desapareceram:

Esse longo processo de abertura controlada, com fluxos, em função de conflitos no interior das Forças Armadas e com os setores autônomos da repressão, passa por alguns episódios elucidativos: as mortes de Herzog (1975) e de Manoel Fiel Filho (1976) no DOI-CODI [Destacamentos de Operações de Informações - Centro de Operações de Defesa Interna] de São Paulo, que levam à demissão do General Ednardo [refere-se ao general Ednardo D'Avilla do comando do II Exército]; cassações de cinco deputados do MDB exigidas pelos setores duros, em função de suas

quando instaurou o Ato Institucional №1, porém a criação do SNI foi de fato a primeira aplicação legal da Doutrina de Segurança Nacional (1984, p.74). 
denúncias sobre a violação dos direitos humanos (1976); o massacre da Lapa (1976); o fechamento do Congresso e o pacote de abril de 1977; a demissão do Ministro do Exército Sylvio Frota (1977); a reforma constitucional de 1978 que abole o AI-5 E introduz o "Estado de Emergência" (CARDOSO, 1990, p.109).

Em 1979, o general João Baptista Figueiredo15 assumiu a presidência e continuou promovendo a abertura de forma lenta e gradual. Contudo, uma das ações mais relevantes do presidente Figueiredo foi a decretação da lei da Anistia ${ }^{16}$, que dava direito a todos os que haviam sido punidos pelo regime militar exilados no exterior a voltar para o Brasil. Dessa maneira, segundo Boris Fausto, o Estado tirou, das mãos da oposição, uma das principais bandeiras: a luta pela Anistia (2004, p.504). Esta lei, deveria ser ampla e recíproca, atendendo tanto aos militantes quanto aos torturadores, de acordo com Daniel Aarão Reis Filho:

Todos os crimes seriam absolvidos. De todos os lados, a sociedade, soberana e indulgente, concedia sua absolvição geral aos criminosos de uma guerra de que ela, a sociedade, não havia a rigor sequer participado (1999).

Foram devolvidos os direitos politicos àqueles que haviam sido cassados. Entretanto, a lei tinha suas limitações, do ponto de vista dos militantes, já que previa situações específicas que restringiam o direito à Anistia. Dentre várias restrições, a lei não concedia Anistia aos militantes de luta armada que haviam se envolvido com mortes de agentes da repressão; também não previa a libertação imediata de militantes condenados pelo crime de tentar reorganizar partido ilegal; os militares não seriam reintegrados às Forças Armadas, mas passariam a receber pagamento integral por aposentadoria. Em contrapartida, Marco Aurélio Vannucchi Leme de Mattos destaca como a lei atingia o outro lado:

\footnotetext{
15 General João Baptista Figueiredo foi chefe do Gabinete Militar no período do governo de Médici e era chefe do SNI no governo de Geisel.

16 Lei n-6.683, de 28 de agosto de 1979.
} 
(...) a lei continha um dispositivo que estabelecia o perdão aos agentes do Estado que haviam cometido torturas $e$ assassinatos de opositores do regime, impedindo que fossem julgados por estes crimes. Neste ponto, a lei correspondia aos anseios do aparato repressivo e era uma derrota para a oposição (2002, p.30).

Neste governo, ocorreu, também, o fim do bipartidarismo, que se deu com a extinção de Arena e MDB e criação de novos partidos, como o PDS, o PDT e o PT. No final do governo de João Baptista Figueiredo, a sociedade exigia eleições diretas para presidente, porém o governo militar impediu a implantação das eleições diretas e o governador de Minas Gerais, Tancredo Neves foi eleito indiretamente. No entanto, aquela seria a última eleição indireta para presidente. Com a morte de Tancredo, em 1985, o seu vice José Sarney assumiu a presidência e finalizou a transição do regime militar para o governo civil.

\section{Movimento Estudantil}

O Movimento Estudantil teve, durante o regime militar, grande representação nas lutas politicas e sociais. A sua participação pode ser notada desde antes do Golpe de 1964, por exemplo, quando a União Nacional dos Estudantes (UNE) uniu-se à "Resistência pela Legalidade" para apoiar o Presidente João Goulart, durante a crise de 1961, a manter-se no governo, além de apoiar as lutas pelas Reformas de Base.

A UNE da década de 1940 é retratada pela historiografia geralmente com certo saudosismo (POERNER, 1979, p.155). A entidade estudantil desenvolveu campanhas importantes, tais como a campanha pelo alistamento na FEB (Força Expedicionária Brasileira) para lutar nos campos de batalha na Itália; a campanha Pró-Aviões, na qual a UNE organizou a arrecadação de dinheiro para a compra de três aviões de treinamento e a organização de caravanas que percorreram o país, convidando os jovens brasileiros a participar da Guerra. A UNE também cooperou com a Campanha Pró-Banco de Sangue, para a arrecadação e estocagem de sangue para ser utilizado pelos feridos da Guerra. 
Segundo Poerner, até 1945, os estudantes participaram de várias atividades em favor da vitória dos países Aliados contra o nazi-fazismo internacional. Entretanto, assegurada a vitória dos Aliados, os estudantes voltaram-se totalmente para as questões nacionais e a partir de março envolveram-se na campanha iniciada pela democratização do País (1979, p.176).

No dia 5 de março daquele ano em Recife, os estudantes rompem com o Estado Novo, ao participarem do comício para a pró-candidatura do Brigadeiro Eduardo Gomes. Neste evento, a repressão violenta contra o Movimento Estudantil, determinada pelo Interventor Federal, resultou na morte do estudante Demócrito de Souza Filho. Assim,

$$
\begin{aligned}
& \text { Declarando guerra ao Governo, a UNE mobilizou } \\
& \text { estudantes, políticos e trabalhadores, para frustrar a } \\
& \text { chamada "União nacional" em torno de Vargas (POERNER, } \\
& \text { 1979, p.176). }
\end{aligned}
$$

Em 1946, a UNE sofreu um esvaziamento político e limitou-se às atividades assistencialistas, esvaziamento gerado, segundo Poerner, pela restauração democrática, já que o Movimento Estudantil estruturado na luta contra o Eixo e contra o Estado Novo, sofreu "uma perda de conteúdo politico, em razão de terem sido eliminados aqueles objetivos imediatos da luta" (1979, p.179).

No final dos anos 50, a UNE ampliou suas discussões em relação às reformas sociais e às reformas universitárias. O Movimento Estudantil começou a discutir de fato a Reforma Universitária no I Seminário de Reforma de Ensino, realizado na Sede da UNE em 1957. Momento, a partir do qual,

(...) começa a esboçar-se a preocupação com a transformação estrutural das instituições de ensino, com o debate em torno da Lei de Diretrizes de Bases (LDB) que introduz a pergunta: Universidade para quem? Sobrepondose a Universidade como ou para quê? No bojo dos debates em torno da $L D B$, principalmente na discussão escola pública versus escola privada (FÁVERO, 1994, p.25). 
A discussão em torno do Projeto de LDB intensificou-se principalmente a partir do I Seminário de Reforma Universitária (ISNRU), realizado entre 20 a 27 de maio de 1960, na Bahia. Os temas referenciados neste encontro foram: " $A$ reforma universitária", "A realidade brasileira" e "A universidade no Brasil". Deste Seminário, resultou o documento A Declaração da Bahia, considerada por Poerner como um documento de fase de transição, pois ainda faltava uma proposta política e pedagógica mais consistente (POERNER, 1979, p.190).

No período de 1956-1960, a UNE promoveu mobilizações de estudantes contra o aumento de preços, defesa do nacionalismo, orientação para posicionamento adverso às empresas estrangeiras e aos acordos militares do Brasil com os Estados Unidos e participou também, na Campanha de Defesa da Escola Pública (SANFELICE, 1986, p.17).

Em 1961, o Movimento Estudantil estava envolvido na mobilização direcionada para as questões da qualidade de ensino e da ausência de métodos democráticos na gestão da Universidade. Porém, com a renúncia de Jânio Quadros e a iminência de que o vice-presidente João Goulart não pudesse assumir o cargo da presidência da República, a UNE direcionou as suas reivindicações para apoiar Jango. $\mathrm{O}$ apoio da UNE ao vice-presidente João Goulart custou sua sede no Rio de Janeiro, que foi fechada pela polícia do governador Carlos Lacerda. Na presidência da UNE estava Aldo Arantes, que viajou, em agosto de 1961, para o Rio Grande do Sul para participar da Campanha da Legalidade, "que empolgou o País e garantiu a posse - constatada por setores militares e conservadores - do Vice-Presidente João Goulart" (POERNER, 1978, p.188).

Aldo Arantes era representante da organização católica no ME. Segundo Martins Filho, a escolha de um representante católico está ligada à participação da Juventude Universitária Católica $(J U C)^{17}$ em um processo de politização que

\footnotetext{
17 Era um movimento de universitários cristãos que fazia parte da Ação Católica Brasileira (ACB), juntamente com a Juventude Agrária Católica masculina e feminina (JAC E JACF). O método da JUC era o da Ação Católica especializada, o método "ver-julgar-agir", ou de "formação para ação", fundamento na Ação desenvolvida na França, Bélgica e Canadá pelo Padre Cardjin. Nos anos de 1960, o método abordava a questão de "revisão de vida", no qual havia um esforço por conciliar a pedagogia e a formação ativa dos militantes, com a formação do meio social em que viviam. Nos anos de 1960, a prática política se tornou intensa nos centros acadêmicos até a UNE: um jucista
} 
se traduziu na defesa das reformas na universidade e na ordem social brasileira (1987, p.42). Segundo Mendes, a JUC e a Juventude Estudantil Católica (JEC), associações civis pensadas como setores especializados da Ação Católica Brasileira - $A C B$, foram criadas por volta do ano de 1950, com o objetivo de difundir os ensinamentos da Igreja nas escolas e universidades (MENDES, 2007, p.10).

Porém, várias discussões começaram a fazer parte das atividades do meio universitário católico, como, em 1953, quando a JUC voltou-se contra a hierarquia católica, ao defender a escola pública e o ensino gratuito, indo contra a Igreja, que defendia o ensino religioso particular. Conforme Dias,

No início da década de 60, a JUC tornou-se força dirigente na União Nacional dos Estudantes, fazendo alianças com setores da esquerda Estudantil. O processo de radicalização do discurso e da prática dos militantes da JUC chocou-se com os limites tolerados pela hierarquia da Igreja Católica. As alianças com os comunistas, a defesa da escola pública, as referências à revolução e ao socialismo, tudo isso contribuía para a deterioração das relações (1999).

Em 1962, foi criada a Ação Popular (AP), composta por desistentes da JUC, que tinham interesses mais políticos. A AP teve grande participação no Movimento Estudantil, pois controlou a diretoria da UNE em sucessivas direções.

Na gestão de Aldo Arantes, ocorreu em Curitiba o II Seminário Nacional de Reforma Universitária da UNE (IISNRU), de 17 a 24 de março de 1962, que resultou em um documento denominado Carta do Paraná, contendo proposta mais concreta de reformulação da instituição acadêmica.

A Carta do Paraná se dividiu em três partes: "Fundamentação teórica da Reforma Universitária", "Análise crítica da Universidade brasileira" e "Síntese final: esquema tático de luta pela Reforma Universitária”. Como resultado deste Seminário, a ação mais imediata da UNE foi tentar conquistar a 
regulamentação da participação Estudantil nos órgãos de direção da Universidade. Esta participação foi reivindicada na base de um terço e deveria ser regulamentada pelos estatutos das Faculdades e Universidades, uma vez que já estava assegurada pela Lei de Diretrizes de Bases da Educação Nacional, Lei Federal 4.024, de 20 de novembro de 1961 (POERNER, 1978, p.195).

Os estatutos das Faculdades deveriam ser entregues até 27 de junho de 1962 para o Conselho Federal de Educação, contendo as alterações reivindicadas pela UNE. O dia $1^{\circ}$ de junho foi fixado como data-limite para o atendimento da reivindicação da participação de um terço e, como isto não aconteceu, a UNE mobilizou os estudantes para
(...) uma greve geral nacional, de amplitude inusitada até então, pois chegou, a certa altura, a paralisar a maior parte das 40 Universidades brasileiras da época (23 federais, 14 particulares e três estaduais), além de ser pontilhada por grandes manifestações públicas, entre elas a ocupação, pelos universitários do Rio, do Ministério da Educação, de onde só foram desalojados com a intervenção da Polícia do Exército (POERNER, 1978, p.196).

A greve do um terço, que reivindicava a participação de estudantes na proporção de um terço dos membros componentes da administração da Universidade, contribuiu para aumentar a consciência politica do estudante e para chamar a atenção da opinião pública. No Paraná, adotou-se a proporcionalidade de um terço de representação estudantil na composição dos seus órgãos colegiados. Porém, Poerner ressalta que a greve gerou certo desgaste das lideranças estudantis, o que resultou no enfraquecimento da atuação política estudantil (1978, p.197).

Durante os anos de 1961 e 1962, a UNE criou a UNE - Volante que levou por todo o país a discussão da reforma universitária e, também, criou o Centro Popular de Cultura (CPC) que divulgava o teatro e o cinema popular. Dessa forma,

(...) levou sua mensagem cultural a todas as capitais do País, onde plantou, assim, as sementes dos CPCs estaduais, como o da Bahia, foco de onde se erradicou, 
graças também a isso, o movimento de renovação da música popular brasileira (POERNER, 1978, p.199).

Ainda no ano de 1962 , foi realizado o $25^{\circ}$ Congresso Nacional dos Estudantes, que elegeu mais uma vez um líder Estudantil católico, Vinícius Caldeira Brant. Em 1963, A Une realizou o III Seminário Nacional da Reforma Universitária em Belo Horizonte, reafirmando as propostas da Carta do Paraná. Neste ano, foi realizado o 2o Congresso da UNE, que elegeu o paulista José Serra, também da AP, para a sua presidência.

Segundo Poerner, nos anos de 1963 e 1964, a UNE excedeu e engajouse em muitos movimentos, da reforma universitária à luta contra o apartheid na África do Sul. Porém, os principais objetivos da UNE situavam-se nas reformas de base e no fortalecimento da sua própria estrutura. Para José Serra, o principal problema naquele momento não foi a dispersão e sim a tensão, reflexo da crise econômico-social e política (SERRA, 1980).

A UNE participou de importante comício em 13 de março de 1964, no qual José Serra foi um dos oradores. Este comício foi liderado por João Goulart na Praça da República, em frente à estação da Central do Brasil (RJ). Nele, Jango anunciou a assinatura de dois decretos, um de desapropriação de terras improdutivas às margens de eixos rodoviários, de leitos de ferrovias, de açudes públicos federais e das áreas beneficiadas por obras de saneamento da União; o outro encampava as refinarias particulares de petróleo, fortalecendo o monopólio estatal (POERNER, 1978, p.201).

Entretanto, nem toda a sociedade civil apoiava as medidas do presidente João Goulart e, como resultado de um ambiente democrático, outros setores sociais organizaram-se para protestar contra o governo. Assim, algumas entidades femininas, como a União Cívica Feminina de São Paulo, organizaram a "Marcha da Família com Deus pela Liberdade", em São Paulo, no dia 19 de março de 1964, o que contribuiu para a desestabilização do governo e promoveu apoio para a intervenção militar, em 31 de março do mesmo ano (SESTINI, 2007, p.1).

Com a instauração do governo militar, foi desencadeada imediatamente a "Operação Limpeza". Como conseqüência direta para os estudantes, a UNE 
teve sua sede invadida, na Praia do Flamengo no Rio de Janeiro. Os estudantes foram alvos de uma grande ação repressora logo nos primeiros dias do golpe. Maria de Lourdes de Albuquerque Fávero, ao pesquisar os jornais da época, relatou a morte de dois estudantes, em Recife, durante as passeatas de protestos nos primeiros dias do golpe. Os periódicos da época faziam, também, menção ao fechamento de entidades de representação estudantil em Minas Gerais, os DCEs e a unidade da UNE. Sobre o Rio de Janeiro havia relatos do choque entre estudantes e os soldados da polícia nas proximidades da Faculdade de Direito (FÁVERO, 1994, p.48).

Várias instituições foram invadidas, como a Faculdade de Filosofia de São Paulo (USP) que quase foi totalmente destruída. A Universidade de Minas Gerais teve nomeado um reitor militar, porém, a oposição foi tão grande que o Ministro da Educação teve que voltar atrás e destituí-lo. Contudo, a pior intervenção aconteceu na Universidade de Brasília (UNB), que teve seu campus invadido por tropas policiais, com professores e todos os membros de organizações estudantis presos.

As entidades estudantis sofreram, também, golpes no campo administrativo jurídico. Em novembro de 1964, o governo Castelo Branco aprovou a Lei Suplicy, que previa a transformação dos antigos Centros Acadêmicos em Diretórios Acadêmicos, totalmente subordinados às direções das faculdades. Assim,

Se a repressão geral foi institucionalizada no País com o AI2, editado em 27 de outubro de 1965, em relação aos estudantes, o governo Castelo Branco promulgou a Lei $n^{\circ} 4.464$, de 9 de novembro de 1964, conhecida como Lei Suplicy, de autoria do então Ministro da Educação, Flávio Suplicy de Lacerda (FÁVERO, 1994, p.60).

Esta lei vetava aos órgãos de representação Estudantil qualquer manifestação ou propaganda de caráter político-partidário, além de proibir as greves.

Obedecendo à Lei Suplicy, as organizações estudantis de ensino superior deveriam ser constituídas por Diretórios Acadêmicos (DA) em cada 
estabelecimento de ensino superior; Diretório Central dos Estudantes (DCE), em cada universidade, Diretório Estadual dos Estudantes (DEE), em cada capital de estado, território ou Distrito Federal e o Diretório Nacional dos Estudantes (DNE), com sede na Capital Federal. Segundo Marc Von der Weid, o ponto positivo da Lei consistia na obrigatoriedade do voto dos universitários, nas eleições para o Diretório Acadêmico de sua Faculdade, o que os obrigava a participar de discussões para as eleições:

O programa do governo para as universidades podia assim ser debatido e criticado, de tal modo que nossa posição viuse enormemente reforçada (ALVES, 1984, p.68).

$\mathrm{Na}$ verdade, a Lei Suplicy serviu para reorganizar os estudantes depois do Golpe, indo além de seu objetivo inicial de "silenciar o Movimento Estudantil" e acabar com a participação política dos estudantes (POERNER, 1978, p.231).

Para Maria de Lourdes de Albuquerque Fávero, um dos motivos da rejeição à Lei Suplicy, por parte dos estudantes, deveu-se ao fato de que este dispositivo legal desfigurava a legitimidade da entidade Estudantil, ao criar órgãos contra a vontade dos estudantes com atuação limitada. Esta lei limitava o direito de autonomia, de organização interna, de livre manifestação de pensamento e de associação (FÁVERO, 1994).

O primeiro Congresso da UNE, realizado após o golpe militar ocorreu em julho de 1965, tendo como principal tema o repúdio à Lei Suplicy. A UNE organizou, no dia 16 de agosto, o Dia Nacional de Repúdio à Política do Ministro da Educação e, no mesmo ano, 92,5\% dos estudantes manifestaram-se contra a Lei Suplicy em um plebiscito estudantil nacional (MARTINS FILHO, 1987, p.95).

No dia 17 de dezembro de 1965, a UNE foi extinta por um decreto-lei que revogou o Decreto-lei n-4. 105, de 11 de fevereiro de 1942, que a reconhecia como entidade coordenadora e representativa dos corpos discentes dos estabelecimentos de ensino superior do país.

Após o Movimento Estudantil passar por uma breve desarticulação, em 1966, os estudantes organizaram importantes passeatas, principalmente contra os acordos MEC-USAID. 
Os acordos MEC-USAID consistiam em projeto de reforma universitária proposto pelo Governo e inspirado no modelo privatizado norte-americano de ensino universitário. A reforma universitária seria efetuada sob a direção e coordenação de comissões de planejamento criadas nos termos dos acordos. Estas comissões eram compostas por técnicos escolhidos pela agência americana que destinava verbas e auxílio técnico para projetos de desenvolvimento educacional. Estes técnicos estabeleceriam diretrizes para a política educacional, a educação agrícola e a publicação de livros-texto. Os acordos originaram protestos por serem considerados uma ameaça para a autonomia universitária. Na opinião de Pellegrini,

A análise integral do primeiro acordo MEC-USAID, referente a assessoria para modernização da administração universitária, leva-nos a confirmar a existência da mentalidade empresarialista e a pretensão, por parte do órgão norte americano, de envolver a educação brasileira em todos os niveis. As recomendações incidem no funcionamento da estrutura administrativa, no planejamento dos cursos, no treinamento de professores $e$ técnicos, além de interferir no conteúdo geral dos cursos, através do controle de publicações e da distribuição de livros didáticos - na sua maioria, de autores americanos (1998, p.108).

Segundo José Luís Sanfelice, os acordos MEC-USAID foram objeto de críticas, porque refletiam a incompetência, por parte do Brasil, ao aceitar tal intervenção americana, sendo equivalente a um "atestado de dependência cultural". Existiam, entretanto, opiniões favoráveis aos acordos, pois, para algumas pessoas os "técnicos brasileiros não eram capazes de realizar a contento tal tarefa, que se tornara imperiosa" (1986, p.135).

Apesar de oficialmente extinta, a UNE continuava atuando na ilegalidade em 1966. Neste ano, realizou o XXVIII Congresso no porão da Igreja de São Francisco de Assis, em Belo Horizonte. Setembro de 1966 foi marcado por muitas manifestações pelo $\mathrm{ME}$. Foram tantas as manifestações importantes, que este período ficou conhecido como "Setembrada". A primeira 
manifestação foi o Congresso clandestino da UNE-UEE, em São Bernardo do Campo, no qual foram presos 178 estudantes. Em resposta à repressão policial exercida em São Paulo, o Movimento Estudantil do Rio de Janeiro organizou uma manifestação de protesto e, em represália, 20 mil policiais e soldados atacaram com violência a manifestação. No dia 22 de setembro, foi decretado o "Dia Nacional de Luta contra a Ditadura" (MARTINS FILHO, 1987, p.101).

No Rio de Janeiro, a ação policial reprimiu um grupo de dois mil estudantes de forma brutal e violenta. Os estudantes foram cercados no interior do prédio da Faculdade Nacional de Medicina, na Praia Vermelha, e foram espancados enquanto familiares e a imprensa esperavam do lado de fora. Segundo João Roberto Martins Filho,
A saida, formou-se um "corredor polonês", com novas $e$ agora visiveis violências contra os estudantes presos. Os carissimos equipamentos da escola foram totalmente destruidos; houve inúmeros feridos. Posteriormente, ouviram-se denúncias de violências sexuais contra os estudantes (MARTINS FILHO, 1987, p.101).

Em 28 de fevereiro de 1967, o governo instaurou o Decreto-lei 22818 (Decreto - Aragão), mais uma medida que atingiu diretamente o setor estudantil, como aponta o seu enunciado: "Reformula a organização da representação estudantil e dá outras providências”. O texto regulamenta a manutenção dos órgãos de representação dos estudantes do âmbito do ensino superior. Dessa maneira, o governo proibiu as entidades estudantis de funcionarem como associações civis e tentou, mais uma vez, a exemplo da Lei Suplicy, organizar e controlar as atividades da militância estudantil. A respeito das duas leis que tentaram restringir as articulações estudantis, Rafael Hagemeyer destaca a rejeição e reação dos estudantes paranaenses:

Com a indicação de Suplicy Lacerda - o "carrasco dos estudantes" para a reitoria da Universidade Federal do Paraná, a UPE abre imediatamente campanha contra a sua nomeação. Afinal, a lei 4.464, de 9/11/1964 - a "Lei

\footnotetext{
18 Decreto Lei №228, de 28 de fevereiro de 1967 - Ministro Raymundo Moniz de Aragão.
} 
Suplicy" - foi repudiada por todas as organizações estudantis em nivel estadual e nacional. Graças ao boicote dos estudantes, as organizações "pelegas" atreladas ao Ministério da Educação não tiveram apoio, à exceção do Diretório Estadual gaúcho, que funcionou até a reconstrução da UNE, em 1974. Mesmo com o chamado "decreto Aragão", que proibiu as entidades também como associações civis, as UEEs e a UNE continuariam existindo na clandestinidade até 1968 (HAGEMEYER, 198, p.98).

Em setembro de 1967, foi realizado o XXIX Congresso, em Valinhos (SP), onde foi elaborada a Carta Politica da UNE, que apresentou uma reflexão dos problemas nacionais, internacionais, buscando estabelecer um programa de ação. Em relação ao contexto nacional, a UNE discutiu o acordo MECUSAID; a internacionalização da Amazônia; o decreto que proibia greves estudantis; o Decreto-Aragão e a militarização dos médicos, farmacêuticos, dentistas e veterinários. A Carta Política procurava definir o papel do movimento estudantil e suas relações com a luta geral, que poderia ser uma aliança operário-camponesa-estudantil. Identificava a luta do trabalhador e do estudante como luta politica. A luta reivindicatória, segundo a Carta Politica, deveria ser empregada continuamente porque assim ela conseguiria ter seu valor e serviria de sustentação da luta política. A respeito do contexto internacional, foram abordadas as lutas de libertação nacional dos povos subdesenvolvidos e a reação do imperialismo através de golpes militares na Ásia, África e América Latina. Nesse congresso foi anunciada a "Semana de Solidariedade ao Povo do Vietnã”.

De acordo com o líder estudantil gaúcho Nilton Santos (1980), o XXIX Congresso pode ser considerado como um marco na história da UNE pós-64, pois até aquele momento somente os setores avançados dos estudantes tinham se envolvido com a mobilização do $\mathrm{ME}$, sem conseguir adesão significativa da massa estudantil. Por outro lado, José Luis Sanfelice e João Roberto Martins Filho apresentam de outras perspectivas a amplitude de temas abordados pela entidade estudantil a partir daquele momento. Nas palavras de Sanfelice, 
O avanço que havia ocorrido pós-64 era o rompimento com a política reformista dominante até então, mas sem conseguir resolver o problema da articulação das lutas específicas dos estudantes com as lutas politicas mais gerais e sem resolver o problema da direção politica do movimento (1986, p.139).

Concordando com esta visão, Martins Filho afirma que:

(...) a UNE nos anos de 1965 e 1966 voltou-se basicamente contra a estratégia repressiva do Estado, deixando para segundo plano as reivindicações educacionais (1987, p.123).

Segundo Maria Ribeiro do Valle, o presidente Artur da Costa e Silva iniciou seu governo, em 1967, com promessas de "redemocratização", tais como abertura do sistema político-partidário e, até, um diálogo com trabalhadores e estudante (1999, p.38). Entretanto, o governo logo colocou limites à "abertura" universitária: "O movimento estudantil viveu com mais intensidade que qualquer outro setor a oscilação entre “dialogo” e repressão” (MARTINS FILHO 1987, p.134).

Durante os anos de 1965 a 1968, houve a diminuição dos recursos do Ministério da Educação para o ensino superior, o que gerou "um congelamento na oferta de vagas nas faculdades, enquanto que a procura aumentava drasticamente". Esta situação foi chamada de "excedentes", mobilizando estudantes e suas famílias em vários protestos contra a atuação do Governo (RIDENTI, 1993, p.128).

\section{Movimento Estudantil em 1968}

No dia 2 de janeiro de 1968, o presidente Costa e Silva baixou decreto que criou comissão especial para formulação de nova política governamental para os estudantes, chefiada pelo Coronel Meira Matos, da Secretaria Geral do Conselho de Segurança. A partir desse momento,

O Ministério da Educação [estaria], subordinado a este órgão, fato que explicita a disposição do governo para a "militarização" do problema Estudantil (VALLE, 1999, p. 40). 
De acordo com Maria Ribeiro do Valle, o presidente Costa e Silva já não se mostrava tão disposto à redemocratização, o clima era de incertezas políticas e havia rumores da instauração de mais um Ato Institucional ou, até mesmo, da preparação de novo golpe (1999, p. 40). Em 28 de março, a tensão política e social que rondava o país eclodiu com o assassinato do estudante Edson Luís de Lima Souto, morto pela polícia com um tiro no peito durante o choque contra estudantes que participavam de uma manifestação contra o aumento do preço da refeição e a favor de obras de melhoria no restaurante Calabouço, considerado o "centro de fermentação política do $M E$ antes mesmo do golpe de 64" (Valle, 1999, p. 81).

Desde então, as manifestações estudantis espalharam-se pelo país com grande intensidade, ocorrendo 26 grandes passeatas em 15 capitais de estados. A morte do estudante Edson Luís "deflagrou uma seqüência de manifestações de massa em todo o país, que se propagava como rastilho de pólvora" (ARQUIDIOCESE DE SÃO PAULO, 1985c, p.196).

O enterro de Edson Luís foi acompanhado de grande mobilização popular e concentrou mais de 50 mil pessoas. Este acontecimento desencadeou várias passeatas e comícios contra a violência policial, obtendo como resposta mais repressão policial. Com a morte de Edson Luís, como será verificado nas fontes documentais desta pesquisa, os estudantes optaram pelo enfrentamento e, de acordo com Maria Ribeiro do Valle, a "violência passa a ser respondida com violência" (VALLE, 1999, p.53). Poerner descreve o momento:

Quando o corpo baixou à sepultura, as mais de $50 \mathrm{mil}$ pessoas que lograram acesso ao interior da necrópole ouviram o solene juramento prestado por milhares de jovens: - "Neste luto, começou a luta" Era sinal de que a até então maior manifestação popular de protesto pós-abril de 64 teria seqüência (1979, p.295).

No dia $1^{\circ}$ de abril, aniversário do golpe de 64 , foi realizada passeata organizada por uma comissão popular formada no dia do velório de Edson Luís. O governo estadual respondeu com repressão policial e o federal acionou o I Exército, já que o próprio governador Negrão de Lima reconheceu que o 
dispositivo de segurança tornou-se ineficaz contra as manifestações violentas que colocavam em risco a ordem pública (VALLE, 1999, p.56).

A passeata do dia 1 de abril deflagrou grande choque entre estudantes e a polícia do Rio de Janeiro, resultando em 2 mortes, 60 populares e 39 soldados feridos, 321 presos e a ocupação da cidade por tropas federais do Exército, da Marinha e da Aeronáutica.

A missa de sétimo dia de Edson Luís foi realizada na Igreja da Candelária (Rio de Janeiro), já que o Exército proibiu sua realização na rua, para evitar outra passeata e manifestação. Entretanto, a Polícia estava presente e, no final, investiu contra os manifestantes numa violenta repressão, atingindo homens e mulheres. Segundo o Jornal Correio da Manhã, os estudantes não tinham oferecido nenhum motivo para a presença e a medida repressiva da polícia:

\section{A Polícia Militar e o DOPS [Delegacia de Ordem Politica e Sociall investiram contra todos: as patas de cavalo, a chanfradas de sabre e espada, numa fúria selvagem, ensandecidos pelo desejo exclusivo de vendeta (Correio da Manhã, 5 de abril de 1968, p.6 apud VALLE, 1999, p.59).}

No dia 21 de junho, Vladimir Palmeira liderou uma grande manifestação Estudantil, no Rio de Janeiro, contra a violência do regime militar, seguida de quatro mortos, 58 feridos e mil presos. Este incidente ficou conhecido como "sexta-feira sangrenta".

O auge das manifestações estudantis daquele ano foi a "Marcha dos cem mil", em 25 de junho, no Rio de Janeiro, quando os participantes protestaram contra a política econômica e as inúmeras restrições às liberdades civis impostas desde 1964. Maria Ribeiro do Valle destaca que esta passeata foi pacífica, embora no discurso dos estudantes fosse ressaltado que a população deveria se organizar para utilizar a violência no "momento certo" contra o governo. O discurso do líder Estudantil Vladimir Palmeira incitou os manifestantes a reagir com violência contra o Estado militar, incentivou a educação das massas para a prática da violência e propôs a criação de um 
exército revolucionário (1999, p.115), visando assim tomar medidas drásticas para transformar o país.

Segundo Poerner, a passeata dos Cem Mil contribuiu para aumentar a insatisfação de muitos que lutavam pela "abertura democrática". Todo o clima gerado pelas manifestações fez com que jornalistas, editores, escritores, padres, parlamentares começassem a perder o medo de expor suas idéias e insatisfações (1978, p.299).

Em outubro de 1968, os estudantes sofreram um tremendo golpe no XXX Congresso da UNE, realizado em Ibiúna, que foi interditado logo no início, com quase 700 estudantes de várias regiões do país presos. Depois de autuados na Lei de Segurança Nacional, os estudantes foram liberados. No entanto, seus líderes, Vladimir Palmeira, José Dirceu, Luís Travassos e Jean-Marc, permaneceram presos. Estas prisões resultaram na instauração de processos criminais contra os participantes do Congresso. Segundo a Arquidiocese de São Paulo:

O principal exemplo desses processos volumosos é o que foi formado após a prisão de 693 estudantes de todo o país, no dia 12 de outubro de 1968, quando se encontravam reunidos numa propriedade rural de Ibiúna (SP), na tentativa de realizar o XXX Congresso da UNE. Subdividido mais tarde em várias parcelas, esse processo que chegou a ser julgado só no que se referia a alguns grupos de réus, funcionou como ameaça que obrigou centenas de estudantes a optarem pela vida clandestina na conjuntura de repressão que se intensificou com o Ato Institucional №5 (1985, p.136).

A prisão dos líderes estudantes no XXX Congresso da UNE, como será abordado posteriormente, resultou em várias passeatas e comícios, a maioria acabando em enfrentamentos com a polícia. Os estudantes também organizaram uma greve em repúdio à violência exercida no Congresso de Ibiúna, contando com o apoio de professores e de uma Comissão de mães de estudantes presos. 
Os estudantes do Congresso de Ibiúna foram enquadrados na Lei de Segurança Nacional, pois participaram de uma reunião proibida pela Lei. As manifestações de apoio aos estudantes contribuíram para a libertação da grande maioria dos participantes, que estavam qualificados e não tiveram a prisão preventiva decretada para "não aumentar a aflição de muitas famílias" (VALLE, 1999, p.212).

A mobilização estudantil, durante 1968, durou oito meses, desde o assassinato do estudante Edson Luís Lima Souto à invasão da Faculdade de Filosofia da USP pelos comandos do CCC - Mackenzie (Comando de Caça aos Comunistas) ${ }^{19}$ apoiado pela Polícia Militar de São Paulo, e à prisão em massa dos participantes do Congresso em Ibiúna (MORAES, 1989, p.136).

O "diálogo" entre movimento estudantil e o governo foi definitivamente abalado com a instauração do Ato Institucional no5. Se o AI-5 foi um ato para acabar com a oposição, a sua versão dentro da universidade foi traduzida pelo Decreto-lei $477^{20}$, que era extensivo a professores, funcionários e alunos. O Decreto prescreveu severas punições a quem, de acordo com a ótica do regime, utilizasse as dependências escolares para fins subversivos, incitasse a participação de paralisações, movimentos, passeatas, manifestações não autorizadas etc. (DIAS, 2000, p.33).

\footnotetext{
19 O enfrentamento entre os estudantes da Faculdade de Filosofia, Ciências e Letras da USP com os estudantes da Universidade Mackenzie, em 2 de outubro de 1968, ficou conhecido como "guerra da Maria Antonia". Maria Antonia era o endereço onde se situavam as duas unidades de ensino. Ironicamente, o Mackenzie ficava à esquerda e a "Filosofia" da USP, à direita da rua (MENDES, 2007, p.37). O conflito aconteceu quando um grupo de estudantes do Mackenzie confrontou-se com os estudantes da USP, que estavam organizando um "pedágio" na Rua Maria Antonia para arrecadar fundos para a realização do XXX Congresso da UNE.

"O que ficou registrado numa certa construção da memória daqueles acontecimentos como um mero conflito entre os estudantes da FFLCH da USP e os da Universidade Mackenzie foi de fato não um incidente, mas um ataque organizado e articulado, paramilitarmente, por integrantes do grupo à Caça dos Comunistas, o CCC, com antecedentes importantes desde 1964, relativos à Faculdade de Filosofia."

"Em 1964 foi depredado o Grêmio da FFCL, fato que se repetiu em 1967, por ocasião da eleição da UEE. Em agosto de 1968 o prédio principal da FFLC foi pichado com inscrições: "CCC voltou!", "Agora é pra valer", "Fora o comunismo", "CCC derrota o comunismo". Em 4 de setembro houve ainda ameaça de que bombas seriam atiradas ao prédio da faculdade, criando clima de intranqüilidade, sem que nada, entretanto ocorresse." (CARDOSO, I. DE A.R, 1998, p.33).

20 Definiu Infrações Disciplinares praticadas por professores, alunos, funcionários ou empregados de estabelecimentos de Ensino Público ou Particulares. (Decreto-lei 477 de 26 de fevereiro de 1969).
} 


\section{Fontes primárias e metodologia de análise}

Esta pesquisa tem por objetivo identificar as similaridades entre os estudantes processados pelo tribunal militar através da análise de documentos reunidos pelo Projeto Brasil: Nunca Mais (BNM)21, mantidos no Arquivo Edgard Leuenroth (AEL) da Universidade de Campinas (UNICAMP). Baseia-se, na análise de dois grupos de documentos pertencentes ao acervo do Projeto BNM. O primeiro grupo é a fonte classificatória do BNM nomeada de Projeto A Atingidos, com a relação dos processados pela Justiça Militar no período de 1964 a 1979. Quanto ao segundo grupo é formado por onze processos judiciais pertinentes aos anos de 1964 a 1968.

\section{Projeto Brasil: Nunca Mais (BNM)}

O acervo do Projeto BNM constitui na duplicação, levantamento e análise de $707^{22}$ processos políticos procedentes do Superior Tribunal Militar (STM) que transitaram pela Justiça Militar brasileira entre abril de 1964 e março de 1979.

A Anistia, decretada, em 1979, pelo presidente João Baptista Figueiredo, permitiu que os advogados, que representavam os presos e exilados, tivessem acesso aos processos, sob a custódia do Superior Tribunal Militar (STM) em Brasília, para preparação de petições de anistia. Assim que fossem retirados do STM, estes arquivos podiam permanecer por vinte e quatro horas com os advogados, o que permitiu que vários colaboradores do Projeto BNM fizessem fotocópias dos processos judiciais dos arquivos do próprio STM, estabelecendo assim as bases para um estudo incontestável sobre a tortura no Brasil (WESCHLER, 1990, p.24). Em decorrência da ação dos colaboradores, após três anos, o Projeto BNM reuniu em seu acervo a cópia de processos judiciais que foram originalmente arquivados na sede do Superior Tribunal

\footnotetext{
${ }^{21}$ Para a explicação a respeito do Projeto Brasil Nunca Mais (BNM) foi utilizado: ARQUIDIOCESE DE SÃO PAULO. Projeto Brasil Nunca Mais (Tomo II). São Paulo: Arquidiocese de São Paulo, 1985, p.22.

22 Os pesquisadores do Projeto BNM desenvolveram várias metodologias de classificação com o objetivo de possibilitar a manipulação dos 707 processos judiciais. No entanto, devido a problemas logísticos no decorrer da execução do Projeto foi considerado para efeitos estatísticos o universo documental de 695 processos judiciais.
} 
Militar (STM) e arrolaram mais de 17.000 pessoas durante os anos do governo militar. De acordo com pesquisadores do Projeto BNM,

"Foram obtidas, por inúmeros caminhos, cópias de 707 processos completos e dezenas de outros incompletos, num total que ultrapassou 1 milhão de páginas imediatamente microfilmadas em duas vias, para que uma pudesse ser guardada, sem riscos, fora do país." (ARQUIDIOCESE DE SÃO PAULO, 1985, p.22).

A realização do Projeto contou o auxílio financeiro do Conselho Mundial de Igrejas (CMI) e a liderança do Cardeal Arcebispo de São Paulo, na época Dom Paulo Evaristo Arns e do Presbiteriano Jaime Wright.

Os processos judiciais foram analisados por uma equipe, com supervisão metodológica da Professora Dra. Ana Maria de Almeida Camargo, do Departamento de História da Universidade de São Paulo (AQUINO, 2004, p.53). Esse estudo consta em um relatório de seis Tomos, divididos em 12 volumes, nomeado de Projeto $A^{23}$, também disponível no acervo do AEL (UNICAMP).

Os 707 processos judiciais foram distribuídos em três grupos pelos pesquisadores do BNM, conforme mostra o Gráfico 1. O grupo organizações de esquerda contém o maior número de processos, reunindo 446 processos que dizem respeito às atividades de organizações partidárias clandestinas. No grupo segmento social foram agrupados 177 processos, que abordam as atividades de acusados que representavam setores sociais facilmente identificáveis, tais como militares, sindicalistas, políticos, jornalistas, religiosos e estudantes. No grupo outras atividades estão 84 processos que não tratam diretamente da ação de organizações de esquerda e os envolvidos não são facilmente classificáveis no item segmento social, "porque constituiam uma mescla de pessoas com origens $e$ indoles muito diferenciadas” (MITRA ARQUIDIOCESANA, 1987, p.119 e p. 239).

\footnotetext{
23 A versão resumida do Projeto A produziu o livro Brasil: Nunca Mais (Vozes, 1985), elaborado por Ricardo Kotscho e Frei Betto (AQUINO, 2004, P.53).
} 


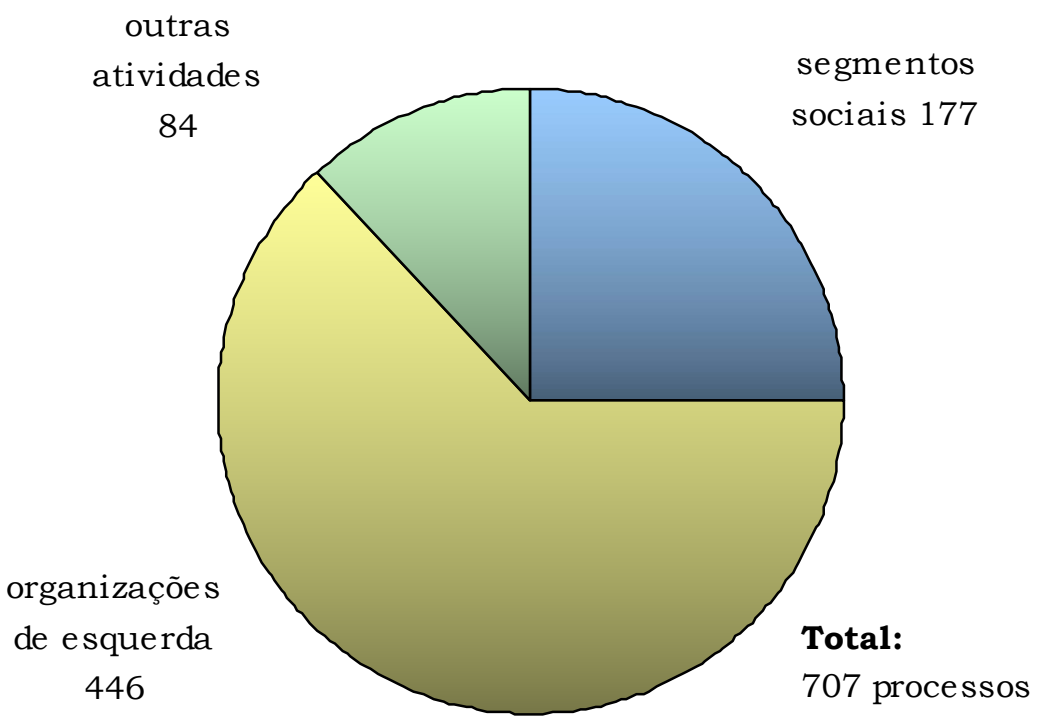

Gráfico 1: Classificação dos Processos proposta pelo Projeto BNM

O Gráfico 2 demonstra que 383 processos, ou seja, 54\% do total de processos do acervo BNM, continham pelo menos um estudante. Dentre esses 383 processos, 51 dos 177 pertencentes à categoria segmento social foram classificados pelos analistas do BNM como de atividades do setor estudantil, em que investigaram atividades de mobilizações reivindicatórias vinculadas ao ensino com suas tradicionais atividades de propaganda política (MITRA ARQUIDIOCESANA, 1987, p.119). Abstraindo-se os 51 processos do setor estudantil, os denunciados estavam distribuídos em 332 processos que faziam parte dos grupos classificados de segmento social, organizações de esquerda e outras atividades. 


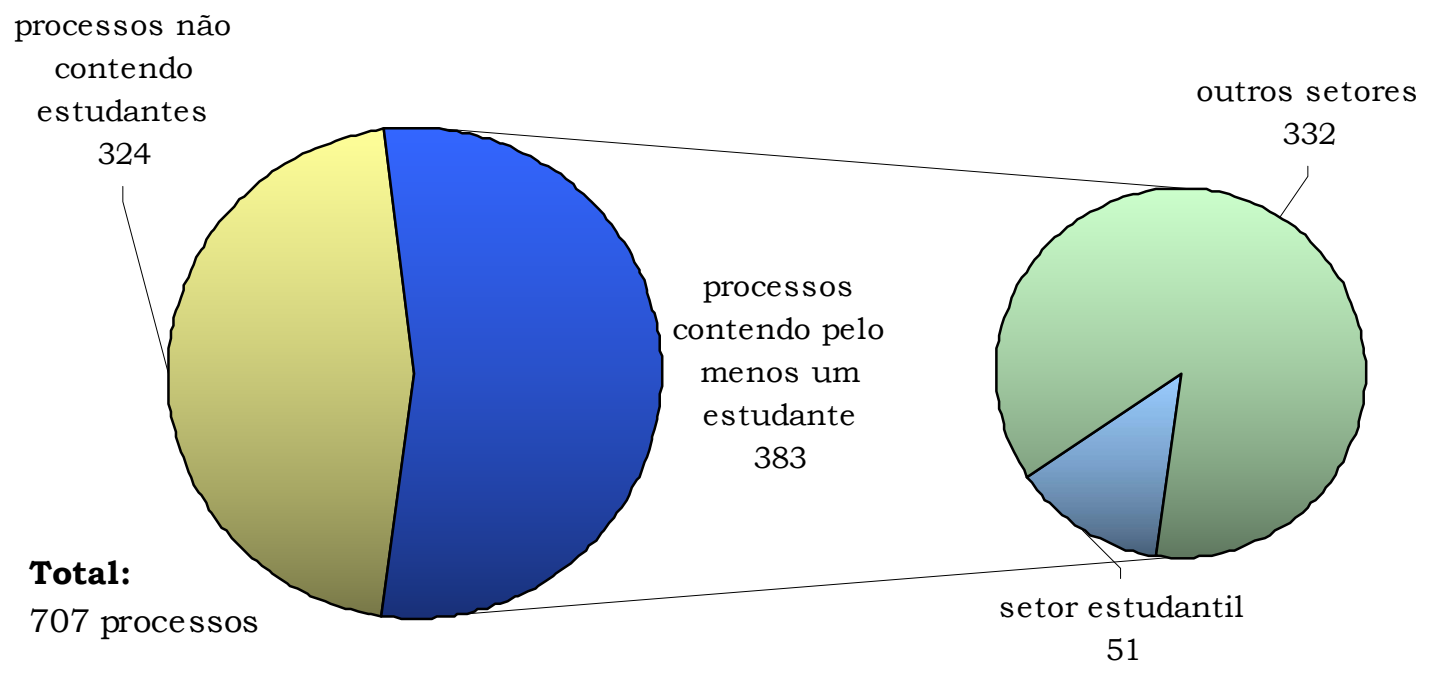

Gráfico 2: Presença de estudantes nos Processos Judiciais

Primeiramente foi utilizada a fonte classificatória geral dos atingidos, listada no Tomo II, volume 2 do Projeto $A$, onde estão relacionadas as informações pessoais dos 17.420 atingidos com a numeração dos respectivos processos judiciais. A relação de Atingidos foi dividida em quatro categorias mostradas no Gráfico 3, ou seja, denunciados ${ }^{24}$, indiciados, testemunhas e declarantes.

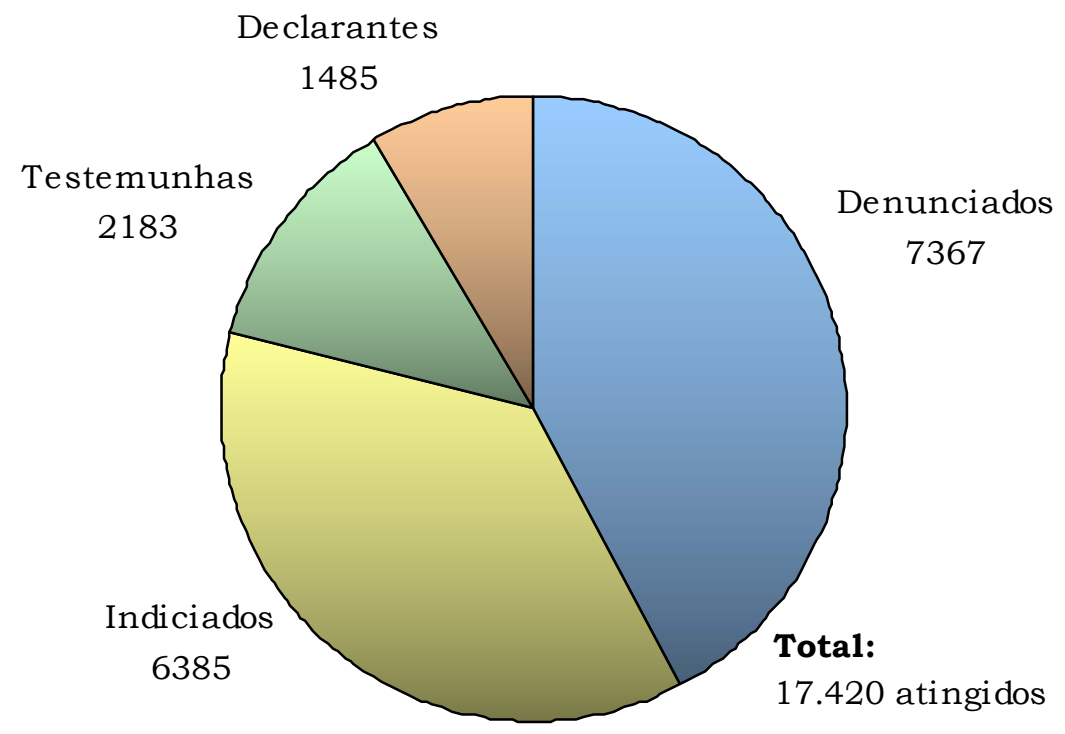

Gráfico 3: Representação da Fonte Documental - Projeto A - Atingidos

${ }^{24} \mathrm{O}$ acusado é chamado de indiciado na fase do inquérito policial e denunciado na fase judicial. 
Dentre os 7.367 denunciados, 1.691 se declararam estudantes, conforme mostra o Gráfico 4. Estes 1.691 registros de estudantes denunciados, que perfazem $23 \%$ do total de denunciados, constituem o referencial principal da caracterização dos atingidos nesta pesquisa.

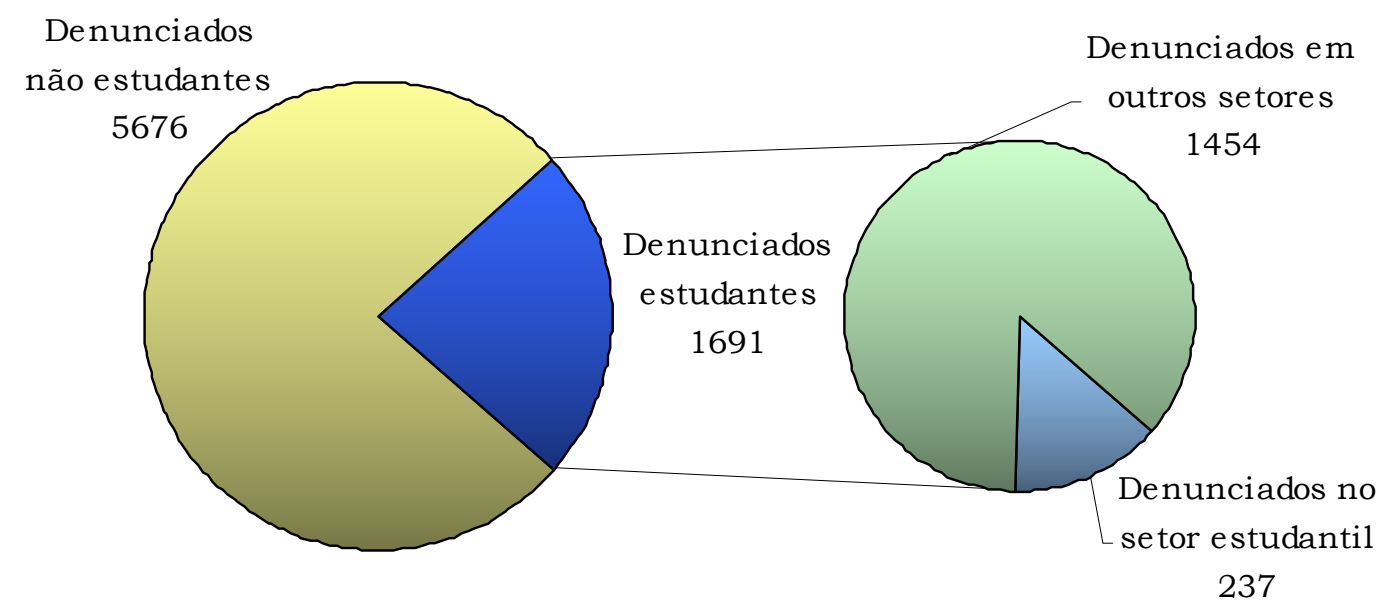

Total:

7.367 denunciados

Gráfico 4: Estudantes denunciados no Projeto BNM

O registro de 1.691 corresponde a 1.143 estudantes (Gráfico 5), dado que alguns dos réus foram processados em mais de um processo. A partir deste momento, adota-se o termo denunciados para indicar o total de denúncias de estudantes observadas nos processos, incluindo a eventual repetição de nomes, ao passo que o termo estudantes refere-se aos indivíduos propriamente ditos, sem considerar a repetição de nomes. 


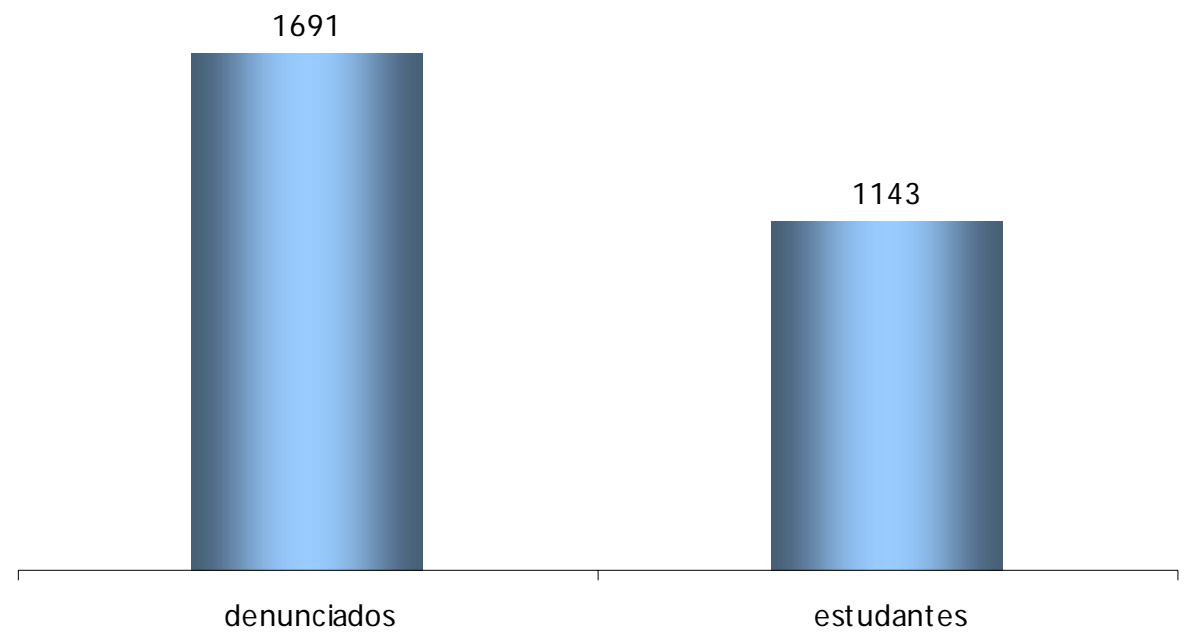

Gráfico 5: Estudantes denunciados em todo o universo do Projeto BNM

Os registros dos 1691 denunciados foram digitados em planilha do Microsoft Excel, constituindo a base para as análises apresentadas neste e no capítulo 1. Utilizando as ferramentas de tabela dinâmica disponíveis no Excel, foi possivel obter, a partir da lista de denunciados, a lista de estudantes e o número de processos em que cada um dos mesmos aparece como denunciado. Em seguida, foi analisada a questão da idade e sexo de todos os estudantes por faixas etárias. Foi possivel, também, identificar os denunciados distribuídos nos processos judiciais segundo a atividade subversiva classificada pelo Projeto BNM. Outro dado importante foi identificar, cronologicamente, o estudante que iniciou a militância em atividades classificadas como do setor estudantil e depois continuou em atividades classificadas como de organizações de esquerda e de outras atividades.

\section{Fonte 2: Onze processos judiciais}

Após a sistematização referente aos dados contidos no Projeto $A$, esse estudo aprofunda-se na análise das especificidades de determinados processos judiciais. Devido ao caráter monográfico deste estudo, aliado à limitação de tempo, parte do qual é dedicada ao processo inicial de conhecimento e entendimento da fonte documental, optou-se pela análise de onze processos judiciais, selecionados dentre os 51 processos classificados como de atividade do setor estudantil. Nesses 11 processos, foram, também, identificados estudantes denunciados em mais de um processo, de tal forma que o total de 
224 estudantes arrolados nos processos em questão, corresponde a 237 denunciados, como demonstrado no Gráfico 6.

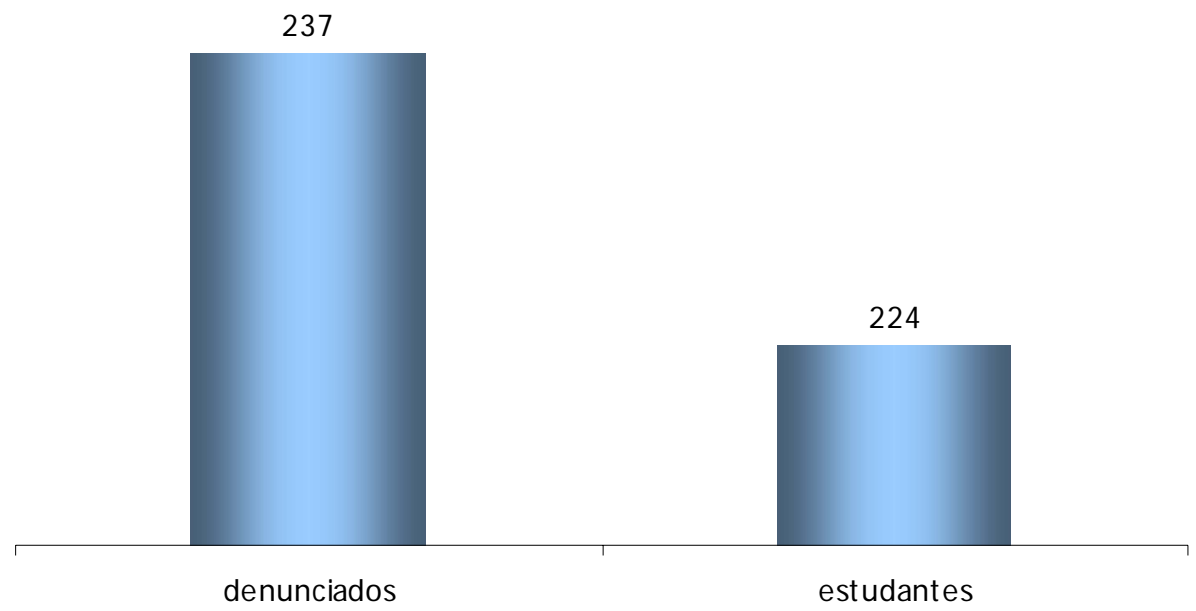

Gráfico 6: Estudantes denunciados nos Processos do Setor Estudantil

Para a seleção dos onze processos foi utilizada a listagem disponivel no QUADRO DE DISTRIBUIÇÃO CRONOLÓGICA E GEOGRÁFICA DOS PROCESSOS POR SETORES (ARQUIDIOCESE DE SÃO PAULO, 1985b, p.258). Desta maneira, os processos selecionados, além de corresponderem exclusivamente ao setor estudantil, também compreendem o mesmo recorte temporal, ao mesmo tempo em que estão agrupados em relação aos estados onde foram cometidos os delitos. Conseqüentemente, a base documental desta pesquisa foi composta pelos processos listados no Quadro 1, de acordo com o ano de instauração.

Um aspecto relevante da seleção dos processos é o recorte temporal 1964 a 1968 - período que o governo lançou bases para a institucionalização do regime militar. Algumas das principais ações, como mencionado, foram a promulgação da Constituição de 1967, que possibilitou uma centralização ainda maior de poder no Executivo, facultando-lhe o direito de legislar a respeito de questões da Segurança Nacional (ALVES, 1984); a edição da lei de Segurança Nacional (DL no314/1967) que ampliou o conceito de crime político. 
Em 1968, no final deste primeiro período ${ }^{25}$, o governo decretou o AI-5, um dos atos mais draconianos do regime, que fortaleceu o aparato de repressão do Estado.

Quadro 1: Relação dos onze processos BNMs

\begin{tabular}{cc|c}
\hline \multicolumn{2}{c|}{ Processos BNM } & Ano \\
\hline BNM & 623 & $(1966)$ \\
BNM & 163 & $(1967)$ \\
BNM & 489 & $(1967)$ \\
BNM & 695 & $(1967)$ \\
BNM & 5 & $(1968)$ \\
BNM & 354 & $(1968)$ \\
BNM & 401 & $(1968)$ \\
BNM & 408 & $(1968)$ \\
BNM & 429 & $(1968)$ \\
BNM & 535 & $(1968)$ \\
BNM & 690 & $(1968)$ \\
\hline
\end{tabular}

Com relação à quantidade de processos judiciais selecionados, esta pesquisa baseia-se nos critérios de seleção de Vilma Antunes Maciel e Marco Aurélio Vannucchi Leme de Mattos. Na primeira pesquisa, foram analisados nove processos judiciais contra os militantes da organização armada Vanguarda

25 Segundo Marco Aurélio Vannucchi Leme de Mattos e Walter Cruz Swensson Júnior, o regime militar vigente no Brasil durante o período de 1964 a 1985 pode ser dividido em três ciclos repressivos: o primeiro, abrangendo 1964-1968, o segundo, os anos de 1969-1974, e o terceiro, o período de 1974-1985.

O primeiro ciclo corresponde ao período em que o governou promoveu a "Operação Limpeza", perseguindo todos aqueles ligados à situação política anterior ao governo de 1964. No segundo ciclo (1969-1974), as Forças Armadas se envolveram definitivamente na repressão e eliminação de grupos clandestinos de esquerda. O último ciclo (1975-1985) abrange o governo de Ernesto Geisel, marcado pela tentativa de processo de abertura politica entre avanços e retrocessos. O projeto de Geisel previa o menor uso da força repressiva contra as oposições, contudo, Geisel enfrentou uma ala dentro do governo contra o projeto de liberação. Mesmo com esse projeto de distensão, o governo promoveu várias ações repressivas contra organizações comunistas e, também, ocorreram atentados terroristas de direita executados por agentes de segurança integrantes de grupos paramilitares. Neste ciclo, foi decretada a Lei de Anistia (MATTOS, SWENSSON Jr., 2005, p. 87-91).

O Projeto BNM dividiu o universo da pesquisa nos mesmos três períodos, atendendo às especificidades da legislação vigente no regime militar. Em relação aos três períodos, o projeto BNM contabilizou no primeiro período, 2.375 denunciados; de 1969 até 1974 foram 4.748 e de 1975 a 1979 (fim dos processos) foram 244 denunciados (ARQUIDIOCESE DE SÃO PAULO, 1985e, p.2). 
Popular Revolucionária (VPR), referente ao período de 1969 a 1971. Já na segunda, a análise concentra-se em sete processos contra os integrantes da Ação Libertadora Nacional (ALN), referentes aos anos de 1969 a 1979. Das explicações quanto à escolha e uso dos processos, destacam-se as palavras dos próprios pesquisadores:

Mesmo sendo uma pequena amostra do total de processos instaurados pela Justiça Militar, pode-se afirmar que por meio dela se pode ter uma visão do que foi a ação da Justiça, porque a maioria compreende as principais ações, semelhantes às dos que não foram analisados, e também contém um grande número de réus. Outro aspecto é o próprio ritual dos processos, que obedece aos mesmos procedimentos, como mesmos são os juizes, procuradores $e$ advogados (MACIEL, 2006, p.42).

É preciso observar a homogeneidade do corpus documental usado neste trabalho. Os processos da Justiça Militar (e da Justiça Comum também) são bastante parecidos entre si, pois existem regras, estabelecidas pelo costume e pelas leis, para a produção da maioria das peças processuais (MATTOS, 2002, p.39).

Dessa maneira, a seleção de onze processos judiciais é amparada no método utilizado nestas duas pesquisas e, através de uma análise qualitativa desta amostra do acervo documental do Projeto BNM, pretende-se evidenciar como funcionou a Justiça Militar no período de 1964 a 1968.

Para trabalhar com fontes judiciais certos cuidados foram necessários, principalmente com relação ao momento histórico de elaboração dos documentos. Em primeiro lugar, impõe-se uma atenção toda especial ao contexto em que foram produzidos os processos (PRIORI, 1994). Nos processos pertencentes ao Projeto BNM é essencial o estudo preliminar da instauração do regime militar e do processo lento de organização dos estudantes para enfrentar a truculência do governo militar instaurado em 1964. Outro aspecto considerado é o destacado por Silvia Helena Zanirato Martins: 


\begin{abstract}
Estes (os processos criminais) são depositários de informações valiosas que possibilitam apreender os valores, crenças e esperanças dos personagens envolvidos. Longe de ser portador de um discurso neutro ou mesmo objetivo, esse tipo de documento é antes o resultado de uma ação claramente desequilibrada e mediada por filtros muitas vezes deformantes. Apesar desses filtros intermediários $e$ deformantes, tal fonte não constitui um documento menos "objetivo" do que outro. Como todo registro, é antes um código que precisa ser decifrado (Martins, 1998).
\end{abstract}

As informações e códigos dos processos do Projeto BNM são totalmente relacionadas à argumentação e uso da Lei de Segurança Nacional e seu caráter repressivo. Ainda sob a contribuição do trabalho de Silvia Helena Zanirato Martins (1998), enfatiza-se que esta pesquisa não procura desvendar o que realmente aconteceu, pois os autos policiais e judiciais traduzem não a verdade, mas a batalha que se instaura para produzir uma verdade destinada a punir, graduar a pena ou absolver. Portanto, a análise dos processos judiciais demonstra como o governo repressivo utiliza-se de códigos legislativos cada vez mais articulados para restringir qualquer tipo de contra reação da sociedade.

A análise desses documentos, extraídos do Projeto BNM, além de basear-se nos trabalhos de Vilma Antunes Maciel (2206) e Marco Aurélio Vannucchi Leme de Mattos (2002), também recorre aos métodos dos pesquisadores Marcelo Ridenti (1993), Maria Aparecida de Aquino (1994) e Tadeu Antônio Dix Silva (2007) que pesquisaram as fontes documentais do Projeto BNM. Marcelo Ridenti pesquisou todos os processos relacionados às organizações de esquerda reunidas no Projeto BNM. A pesquisadora Maria Aparecida de Aquino analisou quinze processos-crimes instaurados contra jornalistas que, haviam praticado, conforme o entendimento do Estado, atividades que constituíram crimes contra a Segurança Nacional. Tadeu Antônio Dix Silva analisa três processos judiciais arquivados no BNM para narrar a história da Ala Vermelha, organização de esquerda que surgiu como dissidência do Partido Comunista do Brasil (PC do B). 
O procedimento metodológico utilizado na análise dos onze processos consistiu em primeiramente, identificar e separar os autos processuais em duas fases, a fase do Inquérito Policial Militar (IPM) e a da instância judiciária. De acordo com Boris Fausto (1984), o processo penal como documento abarca dois "acontecimentos" diversos: aquele que produziu a quebra da norma legal e um outro instaurado a partir da atuação do aparelho repressivo. Este último, reconstrói um acontecimento para estabelecer a "verdade" da qual resultará a punição ou absolvição de alguém (FAUSTO, 1984, p.21). Em seguida, foi utilizado o relatório do delegado, que faz parte da fase do Inquérito, em que é feita a caracterização dos réus. Esta atividade consiste na seleção dos estudantes arrolados nos processos selecionados para esta pesquisa. A partir desta primeira seleção é possivel determinar idade, curso, local de estudo e qual atividade atribuída ao estudante foi considerada subversiva pelo Estado. Em terceiro, na documentação correspondente à fase judicial, são analisadas as partes dos processos.

Nesta fase, foram identificados os artigos incriminatórios e qual o embasamento legal que possibilitou a acusação. A seguir, foram avaliadas razões e argumentação do Estado para criminalizar os estudantes e justificar o pedido de prisão. $\mathrm{Na}$ fase judicial também foram consideradas as alegações da Promotoria e da Defesa, tanto para condenar, quanto para absolver os réus. Por último, avaliamos o Acórdão ${ }^{26}$, no qual foi possivel identificar as razões do juiz para confirmar, tanto a absolvição, quanto a condenação.

Segundo Boris Fausto, na sua materialidade, cada processo é um produto artesanal, com fisionomia própria, revelada no rosto dos autos, na letra caprichada ou indecifrável do escrivão, na forma de traçar uma linha que inutiliza páginas em branco. "A peça artesanal contém uma rede de signos que se impõe à primeira vista, antes mesmo de uma leitura mais cuidadosa do discurso" (FAUSTO, 1984, p.20).

\footnotetext{
26 Acórdão é a decisão final proferida sobre um processo por um tribunal superior, que funciona como paradigma para solucionar casos análogos. Os acórdãos devem ser redigidos, datados e assinados pelos juízes.
} 
Após a leitura detalhada dos processos, os agentes envolvidos deixaram de ser unicamente dados ou nomes, passaram a ser protagonistas de uma história particular dentro de um acontecimento maior. Carlos Bacellar, ao refletir sobre a relação do historiador com a fonte documental, diz que "com o passar dos dias, ganha-se familiaridade, ou mesmo, certa intimidade, com escrivães ou personagens que se repetem nos papeis” (BACELLAR, 2005, p24). 


\section{Caracterização do Estudante}

Nesta etapa do trabalho pretende-se analisar, de maneira quantitativa, as duas fontes documentais para a caracterização dos estudantes denunciados nos processos judiciais, tanto no universo total do Projeto BNM, quanto nos onze processos reunidos para esta pesquisa. Inicialmente, são apresentados os resultados da análise da fonte documental Projeto A - Atingidos, seguida da análise da segunda fonte documental.

Este tipo de análise contribui para entender a atuação de alguns setores sociais contestadores ao governo instaurado em 1964, que contaram com massiva participação do movimento estudantil e tiveram no seu quadro, em média, $50 \%$ ou $60 \%$ dos militantes com menos de 25 anos de idade (RIDENTI, 1993, p.119)27. Vários estudos abordam a questão da juventude relacionada com a participação política ${ }^{28}$, sobretudo aquela nascida da condição estudantil. Dessa maneira, os conceitos juventude e estudante estão frequentemente relacionados, embora o estudante universitário possa enquadrar-se em outras faixas etárias além daquelas em que os jovens são comumente classificados, segundo a literatura. Conseqüentemente, abordar como o conceito de juventude interfere na pesquisa relacionada à atuação estudantil é uma ferramenta importante para elaborar a caracterização do estudante denunciado no Projeto BNM.

Primeiramente, é apresentado um breve comentário das pesquisas de Hermes Zaneti (2001), Luís Antonio Groppo (2000), Marialice Foracchi (1972) e Melissa de Mattos Pimenta (2001), que trabalham a questão da juventude, esta que pode ser considerada "epistemologicamente imprecisa" (MAUGER, 1994, apud SPOSITO, 2001).

\footnotetext{
${ }^{27}$ Marcelo Ridenti refere-se em sua pesquisa aos processos do Projeto BNM agrupados na categoria organizações de esquerda que reuniu 446 processos judiciais (1993).

28 Paulo Cesar Rodrigues Carrano relacionou alguns estudos que tratam do tema Jovem e Participação Política: (ANDRADE, 1994; CAVALARI, 1987; FARIA, 1996; FERNANDES, 1996; HAYASHI, 1986, 1995; JUSTINA SILVA, 1987; PEREIRA 1991; SANFELICE, 1985; SILVA, 1998 e VALLE, 1999) In: CARRANO, Paulo Cesar Rodrigues. Jovens e Participação Política. In: SPÓSITO, M. P. (Org.) Juventude e Escolarização. 1 ed. Brasília: MEC/Inepe/Comped, 2002, v. 1, p. 185202.
} 
Após identificar as implicações do conceito de juventude, passa-se para apreciação dos resultados da análise das duas fontes documentais. Da primeira fonte são abordadas as questões de idade, sexo, trabalho e tipificação da atividade subversiva.

Em relação à segunda fonte é feita a caracterização de 72 denunciados nos onze processos judiciais. Nesta parte do estudo, foi possivel a análise de outras informações disponiveis somente a partir da leitura dos autos dos processos, tais como estado civil e cursos freqüentados pelos denunciados.

\subsection{Juventude}

A sociedade ocidental tem utilizado a combinação de critérios etárionaturais e critérios sociais para forjar a definição de juventude e atender às realidades das sociedades modernas, sendo a adoção de faixas etárias um dos instrumentos mais comuns para esta definição. A Organização Internacional da Juventude define os limites etários entre 15 e 24 anos, Stoetzel define juventude no Japão do pós-guerra entre 15 e 25 anos, enquanto a WHO/OPAS entre 10 e 20 anos (ZANETI, 2001, p, 27). Em relação ao Estatuto da Criança e do Adolescente (ECA) ${ }^{29}$, considera-se adolescente a pessoa entre doze e dezoito anos de idade.

Para Pierre Bourdieu a "juventude é apenas uma palavra", que se presta a todo tipo de manipulação, porque é uma categoria que tende a ser definida biologicamente, ignorando-se que "as divisões entre idades são arbitrárias" e "objeto de disputas em todas as sociedades" (1983, p.113). De acordo com Alexandre Barbosa Pereira, a Juventude definida por Pierre Bourdieu só faria sentindo no contraste entre os mais novos e os mais velhos. Ou seja, Bourdieu compreende a categoria juventude sempre dentro de um critério etário que não faz sentido isoladamente, pois seria sempre na contraposição que esta se definiria (PEREIRA, p.1, 2007).

Por outro lado, Mario Margulis e Marcelo Urresti (1996) criticam a concepção de Pierre Bourdieu com o texto intitulado "A juventude é mais que

29 Estatuto da Criança e do Adolescente - LEI №.8.069, DE 13 DE JULHO DE 1990. 
uma palavra" (1996). Esses autores consideram que o conceito de juventude supera a categorização por idade e como portadora de características uniformes. Para Margulis e Urresti (1996), a discussão feita por Bourdieu leva à percepção da juventude como "mero signo", como "uma construção cultural desgarrada de outras condições”. Conforme estes autores, a noção, do modo como ela é definida por Bourdieu, é desvinculada de seus condicionantes históricos e materiais (MARGULIS, \& URRESTI, 1996, apud PEREIRA, 2007, p.1).

Apesar da ampla utilização do critério de faixas etárias para definir juventude, é preciso considerar outros aspectos além dos biológicos, como os condicionamentos socioeconômico e cultural, que têm fundamental relevância para entender a juventude. Em oposição ao critério de faixa etária, Marialice Foracchi (1972) e, mais tarde, autores como Luís Antonio Groppo (2000), Hermes Zaneti (2001), Melissa de Mattos Pimenta (2001), entre outros, conceituam a juventude como uma categoria social, o que significa entender que a juventude está além da sua classificação etária. A juventude não pode ser definida por critérios etários, de modo que haja limites restritos para definir quando o indivíduo é jovem mediante seu pertencimento às categorias de 14 a 20 anos, 17 a 25 anos ou 15 a 21 anos.

A juventude é uma representação sócio-cultural forjada dentro de grupos sociais ou pelos próprios jovens, para significar uma série de comportamentos a eles atribuídos na sociedade. Dessa maneira, a juventude é produto da sociedade em que está inserida e das relações que mantém com instituições desta sociedade (GROPPO, 2000). O comportamento do jovem dentro da sociedade deve ser interpretado como um comportamento de transição que depende da situação em que o mesmo está inserido e não somente das condições biopsicológicas relacionadas à idade. A despeito de todas essas recomendações, Luís Antonio Groppo reconhece que a definição de juventude dificilmente está livre do seu referencial etário, e de certa maneira, a combinação entre critério etário e critério sócio-cultural está sempre subjacente e expressa nas pesquisas (GROPPO, 2000). 
Hermes Zaneti (2001) destaca que a condição juvenil pode superar a condição de estudante, porque o jovem apresenta um potencial de ação transformadora e revolucionária que até pode ser estimulada pela sua condição de estudante. Entretanto, para este autor, quando o estudante extrapola as dimensões da universidade para fazer parte de um processo revolucionário, indica que essa atitude revolucionária está ligada à sua condição de jovem e não à sua condição de estudante. Dessa maneira, para Zaneti, o estudante que quebra o círculo vicioso universitário e atua em outros contextos está sendo impulsionado pela sua condição juvenil e não pela condição de estudante (p.183).

De acordo com Luiz Carlos Bresser-Pereira (2006), um dos principais motivos para a revolta estudantil é o descomprometimento dos estudantes com as estruturas econômicas e políticas vigentes na sociedade e da sua capacidade de analisar os problemas sociais através de um idealismo inerente à realidade juvenil. Para esse autor, as reivindicações estudantis estão relacionadas com a condição juvenil, combinadas também com o ambiente acadêmico, tal como confirmamos em suas palavras:

Todo homem possui anseios de liberdade e justiça. No entanto, é na juventude que esses ideais são mais poderosos. Depois quando cada um sai da universidade $e$ se vê na contingência de enfrentar a vida prática, trabalhar, sustentar sua familia, progredir em sua carreira, esses ideais começam a perder sua força. O jovem é obrigado a toda sorte de compromissos, de concessões. Esses compromissos e concessões vão sendo racionalizados, justificados (BRESSER-PEREIRA, 2006, p.57).

Esses tipos de concepções compreendem que a juventude é o momento de transitoriedade, no qual o indivíduo passa a buscar a sua autonomia, num mundo social cujas normas, regras e valores, não foram completamente definidos. Portanto, os jovens incorporaram uma capacidade de mudança, e até mesmo militância - impulsionada pela sua posição transitória e "desapegada" que ocupa no "mundo social". 
Comentar as implicações do conceito de juventude é importante, primeiro porque autores, como Hermes Zanetti (2001) e Luiz Carlos BresserPereira (2006), consideram a condição de ser jovem o fator essencial que impulsiona o militante para a ação revolucionaria no movimento estudantil. Segundo porque as mobilizações dos estudantes jovens durante os anos de regime militar geraram condições para o aparecimento de importantes lideranças políticas e culturais atuantes na nossa atual sociedade. Sendo assim, desvendar os significados e vivências sociais da juventude é importante para o entendimento da própria sociedade moderna em diversos aspectos, como a arte, o lazer, as relações cotidianas, a politica, etc. (GROPPO, 2000).

As afirmações de Zaneti e Bresser-Pereira reforçam a importância da condição juvenil como um dos fatores fundamentais para o impulso revolucionário, levantando questões sobre a necessidade ou não de identificar as razões dominantes que levam um militante a envolver-se em mobilizações políticas e, na prática revolucionária. A militância do movimento estudantil estaria relacionada à condição de ser jovem ou ser estudante? Ou, ainda, teria a confluência entre ambas as condições colaborado decisivamente para a atitude revolucionária dos estudantes arrolados nos processos judiciais? A maioria dos estudantes denunciados era jovem?

O caminho metodológico adotado para responder às indagações aqui formuladas é a análise da fonte documental com os dados referentes à idade dos militantes estudantis. Com esse estudo é possível demonstrar se a maioria dos estudantes denunciados enquadrava-se em faixas etárias comumente consideradas para a juventude, no momento da denúncia do delito. Conseqüentemente, essa análise contribui para a elaboração de um perfil dos estudantes arrolados nos processos judiciais e, passamos, junto com Tadeu Antônio Dix Silva (2007), também, a responder à indagação formulada por Maria Aparecida de Aquino (1994): "Afinal, quem eram esses militantes?" (AQUINO, apud SILVA, 2007, p.298). 


\subsection{Caracterização dos Estudantes do Projeto A - Atingidos}

Para determinar a importância da condição juventude na militância estudantil, a primeira análise efetuada é a que determina a idade entre os denunciados. Dessa maneira, neste primeiro item é identificada a faixa etária predominante dos denunciados nos processos agrupados como os de organizações de esquerda, os do segmento social e os de atividades incriminatórias.

Em seguida, são apresentadas duas concepções que defendem a condição estudantil como fator fundamental para a militância. No item referente à caracterização do sexo dos estudantes, foi verificado qual gênero tem maior predominância. Primeiro, foi analisada a predominância de gênero no universo total de 1.143 estudantes, em segundo, entre os 224 estudantes somente no setor estudantil. Dessa maneira, foi possivel comparar os dois universos. Em terceiro, foram distribuídos os estudantes por sexo em relação às faixas etárias.

No item 1.2.4 (Estudante trabalhador) é discutida a ocorrência do estudante trabalhador nas fontes do BNM e as concepções de Marialice Foracchi (1972) a respeito do tema. Em seguida, são demonstrados quantos denunciados foram relacionados por processos judiciais e a ocorrência de estudantes em processos diferentes ao do setor estudantil, permitindo identificar a participação dos estudantes em todo o universo documental do Projeto BNM.

\subsubsection{Idade}

Do total de 1691 registros observados nos processos, em 28 deles não consta a idade do denunciado. Sendo assim, o Quadro 2 mostra a distribuição de idades de 1663 registros dos denunciados com idade conhecida, excluindo os 28 registros mencionados. Deste total, 64\% dos denunciados possuem idade entre 21 e 25 anos, contra 20\% com idade inferior a 21 anos. O aspecto relevante desses resultados é que, em 16\% dos registros, os estudantes 
militantes possuiam mais do que 25 anos, idade superior aos vários limites etários propostos por organizações que tratam da questão da Juventude ${ }^{30}$.

Quadro 2: Estudantes denunciados em todos os Processos Judiciais do BNM distribuídos por faixa etária

\begin{tabular}{ccc}
\hline Idade & Total & Porcentagem* \\
\hline$<21$ & 335 & $20 \%$ \\
21 a 25 & 1057 & $64 \%$ \\
$>25$ & 271 & $16 \%$ \\
\hline total & 1663 & $100 \%$ \\
\hline Sem idade declarada & 28 & $2 \%$ \\
\hline Total Geral & $\mathbf{1 6 9 1}$ & \\
\hline
\end{tabular}

* Percentuais não consideram 28 registros sem informações

O Quadro 3 demonstra que, dentre os registros dos 237 denunciados, somente nos 51 processos nomeados como do setor estudantil, 19\% tinham até 21 anos, enquanto $81 \%$ tinham 21 anos ou mais. Parte significativa dos estudantes criminalizados já tinha alcançado a faixa etária superior a 22 anos. Observa-se, neste caso, que $11 \%$ dos estudantes denunciados enquadram-se na faixa etária acima dos 25 anos.

Quadro 3: Estudantes denunciados nos Processos Judiciais do Setor Estudantil distribuídos por faixa etária

\begin{tabular}{ccc}
\hline Idade & Total & Porcentagem* \\
\hline$<21$ & 46 & $19 \%$ \\
21 a 25 & 165 & $70 \%$ \\
$>25$ & 26 & $11 \%$ \\
\hline Total & $\mathbf{2 3 7}$ & $\mathbf{1 0 0 \%}$ \\
\hline
\end{tabular}

Daniel Aarão Reis Filho (1989, p.165) considera o universo de 15.242 31 pessoas relacionadas em todos os processos do BNM para sua análise da população distribuída em faixa etária nos processos judiciais (abstraindo registros sem informação de idade). No que se refere aos atingidos nesse universo, Reis Filho apontou que 15\% tinham até 21 anos, enquanto que 43\%

\footnotetext{
30 Organização Internacional da Juventude, WHO/OPAS, Estatuto da Criança e do Adolescente (ECA).

31 Daniel Aarão Reis Filho considerou o quadro 27 do Projeto: Brasil Nunca Mais que trata da Caracterização Geral Atingida por Faixa Etária (denunciados + indiciados + testemunhas + declarantes). (Arquidiocese de São Paulo. Arquidiocese de São Paulo, 1985 d, p.340)
} 
tinham entre 22 a 30 anos de idade. Por outro lado, Marcelo Ridenti (1993, p.119), trabalha com os dados dos processos nomeados pelo BNM de organizações de esquerda, avaliando que $34,5 \%$ dos 2.465 denunciados $^{32}$ com idade conhecida, também, tinham superado a faixa etária dos 22 anos, contra $15,4 \%$ dos que faziam parte da faixa etária de até 21 anos e 48,2\% de todos os denunciados nas organizações de esquerda tinham mais de 26 anos. No trabalho de Tadeu Antônio Dix Silva (2007, p.293) a questão da faixa etária restringe-se aos integrantes da Ala Vermelha, em São Paulo, que na sua maioria, também, já tinham ultrapassado a faixa etária de 22 anos $(43,8 \%)$ do total de 64 arrolados em três processos. Os resultados obtidos por esses autores, que consideram denunciados estudantes e não estudantes, são confirmados pelos resultados obtidos nesta pesquisa, em que $20 \%$ do total dos estudantes denunciados possuem menos de 21 anos de idade contra $80 \%$ dos estudantes que possuíam idade igual e acima de 21 anos.

A análise da faixa etária de todos os estudantes denunciados comprova que o fator juventude não pode ser considerado uma condição predominante para a ação militante estudantil. Se fosse considerada a idade de 24 anos, idade comum para a conclusão da Graduação, ou mesmo a idade de 21 anos, como idades limite para o fim da juventude, obter-se-ia respectivamente a ocorrência de $38 \%$ e $80 \%$ dos estudantes denunciados com idade igual e superior a essas faixas etárias, o que não deveria ocorrer, se a condição juvenil fosse preponderante para a militância estudantil.

\subsubsection{Condição estudantil}

Neste item são apresentadas algumas concepções que defendem a condição de ser estudante como um fator essencial para a militância estudantil. Essa abordagem tem sido fundamentada no comportamento político dos estudantes e no seu caráter revolucionário, podendo ser agrupados em duas tendências. A primeira, apresenta o estudante sempre na condição de disponibilidade de engajamento político para a defesa das causas sociais. A

\footnotetext{
32 Marcelo Ridenti considera o universo de 4.124 denunciados nas Organizações de Esquerda, excluídos os nomes repetidos do total de 7.367 .
} 
segunda, encara a atuação reivindicatória do estudante como um trampolim social de suas aspirações de classe de origem (REZENDE 2003).

A primeira tendência vincula a participação política e social do estudante fundamentalmente à defesa das classes menos favorecidas. Segundo João Roberto Martins Filho (1987), esta visão do estudante como o agente defensor das camadas menos favorecidas não passou de mitologia estudantil e deve ser superada a idéia de que os estudantes, no Brasil, sempre estiveram ao lado do povo brasileiro em todas as lutas. Os universitários não devem ser representados como indivíduos imunes aos condicionamentos dados por sua classe de origem e como portadores de uma ampla liberdade social de ação.

Daniel Aarão Reis Filho também concorda que a militância estudantil não está predestinada, por decreto insondável da Providência Divina, a assumir um papel questionador, ou reformista e muito mesmo revolucionário, na história do país, ou de qualquer lugar do mundo:

Aliás, pouco antes da instauração da ditadura, em 1964, a direita liberal ganhara, no voto, o controle da União Metropolitana dos Estudantes, entidade de coordenação do movimento estudantil, o que se refletiria na agressiva ação de muitos estudantes que participaram ativamente da frente social e politica que instaurou a ditadura (1998, p.29).

A segunda tendência apontada por Darcilene Sena Rezende, atende à proposição de João Roberto Martins Filho e Marialice Foracchi, considerando fundamental a inserção do estudante em relação a sua classe social de origem. Nesta concepção, a atuação do estudante não é considerada como a de defensora das camadas mais pobres e sim, uma atuação política que visa gerar condições para o estudante ascender socialmente, mesmo sendo incompatível com os interesses de sua classe social de origem. O estudante procura, através das reivindicações do movimento estudantil, superar os obstáculos que limitam sua ascensão como classe. 
A partir desta concepção da importância da origem de classe, Marialice Foracchi33 $^{33}$ (1972) constrói o conceito de categoria social "estudante", no qual o estudante é um agente social de transitoriedade das camadas médias e portavoz de sua ideologia de ascensão. Alguns dos processos de construção da categoria social estudante podem ser articulados em três níveis. Primeiro, destaca-se a possibilidade da ascensão social através da educação; em segundo é analisado o comportamento do estudante quanto a sua relação e vínculos com a classe média e em terceiro, é preciso avaliar as relações interpessoais do estudante com os adultos provedores de sua educação.

Marialice Foracchi destaca a importância desta relação de dependência do estudante com a família. O estudante que não trabalha precisa corresponder às expectativas da família, no entanto, ele também tem a oportunidade de alcançar vôos mais altos, em nível profissional, através da sua condição de ser somente estudante. Desta maneira, forja-se uma relação de ambigüidade entre família e estudante, havendo momentos em que a subordinação do jovem pode ser completa, e outros em que a passividade pode ser superada pelas vontades do estudante, de tal forma que alguns conflitos ficam evidentes na relação. Por outro lado, segundo a autora, o estudante trabalhador não tem a mesma relação de dependência com a família provedora, todavia, e sua responsabilidade de manutenção faz com que não tenha a oportunidade de dedicação total à carreira, limitando sua capacidade de desenvolvimento profissional.

Nas concepções de João Roberto Martins Filho e Marialice Foracchi, que priorizam a questão da origem de classe, existe o risco de entender o engajamento dos estudantes em manifestações políticas como atitudes oportunistas e individuais. No entanto, a ação do estudante, no âmbito coletivo das reivindicações, supera os anseios particulares para a formatação de um projeto maior. Portanto, ao invés de se apoiar nas concepções estabelecidas por Martins Filho e Foracchi, esta pesquisa corrobora as concepções de Daniel

\footnotetext{
33 Os comentários das obras de Marialice Foracchi foram baseados no coeso trabalho de Maria Helena Oliva Augusto que recupera as principais discussões presentes na produção desta autora. Augusto, M.H.O. Retomada de um legado Intelectual. Marialice Foracchi e a sociologia da juventude. In: Revista Tempo Social. Revista de Sociologia da Usp. São Paulo: V. 7 №2, novembro de 2005, p.11- 33 .
} 
Aarão Reis Filho, que entende que os estudantes não são um todo monolítico, alheio às divisões políticas e regido pela sua adscrição de classe social de origem. Nas palavras do autor:

São [os estudantes] atravessados pelas questões que agitam a sociedade, e que não podem ser reduzidas à problemática da origem de classe. Pode parecer banal, mas contraria boa parte dos estudos sobre o assunto que não se privam de se referir ao movimento estudantil como se fosse um todo, sem fraturas e contradições internas, com sua ação rigidamente limitada pelas condições sociais (REIS FILHO, 1998, p.29).

Concordando com esta concepção, destaca-se a afirmação de Marcelo Ridenti, segundo a qual a militância estudantil é uma luta de caráter coletivo, esboça uma ruptura da ordem vigente e não se trata mais da tentativa isolada de ascensão social, através da educação, de indivíduos menos ou mais pobres (1993, p.144).

João Roberto Martins Filho e Marialice Foracchi reconhecem que há contradições e ambigüidades inerentes ao movimento estudantil, no entanto, esses autores apontam para a relação do estudante com sua classe de origem, a classe média ascendente, como o principal fator destas contradições. Nesta concepção, o estudante traz para sua realidade universitária os desvios da sua classe de origem. Contudo, concordamos com Ridenti que não nega a existência de contradições no movimento estudantil, mas alega que é necessário investigar a condição transitória do estudante entre sua classe de origem e a classe que ele busca alcançar para identificar estas contradições e ambigüidades. Segundo Ridenti, três momentos são fundamentais para compreender o universo estudantil universitário. O primeiro é quanto à origem do estudante, depois o período de transição na universidade e, em terceiro, o lugar que a sociedade promete ao futuro profissional diplomado (RIDENTI, p.141, 1993).

$\mathrm{Na}$ questão da origem há necessidade de reaver a afirmação de que todos os estudantes universitários faziam parte da classe média ascendente, pois como mencionado, havia estudantes que eram trabalhadores do período parcial e, até, integral para manter o próprio sustento e desta maneira, 
podemos facilmente apontá-los como integrantes da classe trabalhadora. Em seguida, a questão da situação de transição na universidade pode demonstrar que os estudantes faziam parte de uma camada em mobilidade social ascensional e, por último, há a questão da diversidade em relação ao destino profissional dos estudantes, sendo que alguns caminharam para o mercado de trabalho como integrantes da classe trabalhadora e outros para postos de destaque no mercado profissional.

Para Marcelo Ridenti um dos principais motivos para a mobilização dos estudantes durante o governo militar, foi a frustração das perspectivas criadas durante os governos populistas que geraria condições para ascensão social e a manifestação cultural e política:
Quaisquer que fossem as origens de classe dos universitários, eles estavam em sua maioria empenhados em levar adiante, para usar os temos caros a Foracchi, um projeto de carreira fortemente marcado por uma ideologia de ascensão social que poderia ser chamada de "pequeno- burguesa" (1993, p.145).

Havia um projeto de ascensão social, mas como mencionado, não era uma militância de caráter individual, era na verdade, o resultado da inconformidade de uma parcela dos estudantes, que de acordo com Marcelo Ridenti (1993), tinham consciência critica cultivada desde os anos do populismo, que não concordavam com o modelo político e econômico do regime militar. Além da busca da ascensão social através da educação, o estudante tem, dentro do peculiar espaço universitário, acesso a debates e formação de uma consciência crítica. O ambiente universitário torna-se propício para esta radicalização política do estudante através da convivência com grande número de jovens e com suas organizações e agremiações, que facilitam a mobilização e agitação política, especialmente quando se trata de oposição às autoridades estabelecidas (BRITTO, 1968).

Nesta concepção, tem total influência na atuação do estudante, o fato de ser um intelectual em formação com a consciência comprometida com a mudança radical e estrutural da sociedade (IANNI, 1968). Conseqüentemente, os desentendimentos entre o mundo acadêmico $\mathrm{e}$ as novas diretrizes 
educacionais do governo, durante o período militar, foram um dos motivos que fomentaram a insatisfação dos estudantes e contribuíram para sua organização e para o desenvolvimento de uma agenda de protestos que ia além de aspirações individuais.

Embora a insatisfação com a politica socioeconômica e o descontentamento com as tentativas de uma reforma universitária tenham atraído os estudantes para uma relação de afrontamento com o Estado repressivo, não é possível, nesta pesquisa, determinar se a condição estudantil foi o fator fundamental para a militância. O fato é que as fontes documentais foram selecionadas a partir da ocupação dos denunciados como estudantes, dessa maneira, toda a base documental analisada compreende o denunciado em sua condição estudantil. Para a verificação do fator predominante na militância dos denunciados seria necessário a ampliação da fonte documental, abrangendo todo o universo dos denunciados.

\subsubsection{Sexo}

Com relação ao sexo dos estudantes denunciados, observa-se que $82 \%$ da população estudantil relacionada em todos os processos do BNM pertencem ao sexo masculino e $18 \%$ ao sexo feminino. Uma proporção similar é observada entre os 51 processos do setor estudantil, ou seja, 89\% dos estudantes pertencentes ao sexo masculino e $12 \%$ ao sexo feminino. Esse padrão também é observado no Quadro 4, que representa o total da população relacionada pelo Projeto BNM, no qual $11 \%$ dos atingidos são do sexo feminino e $89 \%$ são do sexo masculino.

Quadro 4: Caracterização Geral da População Atingida por Sexo

\begin{tabular}{ccc}
\hline Sexo & Quantidade & Porcentagem \\
\hline Masculino & 15.454 & $89 \%$ \\
Feminino & 1.966 & $11 \%$ \\
\hline Total & $\mathbf{1 7 . 4 2 0}$ & $\mathbf{1 0 0 \%}$ \\
\hline
\end{tabular}

Fonte: ARQUIDIOCESE DE SÃO PAULO. Projeto Brasil Nunca Mais (Tomo II, Os Instrumentos de Pesquisa e a Fonte). São Paulo: Arquidiocese de São Paulo, 1985b, p.339.

A faixa etária que contém maior número de processados, entre 21 a 25 anos, também manteve a proporcionalidade de $82 \%$ de estudantes do sexo 
masculino e $18 \%$ de estudantes do sexo feminino. Como observado no Quadro 5 , esta mesma proporção entre homens e mulheres é verificada em todas as faixas etárias, com uma pequena alteração se considerados somente os estudantes com idade inferior a 18 anos, na qual se registra a proporcionalidade de $75 \%$ de estudantes do sexo masculino para $25 \%$ de estudantes do sexo feminino. Deve ser observado que essa diferença, no caso de militantes com idade inferior aos 18 anos, ocorre em virtude do pequeno número de estudantes contidos nesta categoria ( 8 pessoas, ou seja, menos do que $1 \%$ do total).

Considerando o pequeno número de estudantes menores de 18 anos, esta faixa etária foi incorporada à faixa etária que corresponde aos menores de 21 anos.

A concentração masculina entre os estudantes denunciados é proporcional aos índices apresentados por Daniel Aarão Reis Filho (1989, p.167), Marcelo Ridenti (1993, p.204) e Tadeu Antônio Dix Silva (2007, p.290) que também trabalharam com as fontes do Projeto BNM, no entanto, com olhar direcionado para outros agentes atingidos pela Justiça Militar. O número reduzido da participação feminina pode ser resultado da realidade da sociedade conservadora da década de sessenta. De acordo com Marcelo Ridenti, a maioria das mulheres ocupava posições submissas na política brasileira e seus lugares eram fundamentalmente os de "mães-esposas-donas-de-casa" (1993, p.198). Contudo, o importante desses dados é demonstrar a permanência da atuação feminina durante o regime militar. Em algumas situações ocorreu até o aumento desta proporção, como Daniel Aarão Reis Filho demonstrou, ao citar que em relação às vítimas de torturas, $21 \%$ eram do sexo feminino e $79 \%$ eram do sexo masculino (1989, p.167).

Quadro 5: Denunciados segundo sexo e faixa etária

\begin{tabular}{cccc}
\hline Idade & Feminino & Masculino & Percentual* \\
\hline$<21$ & $18 \%$ & $82 \%$ & $100 \%$ \\
21 a 25 & $18 \%$ & $82 \%$ & $100 \%$ \\
$>25$ & $15 \%$ & $85 \%$ & $100 \%$ \\
\hline total & $\mathbf{1 8 \%}$ & $\mathbf{8 2} \%$ & $\mathbf{1 0 0} \%$ \\
\hline * Percentuais não consideram 28 registros sem informaçōes
\end{tabular}


Outra perspectiva interessante que demonstra a participação feminina na militância é a observação de Tadeu Antônio Dix Silva em relação ao universo da Ala Vermelha. O autor informa que "as sete militantes [relacionadas nos processos judiciais] correspondem tão somente àquelas que caíram nas mãos do aparato repressivo e não representam o efetivo número de mulheres que militavam nessa organização" (2007, p.291). Essa reflexão pode ser aplicada para todo o universo do Projeto BNM e, de alguma maneira, reivindica que outras fontes documentais confirmem como se deu, de fato, a participação feminina na militância. Por exemplo, a pesquisa de Ruth Lima (1998), que apresenta depoimentos de quatro militantes, que tiveram papel de destaque no interior de suas Organizações/Partidos e que foram selecionadas em virtude de terem levado até às últimas conseqüências o projeto de luta armada.

\subsubsection{Estudante trabalhador}

Marialice Foracchi aponta a possibilidade da ocorrência do estudante trabalhador e do não trabalhador e suas implicações (AUGUSTO, 2005). Essa autora também abordou os conflitos geracionais, o caráter de transitoriedade da juventude e a construção do conceito de estudante como categoria social. Entretanto, a autora destaca, especificamente quanto ao estudante trabalhador, algumas peculiaridades que devem ser consideradas. A primeira, refere-se aos casos em que a família não pode manter totalmente o estudante somente nesta condição e o trabalho torna-se fundamental para a complementação do seu sustento. Nesta condição, os laços de dependência podem não se alterar de maneira significante, pois o estudante ainda é sustentando pela família. Outra situação é a do trabalhador estudante, na qual, o mesmo é responsável pela própria manutenção e da família, caso em que, o "trabalho mantém os vínculos entre o estudante e a familia" (FORACCHI, apud AUGUSTO, 2006, p.16). Isso supõe que a condição de trabalhador supera a de estudante e, segundo a autora, o comprometimento com os estudos e a carreira pode ficar em segundo plano nesta condição. 
Dos $1691^{34}$ estudantes relacionados do Projeto A, 11,6\% também foram classificados pelo menos em mais de um processo com uma ocupação diferente da de estudante, conforme mostra o Quadro 6. Por exemplo, o nome de Aton consta em 8 processos ${ }^{35}$ com atividades desde como estudante, auxiliar de escritório, bancário, jornalista, escriturário a jornalista e a sua idade variou entre 22 a 24 anos, o que demonstra que este estudante foi processado em diferentes momentos de sua vida acadêmica. Do total de 237 denunciados nos 51 processos do Setor Estudantil, 11,4\% declararam desempenhar outras atividades além de estudante: ator teatral, comerciante, funcionário público, médico, professor, operador de TV e vendedor.

\footnotetext{
34 Neste cálculo foi utilizado o número de ocorrência, pois em diferentes momentos da vida o estudante pode ter diferentes ocupações ou até mesmo duas simultaneamente.

35 BNM 7, BNM 22, BNM 27, BNM 100, BNM 258, BNM 597, BNM 631, BNM640.
} 
Quadro 6: Ocupação declarada pelos denunciados

\begin{tabular}{l|r}
\hline \multicolumn{1}{c|}{ OcuPAÇÃo } & TOTAL \\
\hline Advogado & 2 \\
Artesão & 1 \\
Ass.Social & 1 \\
Ator teatral & 7 \\
Bancário & 6 \\
Cabeleireira & 3 \\
Comerciante/Vendedor & 12 \\
Datilógrafo & 3 \\
Desempregado & 2 \\
Economista & 5 \\
Escriturário/ Auxiliar de Escritório & 7 \\
Estatístico & 1 \\
Funcionário Público & 9 \\
Industriário & 1 \\
Jornalista & 2 \\
Lavrador & 1 \\
Médico & 5 \\
Militar & 6 \\
Operário & 1 \\
Prendas Domésticas & 3 \\
Professor & 15 \\
Radialista/ Operador de TV & 2 \\
Sociólogo & 3 \\
Técnica Computação/Eletrônica & 2 \\
Militante & 5 \\
Estudante & 149 \\
NC & \\
\hline TotaL & \\
\hline & 169 \\
\hline
\end{tabular}

É importante destacar, dentre os 1.691 denunciados, a existência de 87 registros para os quais não consta informação de ocupação nos autos dos processos. Considera-se, dessa maneira, que o representante legal esperava durante a denúncia a informação de uma atividade além da de estudante para o denunciado, enquanto que em outros processos somente a informação estudante bastava como ocupação. O termo desempregado também consta no quadro, porque foi admitido que, quando o denunciado se declarou desempregado, este também exercia, em algum momento, atividade além de 
estudante. Com referência a 5 denunciados registrados somente como militantes, não foi possível identificar em que atividade profissional exatamente se enquadravam tais pessoas.

Nesse conjunto de resultados foi verificado que $88 \%$ dos estudantes não declararam desempenhar uma segunda atividade na ocasião em que foram processados, o que permite concluir que a condição estudantil supera a condição de trabalhador entre os estudantes militantes denunciados.

\subsubsection{Distribuição e permanência dos denunciados por processos judiciais}

Conforme mencionado, 54\% dos 707 processos (383) contêm pelo menos um estudante. Entre os 332 processos classificados por atividades diferentes da ação estudantil, a maioria dos processos (63\%) não tinha mais que $50 \%$ de estudantes envolvidos na ação subversiva de um determinado processo. Por outro lado, $37 \%$ dos processos continham a participação relevante de $51 \%$ a $100 \%$ de estudantes entre os denunciados por processo judicial. Esses valores comprovam que a ação estudantil ultrapassou o limite dos 51 processos classificados efetivamente como sendo do setor estudantil (Gráfico 7).

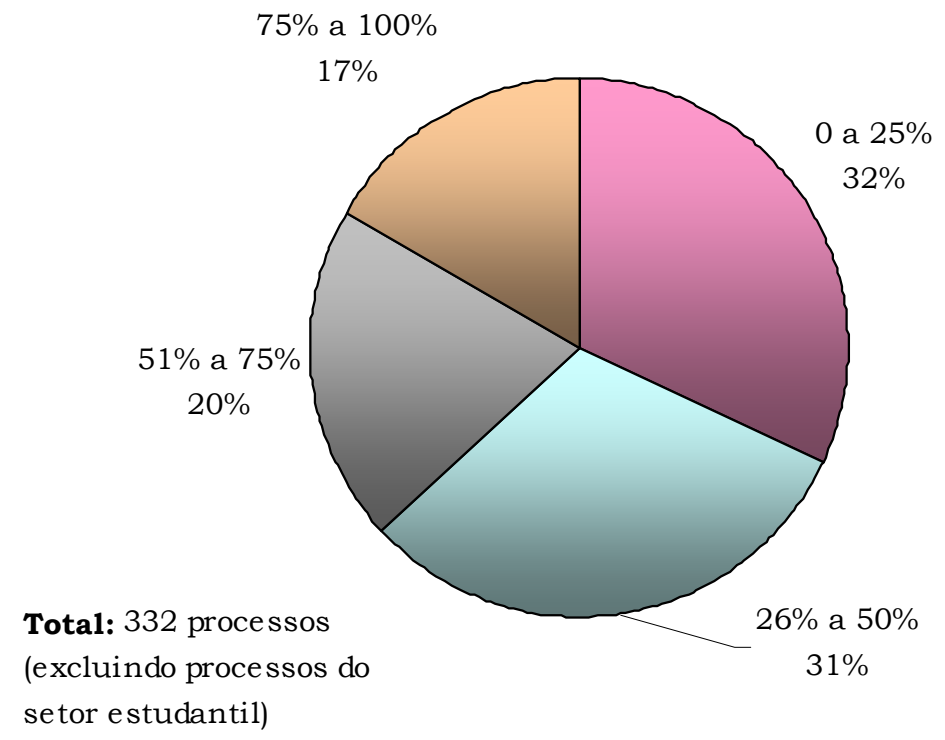

Gráfico 7: Estudantes por processos judiciais em todos os grupos (excluindo setor estudantil) 
Conforme mostra o Gráfico 8, em relação aos processos agrupados como do setor estudantil, $67 \%$ dos processos contaram com a presença de $75 \%$ a $100 \%$ de estudantes entre os denunciados por processo. Conforme esperado, nenhum processo pertencente ao setor estudantil continha menos que $25 \%$ de estudantes entre o rol de denunciados por processo. Dessa maneira, confirmase que nestes 51 processos a ação de militância era norteada pelos estudantes.

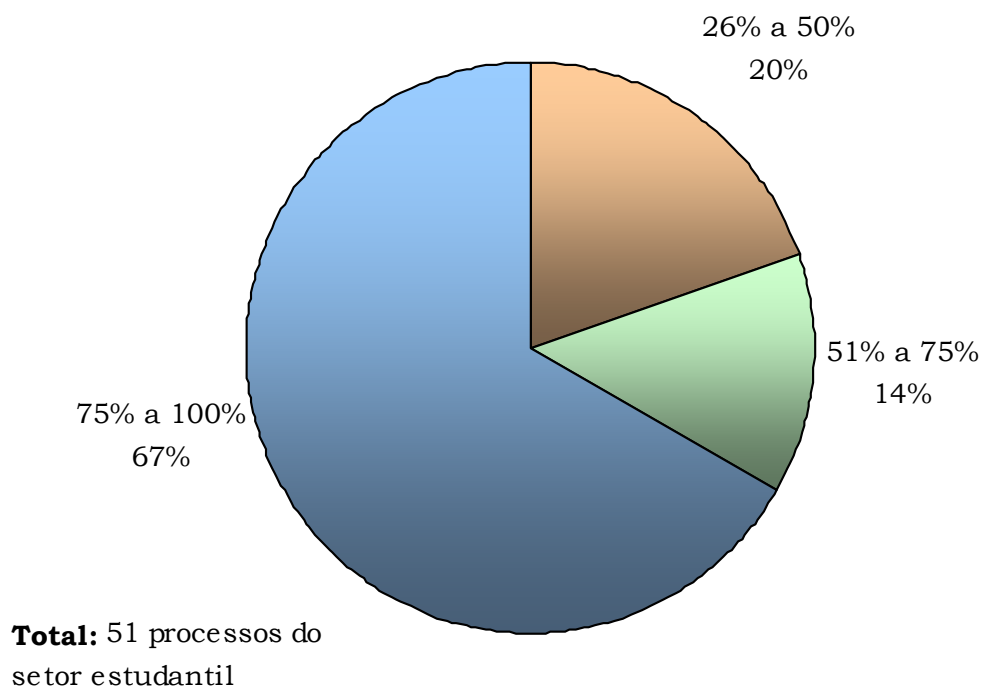

Gráfico 8: Estudantes por processo judicial no setor estudantil

O Gráfico 9 mostra que 42 estudantes foram denunciados, tanto em processos do setor estudantil, quanto em outros setores, enquanto que 182 estudantes foram processados somente por atividades classificadas como do setor estudantil. A interseção de estudantes, em diferentes grupos, pode ser o indício de que o estudante reincidiu na prática subversiva e acabou por "migrar" para atividades de grupos da esquerda envolvidos na luta armada. 


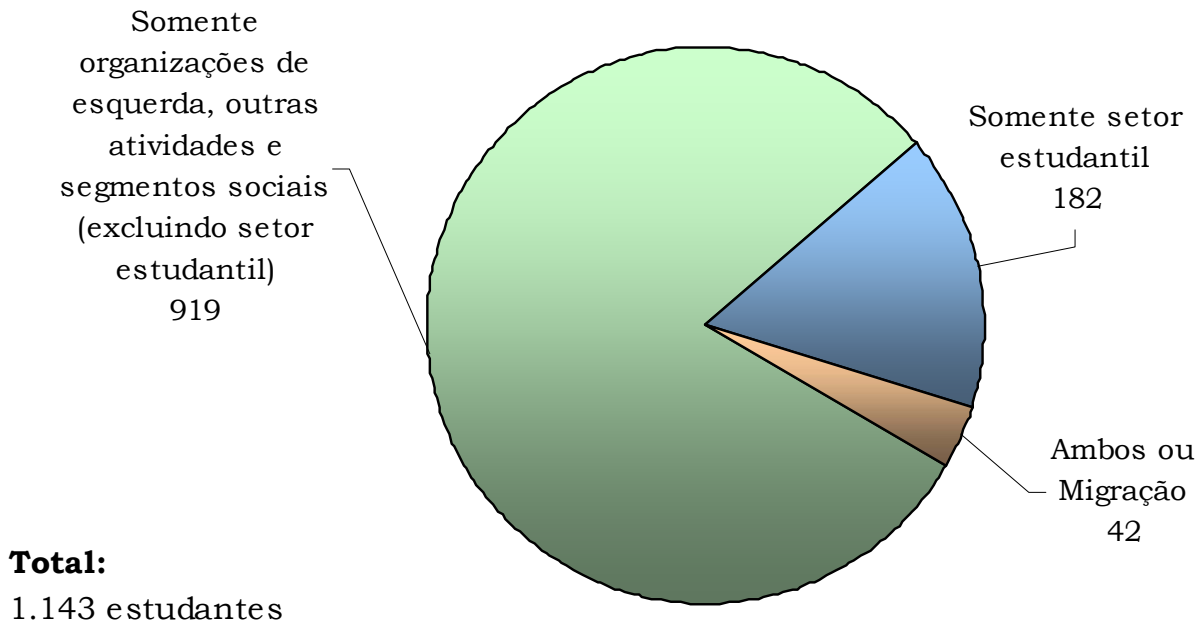

Gráfico 9: Participação estudantil distribuída por grupos de atuação nomeados pelo Projeto BNM

Confirmando essa proposição, observa-se, no Gráfico 10, que dos 42 estudantes processados, somente $8(19 \%)$ foram denunciados simultaneamente, tanto em processos do setor estudantil, quanto em outros setores, enquanto 32 (76\%) estudantes foram, primeiramente, denunciados por atividades relacionadas ao setor estudantil e, em momento seguinte, denunciados em processos dos outros setores. Somente 1 estudante (2\%) foi denunciado inicialmente por atividades classificadas em outros setores, para depois ser arrolado em processos do setor estudantil. Outro estudante foi processado pelas atividades do setor estudantil, depois em outros setores, em seguida novamente em atividade estudantil e ao final, novamente em organizações de esquerda. 


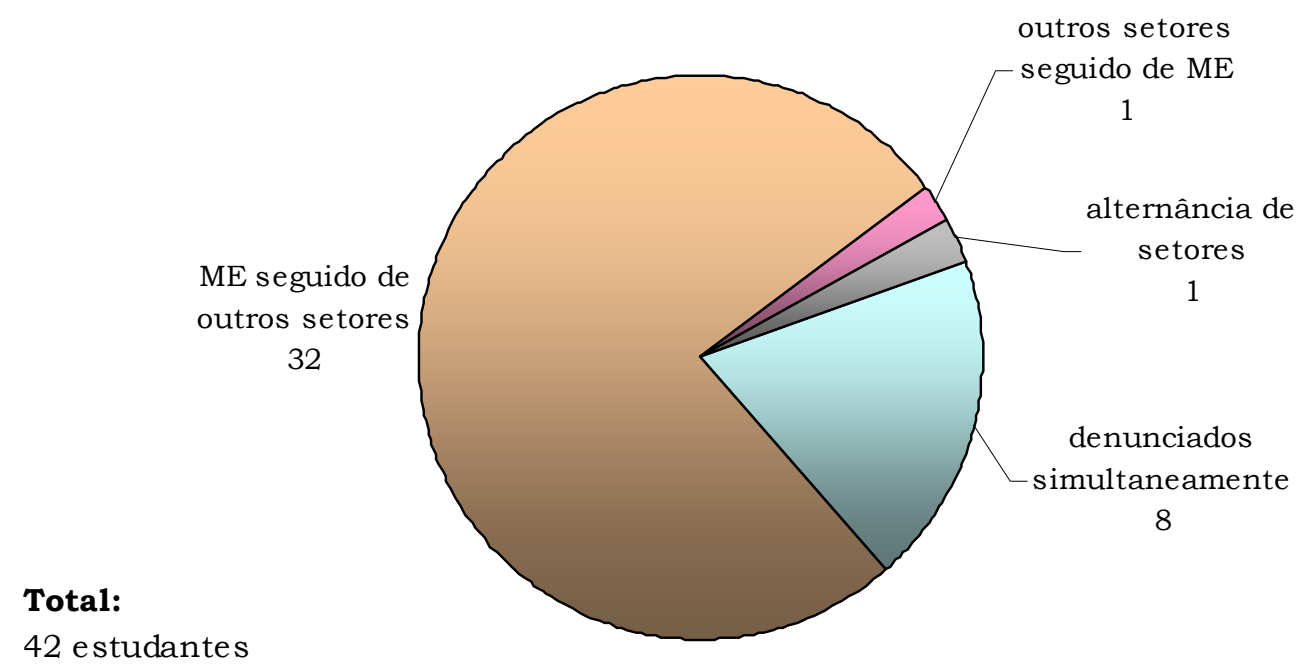

Gráfico 10: Desenvolvimento da atuação dos denunciados segundo classificação do BNM

É conveniente reafirmar que a classificação dos processos judiciais nas três categorias - segmento social, organizações de esquerda e outras atividades foi um recurso metodológico adotado pelo Projeto: Brasil Nunca Mais. Com evidentes dificuldades, os pesquisadores do Projeto BNM tiveram que nomear as atividades dos denunciados, conforme explicado pelos pesquisadores do Projeto:

Como costuma acontecer em todo trabalho de classificação, observou-se que muitos dos processos analisados na pesquisa BNM apresentavam-se caracteristicas intermediárias entre esses três grandes grupos estabelecidos [segmento social, organizações de esquerda e outras atividades]. Por exemplo: um processo formado para apurar atividades de um determinado partido clandestino freqüentemente abordava também "delitos" como "reorganização da UNE", "subversão sindical" etc.

Nesses casos, nosso método foi nortear a classificação por aquilo que, na denúncia dos processos, ou nos documentos centrais do inquérito, aparecia com maior ênfase ou representava um "delito" teoricamente mais "grave", para utilizar a terminologia empregada pelos próprios autores de 
toda essa documentação policial e judicial (MITRA ARQUIDIOCESANA, 1987, p.16).

Portanto, a idéia de que o estudante migrou de um tipo de atividade para outro pode ser reavaliada conforme o exame de cada processo. Por exemplo, o BNM 13, processo judicial classificado na categoria organizações de esquerda, referente às atividades da Ação Popular (AP), trata da prisão de um grupo de estudantes universitários reunidos, em São Paulo, em março de 1965. Os estudantes foram presos após o retorno de um congresso estudantil na cidade de Campinas. Com o grupo foi constatada a posse de material vinculado a AP, conseqüentemente, os pesquisadores do BNM classificaram esse processo judicial como de organização de esquerda. É fato que os pesquisadores do Projeto BNM procuraram nortear classificação segundo a atividade denunciada, no entanto, pelo fato de todos os denunciados serem estudantes e estarem envolvidos em um congresso estudantil, todos poderiam ter sido classificados dentro do setor estudantil.

Esta análise da "migração" do estudante de um processo originalmente do setor estudantil para um processo de outro setor, contribui para avaliar a permanência do estudante na ação militante e no seu "amadurecimento" na ação revolucionária, dado que $95 \%$ do total dos denunciados concomitantemente no setor estudantil e em outras categorias foram, cronologicamente, processados inicialmente por atividades que o Projeto BNM classificou como prática da atividade estudantil e em seguida, denunciados em processos de outros setores.

\subsection{Caracterização dos estudantes nos onze processos judiciais}

Os onze processos judiciais selecionados para essa análise contêm 72 denunciados, contudo, esse valor corresponde a 69 estudantes, sendo que três foram denunciados duas vezes em processos diferentes. Para a análise dos dados referentes a idade, sexo e trabalho dos 72 denunciados é utilizado o mesmo método aplicado para o universo geral de 1.691 denunciados. 
A seleção destes processos demonstra um recorte dentro do universo estudantil evidenciado no item anterior. Primeiramente, o Quadro 7 apresenta a relação de estudantes em ordem alfabética e em qual processo judicial foram denunciados $^{36}$ (numeração $\mathrm{BNM}$ ). Em seguida, passa-se para a análise dos dados referentes à idade e sexo, no qual foi possivel verificar as informações para todos os estudantes. Também foram identificados alguns dados a respeito de outras atividades desenvolvidas pelos estudantes, cursos em que estavam matriculados e estado civil.

Quadro 7: Relação alfabética dos Denunciados nos respectivos BNMs

\begin{tabular}{|c|c|c|}
\hline & Denunciados & BNM \\
\hline 1 & Afonso & 163 \\
\hline 2 & Ageu & 429 \\
\hline 3 & Alanir & 408 \\
\hline 4 & Almicar & 429 \\
\hline 5 & Álvaro Lins & 354 \\
\hline 6 & Antonio Carlos & 163 \\
\hline 7 & Antonio M. & 690 \\
\hline 8 & Antonio N. & 354 \\
\hline 9 & Apolo & $623 / 429$ \\
\hline 10 & Carlos B. & 354 \\
\hline & Carlos R. & 429 \\
\hline 12 & Celerino. & 163 \\
\hline 13 & César & 401 \\
\hline & Cláudio & 354 \\
\hline & Doralina & 429 \\
\hline 16 & Edson & 163 \\
\hline 17 & Erasmo & 5 \\
\hline & Francisco & 5 \\
\hline & Geraldo & 354 \\
\hline & Gilce & 429 \\
\hline & Hamilton & 429 \\
\hline 22 & Helenira & 489 \\
\hline
\end{tabular}

\footnotetext{
36 Não foram relacionados os sobrenomes dos denunciados, optando-se em trabalhar com os prenomes, visto que essas informações estão disponiveis em ARQUIDIOCESE DE SÃO PAULO. Projeto Brasil Nunca Mais (Tomo III, Perfil dos Atingidos). São Paulo: Arquidiocese de São Paulo, 1985c.
} 
Quadro 7 (cont.): Relação alfabética dos Denunciados nos respectivos BNMs

\begin{tabular}{|c|c|c|}
\hline & Denunciados & BNM \\
\hline & Hélio & 535 \\
\hline 24 & Henrique & 429 \\
\hline & Honestino & $623 / 5$ \\
\hline & João & 429 \\
\hline & Jorge & 429 \\
\hline 28 & José A. & 5 \\
\hline 29 & Jose C. & 429 \\
\hline & Jose C. N & 429 \\
\hline & José Fabiano & 5 \\
\hline & José Leonardo & 5 \\
\hline 33 & Jose Luiz & 429 \\
\hline 34 & José Maria & 695 \\
\hline & Jose Pedro & 623 \\
\hline & Jose Renato & 623 \\
\hline 37 & Juarez & 163 \\
\hline 38 & Juracy a & 690 \\
\hline 39 & Jurandir & 695 \\
\hline 40 & Jurany & 429 \\
\hline 41 & Lenine & 5 \\
\hline 42 & Luiz Antonio & 163 \\
\hline 43 & Luiz C. & 5 \\
\hline 44 & Luiz G. & 429 \\
\hline 45 & Luiz G.T. & 429 \\
\hline 46 & Magda . & 429 \\
\hline 47 & Marco Antonio & 429 \\
\hline 48 & Marcos Antonio. & 354 \\
\hline 49 & Maria. & 535 \\
\hline 50 & Marilda & 401 \\
\hline 51 & Mauricio D. & 429 \\
\hline 52 & Mauricio M. & 163 \\
\hline 53 & Mauro & 5 \\
\hline 54 & Nauro. & 429 \\
\hline 55 & Omar & 163 \\
\hline 56 & Paulo C. & 354 \\
\hline 57 & Paulo & 623 \\
\hline
\end{tabular}


Quadro 7 (cont.): Relação alfabética dos Denunciados nos respectivos BNMs

\begin{tabular}{|c|c|c|}
\hline & Denunciados & BNM \\
\hline 58 & Paulo S. & 5 \\
\hline 59 & Pedro & 163 \\
\hline & Rafael & 489 \\
\hline 61 & Raimundo & 429 \\
\hline 62 & Reinaldo & 163 \\
\hline 63 & Samuel & 5 \\
\hline 64 & Stênio & 163 \\
\hline 65 & Tadeu & 354 \\
\hline 66 & Tibério & 429 \\
\hline 67 & Waldo & 429 \\
\hline 68 & Waltamir & $5 / 354$ \\
\hline & Walter & 623 \\
\hline
\end{tabular}

\subsubsection{Idade}

O Quadro 8 mostra que os valores porcentuais na faixa etária de 21 a 25 anos foram similares, tanto em relação ao geral de todos os estudantes contidos no Projeto BNM, quanto aos denunciados somente nos processos do setor estudantil e, por último, nos onze processos. Dessa maneira, pode-se entender que o recorte da fonte documental proposto para esta pesquisa segue a mesma distribuição observada para toda a população estudantil denunciada nos processos do Projeto BNM.

Quadro 8: Relação de Idade em todos universos documentais

\begin{tabular}{cccc}
\hline Idade & $\begin{array}{c}\text { BNM } \\
\text { Total }\end{array}$ & $\begin{array}{c}\text { Setor } \\
\text { estudantil }\end{array}$ & $\begin{array}{c}\text { Onze } \\
\text { processos }\end{array}$ \\
\hline$<21$ & $20 \%$ & $19 \%$ & $18 \%$ \\
\hline 21 a 25 & $64 \%$ & $70 \%$ & $65 \%$ \\
\hline$>25$ & $16 \%$ & $11 \%$ & $17 \%$ \\
\hline Total & $\mathbf{1 0 0} \%$ & $\mathbf{1 0 0} \%$ & $\mathbf{1 0 0} \%$ \\
\hline
\end{tabular}

Entre os 72 denunciados a maioria, ou seja, $82 \%$ dos estudantes tinham 21 anos ou mais, e mais uma vez foi registrada a ocorrência de 
estudantes com idade superior aos 25 anos (17\%). Este resultado confirma a conclusão de que a condição juvenil novamente não representou o fator predominante entre os estudantes denunciados.

\subsubsection{Sexo}

O resultado obtido nos onze processos indica certa similaridade entre os valores nos três níveis de análise deste trabalho, ou seja, a maioria dos denunciados (entre 80\% e 90\%) eram do sexo masculino. Outro aspecto relevante nestes dados, é que entre 6 estudantes do sexo feminino, 4 pertenciam a faixa etária entre 21 a 25 anos, conseqüentemente, a maioria da militância estudantil estava concentrada nesta faixa etária.

\subsubsection{Curso}

Com a leitura completa dos processos foi possivel identificar 22 cursos que os estudantes cursavam no momento do delito. O curso com maior número de estudantes denunciados foi o de Direito, com 4 estudantes, seguido do curso de Engenharia, com 3 estudantes. Logo em seguida, os cursos de Farmácia, Geologia e Medicina tinham 2 estudantes cada. Os cursos de Arquitetura, Filosofia, História, Jornalismo, Matemática, Secundário e Sociologia possuíam, por sua vez, somente um estudante cada. Desses valores, conclui-se que a ação militante, dentro da universidade, pode ter sido distribuída entre todas as faculdades, afinal, dentro do universo pesquisado nenhum dos cursos teve o índice próximo a $10 \%$ de estudantes denunciados. De qualquer maneira, a abertura de outros processos poderia complementar este tipo de informação, o que só é possivel através da leitura completa dos autos.

\subsubsection{Estudante trabalhador}

Entre os 72 denunciados, 15 declararam outra atividade além de estudantes. A atividade declarada com maior freqüência foi a de professor. Neste caso, foi verificado que 6 estudantes cursavam a faculdade e lecionavam em escolas de ensino de primeiro e segundo graus. Em seguida, a atividade mais praticada entre os denunciados, com 4 estudantes, era o funcionalismo público, que compreendia atividades desde escrevente judiciário a guarda 
municipal. Outras atividades como jornalista, médico, contabilista e comerciário, foram declaradas somente uma vez.

Sobre o fato de alguns estudantes desempenharem outra atividade, além da estudantil, pode ser mais um indício de que a condição de ser estudante trabalhador não foi o fator influenciador na militância estudantil, pois a maioria (79\%) não exercia uma segunda atividade. Por outro lado, este fato também contrapõe-se à premissa de que o universo estudantil foi composto somente por estudantes provenientes da classe média, considerando que $21 \%$ dos denunciados neste corpus documental estavam envolvidos com uma segunda atividade além de estudar. Dessa maneira, somente a leitura de outros processos poderá retratar quantos estudantes estavam envolvidos de maneira simultânea com o trabalho e o universo acadêmico.

\subsubsection{Estado civil}

Em relação ao estado civil dos estudantes denunciados, foi observado que $14 \%$ dos denunciados nos onze processos eram casados. Os casados representam $18 \%$ dos estudantes que faziam parte da faixa etária entre 18 e 31 anos. Os solteiros estão distribuídos por todas as faixas etárias enquanto que sobre 8 estudantes, entre as idades de 20 e 30 anos, não foi possivel determinar o estado civil. O número maior de solteiros pode estar relacionado à situação estudantil dos denunciados, aquém da estabilidade profissional.

Por outro lado, de acordo com Tadeu Antônio Dix Silva, entre os militantes da esquerda era comum o estabelecimento de "união entre os casais sem a necessidade de contrair casamento, como conseqüência das próprias idéias libertárias que possuí" (2007, p.302). Outro aspecto cogitado por Silva é que a luta armada influenciava no estilo de vida dos militantes que resultava quase sempre na clandestinidade. De acordo com esta mentalidade, a sobrevivente da guerrilha do Araguaia e, também, militante do movimento estudantil na Universidade Federal do Rio de Janeiro no ano de 1968, Criméia Alice Schmidt de Almeida relata:

O André não foi o meu primeiro companheiro. Tive um outro, quando vivia no Rio. Naquela época, qualquer sentimento saudade, amor, paixão - era visto, por todos nós, como uma 
peia, como algo que podia nos impedir de fazer a revolução. Sobre esse prisma, é que eu tratava as minhas relações afetivas. Dogmatismo, sectarismo de jovem. O meu primeiro companheiro, o Flavio, acabou também indo para o Araguaia e é um dos desaparecidos. Quando fiz a opção de militar no campo, terminei o relacionamento, pois, eu o via como um empecilho para essa nova modalidade de militância. Havia que romper, dado que o importante, o fundamental, era a revolução. No Araguaia, durante algum tempo, eu fui a única mulher jovem, pois, a companheira que já se encontrava lá, a Elza, tinha mais de cinqüenta anos. Os companheiros eram jovens, todos da minha idade. Obviamente, fui muito assediada. Mas agindo sempre dentro dessa perspectiva, de que um envolvimento emocional seria um empecilho para a militância, resisti, durante um bom tempo a esses assédios (LIMA, 1998, p.509).

O depoimento de Criméia Alice Schmidt de Almeida é referente ao cotidiano dos militantes das organizações clandestinas de esquerda. Entretanto, essa experiência é percebida, também, no caso de estudantes militantes, pois, dentro das organizações de esquerda, houve relevante participação da militância estudantil. 


\section{Fase Judicial}

Neste capítulo é iniciada a análise da segunda base documental desta pesquisa, composta pelos onze processos judiciais classificados pelos pesquisadores do Projeto BNM como do setor estudantil. O propósito, nesta parte do trabalho, é retratar a dinâmica judicial em que os processos judiciais selecionados estavam inseridos.

O capítulo apresenta uma breve explicação da estrutura e do funcionamento da Justiça Militar durante o período estudado. A seguir, são analisados os onze processos judiciais, primeiro quanto à tipificação dos crimes cometidos; posteriormente, em relação aos prazos da tramitação dos processos; e por último, quanto aos resultados dos julgamentos.

\subsection{Justiça Militar}

Desde 1938, a Justiça Militar era regulamentada pelo Decreto-lei no925 de 2 de dezembro de 1938, que estruturou os órgãos da Justiça Castrense em três categorias de conselhos: a) Conselho Especial de Justiça; b) Conselho Permanente de Justiça e; c) Conselho de Justiça ${ }^{37}$. A estrutura da Justiça Militar, bem como as leis que regulamentavam seu funcionamento, só seriam alteradas, em 1969, com os Decretos-leis 1001 (Código Penal Militar), 1002 (Código de Processo Penal Militar) e 1003 (Lei de Organização Judiciária Militar). Com a instauração destas leis de funcionamento, a Justiça Militar

37 Das Autoridades Judiciárias e seus Auxiliares. A função de cada Conselho:

a) Conselho Especial de Justiça, nas auditorias, para processo e julgamento de oficiais, excetuados os generais;

b) Conselho Permanente de Justiça, nas auditorias, para processo e julgamento de acusados que não sejam oficiais;

c) Conselho de Justiça, nos corpos, formações e estabelecimentos do Exército, para processo de desertores e de insubmissos.

Art. $6^{\circ}$ Cada auditoria compor-se-á de um auditor, um promotor, um advogado, um escrivão, dois escreventes, um oficial de justiça e um servente.

Parágrafo único. Em cada auditoria haverá um suplente de auditor e um adjunto de promotor, exceto na auditoria de correição, onde não haverá promotor, advogado nem oficial de justiça.

Art. $7^{\circ}$ Alem das autoridades de que tratam os artigos anteriores, haverá um procurador geral junto ao Supremo Tribunal Militar (Decreto-lei 925/38, CAPÍTULO II). 
passou a ser estruturada em 12 Circunscrições Judiciárias Militares (CJMs) ${ }^{38}$, com seus limites definidos em função da base das Forças Armadas na região Região Militar, Distrito Naval e Comando Aéreo Regional. Nas CJMs funcionavam as Auditorias Militares, que constituíam a primeira instância da Justiça Militar. Nas CJMs do Rio de Janeiro estavam instaladas sete Auditorias. Em São Paulo e no Rio Grande do Sul, havia três auditorias cada. Todas as outras CJMs possuíam somente uma Auditoria.

As Auditorias eram formadas por um Conselho Permanente de Justiça (CPJ), composto por quatro juízes militares e um juiz auditor civil, sendo presidido pelo militar que tivesse a patente mais alta. Além dos juizes, cada auditoria tinha um promotor e um advogado de oficio ${ }^{39}$.

As Auditorias funcionavam como primeira instância da Justiça Militar desde o Código de Organização Judiciária e Processo Militar de 1920 (SILVA, 2007b). No período do Estado Novo, como mencionado na Introdução, o foro militar recebeu recursos dos processos originados no Tribunal de Segurança Nacional (TSN), que julgava os acusados de infração à Lei de Segurança Nacional. O Supremo Tribunal Militar passou a integrar o Poder Judiciário a partir da Constituição de 1934.

\subsection{Legislação}

Quando se deu a instauração do regime militar, a Lei de Segurança Nacional vigente era a Lei 1.802 de 5 de janeiro de 1953, utilizada para processar os crimes contra a nação. Esta lei definia os "crimes contra o Estado e a Ordem Politica e Social" (Lei 1.802/53). Desde a extinção do Tribunal Nacional, em 1945, como citado, os crimes contra a segurança externa eram de competência da Justiça Militar.

De acordo com os pesquisadores do Projeto BNM, a lei 1.802/53 tinha como principal objetivo cuidar da defesa da Ordem Politica e Social estabelecida na Constituição Federal, através de punição a quem "tentasse mudar, por meios

\footnotetext{
38 O Decreto-lei n- 1003/1969 estabelece e regulamenta a Lei da Organização Judiciária Militar.

39 Decreto-lei n- 1003/69, CAPÍTULO IV. Da Organização dos Conselhos de Justiça, artigos 13 ao 24.
} 
violentos, a forma de governo por ela estabelecida" (Arquidiocese de São Paulo, 1985e, p.3). A lei apresentava 48 artigos com a descrição de todos os delitos considerados crime contra o Estado.

Em destaque e reforçando a afirmação dos pesquisadores do Projeto BNM, os artigos $2^{\circ}, 3^{\circ}$ e $4^{\circ}$ demonstram a preocupação com a Ordem social:

Art. 2- Tentar:

I - submeter o território da Nação, ou parte dele, à soberania de Estado estrangeiro;

II - desmembrar, por meio de movimento armado ou tumultos planejados, o território nacional desde que para impedi-lo seja necessário proceder a operações de guerra;

III - mudar a ordem politica ou social estabelecida na Constituição, mediante ajuda ou subsídio de Estado estrangeiro ou de organização estrangeira ou de caráter internacional;

$I V$ - subverter, por meios violentos, a ordem politica e social, com o fim de estabelecer ditadura de classe social, de grupo ou de indivíduo;

Art. 3- Promover insurreição armada contra os poderes do Estado.

Art. 4- Praticar:

I - atos destinados a provocar a guerra civil se esta sobrevém em virtude deles;

II - devastação, saque, incêndio, depredação, desordem de modo a causar danos materiais ou a suscitar terror, com o fim de atentar contra a segurança do Estado (Lei 1.802/53).

Como competência da Justiça Militar, a Lei 1.802 previa o processo e julgamento dos crimes previstos em determinados artigos. ${ }^{40}$ Por outro lado,

40 LEI Nº1.802/53:

Art. 42. Competem à Justiça Militar, na forma da legislação processual respectiva, o processo e julgamento dos crimes previstos nos arts. $2^{\circ}$, incisos I a III, $6^{\circ}$, quando a vitima for autoridade militar e, finalmente, 24, 25, 26, 27, 28 e 29.

Art. 24. Constituírem ou manterem os partidos, associações em geral, ou, mesmo, o particular, milícias ou organizações de tipo militar de qualquer natureza ou forma armadas ou não, com ou sem fardamento, caracterizadas pela finalidade combativa e pela subordinação hierárquica. 
parte dos crimes era julgada na Justiça ordinária e previa o recurso para o Supremo Tribunal Federal ${ }^{41}$. Todavia, como mencionado, com a instauração, em 1965, do Ato Institucional №2, o artigo 8- deste Ato transferiu para a esfera da Justiça Militar o julgamento de todos os crimes previstos na Lei $1.802 / 53$

Essa transferência de competência entre os Poderes foi conseqüência de alguns conflitos entre o Executivo e o Judiciário. Esses impasses entre os dois Poderes iniciaram-se por ocasião da implantação da mencionada "Operação Limpeza", quando o governo instaurou um grande número de Inquéritos Policiais Militares (IPMs) para investigar atividades "subversivas" de funcionários civis e militares, pertencentes aos níveis municipal, estadual e federal. Após a conclusão do Inquérito, a decisão final pela punição cabia ao presidente, aos governadores de Estado ou aos prefeitos (ALVES, 1984, p.56). No entanto, a maioria dos indiciados recorreu ao Judiciário, conseqüentemente, o Supremo Tribunal Federal (STF) e os tribunais estaduais, na maioria das vezes, revogaram as punições. Essa interseção de poderes fez com que centenas de IPMs fossem interrompidos por decisão do Judiciário, antes mesmo de alcançar a fase judicial (ARQUIDIOCESE DE SÃO PAULO, 1985, p.170).

Pena:- reclusão de 1 a 3 anos aos cabeças, e da metade para os demais agentes, além da perda, em favor da União do material usado.

Art. 25. Promover ou manter, no território nacional, serviço secreto destinado à espionagem. Pena:- reclusão de 8 a 20 anos, agravada de um terço na reincidência.

Art. 26. Fornecer, mesmo sem remuneração, à autoridade estrangeira, civil ou militar, ou a estrangeiros, informações ou documentos de caráter estratégico e militar ou de qualquer modo relacionados com a defesa nacional.

Pena: - reclusão de 2 a 4 anos.

Art. 27. Utilizar-se de qualquer meio de comunicação, para dar indicações que possam pôr em perigo a defesa nacional.

Pena:- reclusão de 2 a 6 anos, se o fato não constituir crime mais grave.

Art. 28. Possuir ou ter sob a sua guarda ou à sua disposição, importar, comprar ou vender, ceder ou emprestar ou permutar, por conta própria ou de outrem, câmara aerofotográfica, sem licença da autoridade competente.

Pena:- reclusão de 6 meses a 2 anos.

Art. 29. Conseguir, transmitir ou revelar, para o fim de espionagem politica ou militar, documento, notícia ou informação que em defesa da segurança do Estado, ou no seu interêsse politico, interno ou internacional, deva permanecer secreto.

Pena:- reclusão de 6 a 15 anos.

41 Parágrafo único: O processo e julgamento dos demais crimes definidos nesta lei [excluindo os arts $2^{\circ}$, incisos I a III, $6^{\circ}$, quando a vitima for autoridade militar e, finalmente, 24, 25, 26, 27, 28 e 29] competem à Justiça ordinária, com recurso para o Supremo Tribunal Federal (Constituição, art. 101, II, c) e serão regulados pelo disposto no Código de Processo Penal. 
A repressão atingiu todos os níveis de hierarquia do Estado e vários governadores foram afastados de seus cargos, através da suspensão de direitos políticos e da cassação de mandatos. Em reação, a maioria dos governadores afastados, por exemplo, Mauro Borges (Goiás), Plínio Coelho (Amazonas) e Miguel Arraes (Pernambuco) recorreram ao STF e obtiveram a concessão de Habeas-Corpus e a preservação do foro especial em virtude do cargo elevado. Após a concessão de uma série de Habeas-Corpus, Osvaldo Trigueiro do Vale reconheceu que essas decisões do Supremo criaram um impasse dos mais sérios na harmonia e independência dos três poderes da República (1976, p.4). De acordo com Maria Helena Moreira Alves (1984, p.57), estabeleceu-se um confronto entre a estrutura legal tradicional e a estrutura paralela legal - a "revolucionária". Essa "brecha" jurídica fez com que vários indiciados recorressem ao STF, já que a lei determinava que os crimes contra o Estado e contra a ordem politica e social deveriam ser julgados na Justiça Comum, enquanto que a Justiça Militar seria responsável por julgar crimes de militares ou crimes militares praticados por civis. De maneira geral, neste primeiro momento do regime militar, foi uma prática comum o STF acatar os pedidos de Habeas-Corpus. Em relação à tensão entre os Poderes, Osvaldo Trigueiro do Vale reconhece que:

Esse comportamento do Supremo assanhava ainda mais os
setores militares inconformados com a proteção jurídica aos
que retiveram o comando executivo de alguns estados. Alias
nunca cessaram as manifestações anti-Supremo, sobretudo
por serem suas decisões consideradas fruto dos liames
partidários anteriores (1976, p.57).

A decretação do AI-2 pelo Executivo, além de resolver o conflito de poderes, também interferiu na estrutura do funcionamento do Superior Tribunal Militar (STM) e do Supremo Tribunal Federal (STF). O Ato aumentou o número de ministros do STM de onze para quinze juízes vitalícios ${ }^{42}$, enquanto

\footnotetext{
42 Estabelece o Código da Justiça Militar. Da SECÇÃO I. Do Supremo Tribunal Militar: Art. $8^{\circ}$ : Da. Do Supremo Tribunal Militar: Art. $8^{\circ}$ : O Supremo Tribunal Militar compor-se-á de onze juízes vitalícios com a denominação de Ministros, nomeados pelo Presidente da República, dos quais quatro escolhidos entre os generais efetivos do Exército, três dentre os generais efetivos da Armada e quatro civis.
} 
que o STF passou de 11 para 16 ministros $^{43}$. Essas mudanças garantiram um maior apoio dos Tribunais para o Executivo, já que a nova formatação dos Supremos contava com maioria dos ministros indicados pelo governo militar.

As mudanças operadas pela nova legislação fortaleceram a ação judicial militar, apesar da “incapacidade para a função judicante” dos juízes militares, segundo os pesquisadores do BNM. As críticas destacaram a incapacidade dos juízes na apreciação de provas; falta de neutralidade dos juízes em relação ao caso a ser julgado, pois muitos inquéritos foram elaborados em unidades militares onde as investigações eram conhecidas por todos e inclusive pelo Juiz Militar; atraso nos prazos para o oferecimento de denúncia e a valorização dos inquéritos policiais em detrimento das provas produzidas na fase judicial (Arquidiocese de São Paulo, 1985e, p.24). De acordo com Vilma Antunes Maciel, que se baseou nas afirmações dos pesquisadores do BNM:

“... o que era muito criticado do ponto de vista doutrinário, era o fato de a composição dos Conselhos ser formada por quatro juizes militares e apenas um juiz togado, o que dificultava as decisões das questões jurídicas” (2006, P.39)

Apesar disso, a análise deste trabalho evidenciou que, em relação aos onze processos do setor estudantil, não se verifica este tipo de conduta por parte dos juízes auditores. Na verdade, em alguns dos processos judiciais foi possivel identificar a preocupação, por parte dos juízes, em aceitar as denúncias que atendessem os requisitos da lei.

Parágrafo único: As vagas de ministros togados serão preenchidas da forma seguinte: metade do número de vagas, por brasileiros natos de notória competência jurídica e reputação ilibada, com prática forense de mais de dez anos, não devendo ter menos de trinta e cinco, nem mais de cinqüenta e oito anos de idade, da livre escolha do Presidente da República; e, as restantes, por auditores e Procurador-Geral da Justiça Militar, desde que tenham mais de trinta e cinco anos de idade e seis, pelo menos, de exercício em seus cargos (Decreto-lei №925/38).

O Ato Institucional №2 alterou: Art. $7^{\circ}$ - O Superior Tribunal Militar compor-se-á de quinze Juízes vitalícios com a denominação de Ministros, nomeados pelo Presidente da República, dos quais quatro escolhidos dentre os Generais efetivos do Exército, três dentre os Oficiais Generais efetivos da Armada, três dentre os Oficiais Generais efetivos da Aeronáutica e cinco civis.

Parágrafo único - As vagas de Ministros togados serão preenchidas por brasileiros natos, maiores de 35 anos de idade, da forma seguinte:

I - três por cidadãos de notório saber jurídico e reputação ilibada, com prática forense de mais de dez anos, da livre escolha do Presidente da República;

43 "Art. 98 - O Supremo Tribunal Federal, com sede na Capital da República e jurisdição em todo o território nacional, compor-se-á de dezesseis Ministros”.

"Parágrafo único - O Tribunal funcionará em Plenário e dividido em três Turmas de cinco Ministros cada uma." (BRASIL, ATO INSTITUCIONAL no2, 1965). 
Por exemplo, no BNM 623, a denúncia foi aceita pelo juiz auditor depois de recusar a primeira e a segunda sofrer um recurso. $O$ juiz auditor considerou a denúncia inepta ${ }^{44}$ porque não teve destacada a participação de cada denunciado e também, segundo o juiz auditor, por não ter se baseado nos termos do relatório do IPM. A segunda sofreu um recurso porque o juiz auditor não aceitou a denúncia contra o estudante Honestino, referido na primeira. Honestino foi retirado do rol de denunciados, sob o fundamento de estarem prescritos os crimes que lhe foram atribuídos e tendo-se em vista sua menoridade (BNM 623, fl. 681).

No caso BNM 429, que tratou da atuação de estudantes em uma passeata estudantil e distribuição de material subversivo, o Procurador denunciou o estudante Apolo com embasamento legal fundamentado nos Artigos $33^{\circ}, 36^{\circ}$ e $38^{\circ}$, itens II e III do Decreto-lei 314/67. Porém, o Juiz Auditor, demonstrando preocupação com o rigor técnico da denúncia, rejeitou o artigo $38^{\circ}$ e seus itens. De acordo com o juiz, a imputação no item II não menciona o que há de subversivo ou criminal no jornal; apenas faz referência ao seu nome ("Piquete") e quanto à imputação ao inciso III do mesmo Artigo, não exprime o aliciamento que teria feito, especialmente quanto ao Lugar e Tempo (BNM 429, fl.1888).

Outros denunciados também não foram enquadrados no Artigo $38^{\circ}$, porque o juiz auditor argumentou o seguinte:

\begin{abstract}
Rejeito a imputação oferecida contra esses mesmos relativamente ao art.38 $8^{\circ}$, porque os fatos correspondentes não estão claramente circunstanciados. A denúncia está muito genérica e excessivamente concisa, não ensejando o conhecimento do FATO concreto, em todas as suas caracteristicas, para que a defesa possa exercer-se em toda sua plenitude. É pacífica a jurisprudência do Egrégio STM e do Colendo STF, que denúncia, em tais circunstâncias, não deve ser aceita (BNM 429, fl.1888).
\end{abstract}

\footnotetext{
44 Denúncia inepta: que não produz efeitos jurídicos por não atender às exigências legais (diz-se de petição inicial, denúncia ou queixa).
} 
O Juiz Auditor não aceitou a denúncia para outros cinco estudantes, porque os fatos a eles imputados não estavam devidamente circunstanciados na denúncia (BNM 429, fl.1888). Finalizando a decisão, o Juiz justifica com outros motivos a decisão de também rejeitar a denúncia para outros dois estudantes. Para o primeiro estudante, considerou que José J. já tinha sido condenado pelo artigo $36^{\circ}$ quanto ao mesmo fato. A ação imputada foi praticada à mesma época. Dessa maneira, seria um "Bis In Idem"5" (p.1888). No segundo caso, o Juiz considerou que o fato de ter o estudante Nassin hospedado integrantes da Ação Popular em sua casa "não [corresponderia] ao tipo delitivo deserto no aludido artigo 36" (BNM 429, fl.1888). Esses dois casos demonstram que, em certa medida, a repressão judicial estava fundamentada na lei.

Em relação às leis de Segurança Nacional que constam nos onze processos judiciais, observa-se que o período estudado abrange principalmente a vigência das Leis 1802/53 e do Decreto-lei 314 de 1967. Por outro lado, com exceção do BNM 690, todos os outros dez processos, quando atingiram a esfera do STM nos anos de 1970, passaram a ter invocado os decretos-lei 510 e 898, ambos com vigência a partir do ano de 1969. Dessa maneira, a leitura dos autos é permeada por diferentes decretos conforme a vigência da legislação.

Após demonstrar como estava estruturada a Justiça Militar e a legislação no período correspondente aos processos analisados, no item seguinte são abordadas as etapas do processo judicial.

\subsection{Percurso dos processos judiciais}

Como esclarecido, os julgamentos dos processos judiciais respeitavam as normas regidas pelo respectivo Código da Justiça Militar ${ }^{46}$ vigente no período dos processos. Anterior à instauração do processo judicial, há a instauração do

45 Bis in idem: Duas vezes sobre o mesmo; repetição. Neste caso poderia ser reconhecida a litispendência, que segundo os artigos 148 a 155 do Código de Processo Penal Militar, o réu poderia ser julgado apenas uma vez por determinado crime.

46 a instauração das Leis de funcionamento e regulamentação da Justiça Militar em 1969 (DL/1001,1002 e 1003), a Justiça Militar foi regida pelo Código da Justiça Militar (Decreto-lei no925/38). 
Inquérito ${ }^{47}$, que é a etapa policial - de onde o Procurador Militar (Promotor) tira os argumentos para a formação da denúncia. O Inquérito Policial Militar (IPM) tinha o objetivo de apurar o crime e sua autoria. A fase seguinte, efetivamente, é a instauração do processo judicial, que começa quando o juiz recebe a denúncia e, a partir disto, ocorre sua tramitação na Justiça.

$\mathrm{Na}$ fase judicial, ocorria primeiramente a instrução probatória, composta por todos os atos praticados durante o processo até o início das alegações finais. Nessa fase eram produzidas todas as provas, como os interrogatórios, depoimentos (testemunhas e declarantes) e apresentação de provas técnicas ou periciais.

As alegações finais ocorriam após o encerramento da instrução probatória, quando o Ministério Público e a defesa apresentavam as alegações que justificavam o pedido de absolvição ou condenação do denunciado. Primeiro, o presidente dava a palavra ao promotor, em seguida, ao defensor, para sustentarem suas alegações orais. O prazo, tanto para a acusação como para a defesa, era de três horas. O promotor e o defensor poderiam replicar e treplicar em prazo inferior a uma hora. Tanto o promotor como os defensores não poderiam usar palavras ofensivas e deveriam apreciar o estrito valor jurídico das provas (Decreto-Lei 925/38: art. 227, $\S 1^{\circ}$ ao $\S 4^{\circ}$ ).

Os artigos 228 e 229 do Código da Justiça Militar estabeleciam que, ao final dos debates, o conselho passaria a deliberar em sessão secreta e qualquer juiz poderia examinar os autos e pedir ao auditor esclarecimentos sobre questões de direito que se relacionavam com o julgamento. Ao fim da sessão secreta, os juizes eram convidados a se pronunciar sobre a causa, apresentando em seguida seus votos. O primeiro a votar era o auditor, ao qual se seguiam outros juízes, a começar do mais novo e por último, o presidente. Declarada a decisão, o auditor expedia o mandado de prisão contra o réu, se este fosse condenado, ou alvará de soltura se fosse absolvido. No caso de o réu estar presente à sessão e ser condenado, a voz de prisão the seria dada pelo presidente do conselho. As sentenças e as decisões do conselho eram

\footnotetext{
47 Inquérito Policial (IP) - se feito na alçada da Polícia Civil e Inquérito Policial Militar - se feito na alçada das Forças Armadas (AQUINO, 2004, p.53).
} 
fundamentadas e redigidas pelo auditor e, por fim, assinadas por todos os juízes. Quando datilografadas, também eram rubricadas pelo auditor (DecretoLei 925/38: art. 229 e 230).

A fase judicial de um processo terminava em geral com a sentença, mas poderia haver recurso, como explica Maria Aparecida de Aquino:

A partir dai, os Conselhos de Justiças Militares - compostos de quatro juízes militares e um juiz togado-, da Auditoria e da Circunscrição Judiciária Militar (CJM) correspondente, pronunciava a sentença absolutória ou condenatória do acusado. Em ambas as circunstâncias cabia percurso da parte do Ministério Público ou dos advogados de defesa, ou seja, apelação para outra instancia, no caso, o Superior Tribunal Militar, em Brasília.

Com base nas provas arroladas nos autos, na sentença pronunciada e nas razões (da defesa/Ministério Público) e contra-razoes (de defesa/Ministério Público) da apelação, o Superior Tribunal Militar pronunciava a sentença de segunda instância, confirmando ou negando a anterior.

Poderia ainda haver uma terceira e última etapa, ou seja, a apelação da sentença do Superior Tribunal Militar para o Supremo Tribunal Federal (STF). A sentença pronunciada nesta instância era definitiva e irrecorrivel (AQUINO, 1994, p.237).

Todos os onze processos analisados nesta pesquisa tiveram recursos e atingiram a esfera do STM, mas não avançaram para a esfera do STF. Portanto, é possivel acompanhar todo o percurso do processo desde a abertura do IPM até a sentença final. 


\subsection{Análise dos Processos}

Inicia-se, neste item, o estudo de caso dos onze processos. Pretende-se, através da identificação dos motivos incriminatórios presentes nas denúncias 48 de cada um dos onze processos, evidenciar como a atividade subversiva estudantil foi criminalizada com o respaldo da lei. Conforme o Quadro 9, podese agrupar cinco tipos de ações incriminatórias nestes processos judiciais ${ }^{49}$. Esse agrupamento considerou os artigos incriminatórios invocados na denúncia, como exemplificado. A denúncia passava pelo crivo do juiz auditor, quando poderia ser aceita ou modificada, segundo a percepção que o juiz tivesse da atividade subversiva.

Quadro 9: Setor Estudantil: onze processos: Motivos incriminatórios

\begin{tabular}{|l|c|c|c|c|c|c|c|c|c|c|c|}
\hline $\begin{array}{l}\text { Motivos } \\
\text { Incriminatórios \BNM }\end{array}$ & 5 & 163 & 354 & 401 & 408 & 429 & 489 & 535 & 623 & 690 & 695 \\
\hline $\begin{array}{l}\text { Distribuição de material } \\
\text { subversivo }\end{array}$ & & $\square$ & & $\square$ & & & & & & & $\square$ \\
\hline Depredação de imóveis & & & & & & $\square$ & $\square$ & & & $\square$ & \\
\hline $\begin{array}{l}\text { Comício-relâmpago e } \\
\text { passeata estudantil }\end{array}$ & & & $\square$ & & $\square$ & & & $\square$ & $\square$ & & \\
\hline $\begin{array}{l}\text { Posse de material } \\
\text { explosivo }\end{array}$ & & & & & & & & $\square$ & & & \\
\hline Seqüestro & $\square$ & & & & & & & & & & \\
\hline
\end{tabular}

Alguns processos judiciais incidiram em mais de um motivo, contudo, a classificação foi norteada pela prioridade e a relevância da ação. O Quadro 10 mostra a incidência das atividades subversivas, nos onze processos, segundo a classificação desta pesquisa.

\footnotetext{
48 Denúncia é a peça processual onde os Procuradores formulam sua acusação perante o juiz auditor competente a fim de que se inicie a ação penal contra a pessoa a quem se imputa a autoridade de um crime ou de uma contravenção. A denúncia deve conter: a) a narração do fato criminoso com suas circunstâncias; b) a qualificação do delinqüente, ou seus sinais característicos se for desconhecido; c) as razões de convicção ou presunção da delinqüência (Decreto-Lei 925/38: art. 188).

49 Neste item 2.2 foi utilizada parte do método de análise aplicado por Maria Aparecida de Aquino (1994, p. 249 até 282).
} 
Quadro 10: Onze processos do Setor Estudantil:

Motivos dos processos

\begin{tabular}{llc}
\hline $\begin{array}{c}\text { Motivos de abertura de Processos } \\
\text { Contra estudantes }\end{array}$ & Freqüência & \% \\
\hline Distribuição de material subversivo & 3 & $27 \%$ \\
Depredação de bens e imóveis & 3 & $27 \%$ \\
Passeatas e comícios-relâmpagos & 3 & $27 \%$ \\
Posse de explosivos & 1 & $9 \%$ \\
Seqüestro e cárcere privado & 1 & $9 \%$ \\
\hline
\end{tabular}

A seguir, será discutido cada um dos motivos mais comuns utilizados nas denúncias que fundamentam os onze processos judiciais contra os estudantes.

\subsubsection{Distribuição de material subversivo}

No motivo Distribuição de material subversivo, foram agrupados os processos (BNMs) 163, 695 e 401, que tiveram seus integrantes envolvidos principalmente com a divulgação de jornais e panfletos considerados subversivos.

Os três processos tiveram especialmente o embasamento legal fundamentado no Artigo 38- do Decreto-lei de 1967. O BNM 401 e o 695 tiveram especificamente invocado o Inciso II deste Artigo. Todos os itens do Artigo 38:- determinam crime quando:

Constitui, também, propaganda subversiva, quando importe em ameaça ou atentado à segurança nacional:

I - a publicação ou divulgação de notícias ou declaração;

II - a distribuição de jornal, boletim ou panfleto; [grifo meu]

III - o aliciamento de pessoas nos locais de trabalho ou de ensino;

IV - comício, reunião pública, desfile ou passeata;

$V$ - a greve proibida;

VI - a injúria, calúnia ou difamação, quando o ofendido for órgão ou entidade que exerça autoridade pública, ou funcionário em razão de suas atribuições; 
VII - a manifestação de solidariedade a qualquer dos atos previstos nos itens anteriores;

Das atividades militantes estudantis investigadas nos processos, observa-se que a maioria tinha o artigo da lei correspondente para qualificar determinada ação enquanto atividade subversiva. A seguir, alguns pontos dos três processos (BNMs) relacionados no primeiro motivo de incriminação.

\section{PROCESSO (BNM) 163}

Nestes processos foram investigadas as atividades subversivas da União Paranaense dos Estudantes (UPE), em referência à publicação e distribuição do jornal Afirmação. O inquérito policial, de 27 de outubro de 1967, elaborado pela Polícia Federal de Curitiba, atendeu ao pedido da EOEG da Aeronáutica do Estado do Paraná. Os estudantes foram denunciados pela Procuradoria nos Artigos 33- e 38- do Decreto-lei 314/67.

O Artigo $38_{-}^{\circ}$ já foi referido e o $33_{-}^{\circ}$ incrimina a quem:

Incitar publicamente:

I - à guerra ou à subversão da ordem político-social;

II - à desobediência coletiva às leis;

III - à animosidade entre as Forças Armadas ou entre estas

e as classes sociais ou as instituições civis;

IV - à.luta pela violência entre as classes sociais;

$V$ - à paralisação de serviços públicos ou atividades essenciais;

VI - ao ódio ou a discriminação racial:

Parágrafo único. Se o crime for praticado por meio de imprensa, panfletos, ou escritos e de qualquer natureza, radiodifusão ou televisão, a pena, será aumentada de metade.

\section{PROCESSO (BNM) 695}

Processo instaurado contra Jurandir e José Maria. Os dois réus foram responsabilizados pela distribuição do jornal estudantil "Liberdade" no dia 4 de 
outubro de 1967 na área da Usiminas, em Ipatinga (MG). Jurandir foi preso quando estaria distribuindo o jornal e José Maria foi apontado como responsável pela edição do periódico. O inquérito foi conduzido inicialmente pelo Contingente Policial Militar de Ipatinga, depois passou para a competência da Polícia Federal de Belo Horizonte. Foi invocado o Artigo 38․, Inciso II, do Decreto-lei 314/67 (referido).

\section{PROCESSO (BNM) 401}

Processo contra César de 23 anos e Marilda de 18 anos, presos em flagrante no dia 23 de julho de 1968, distribuindo panfletos pelas ruas de Belo

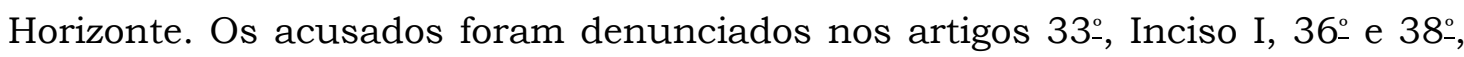
Inciso II do Decreto-lei 314 /67.

Além do Artigo 38ㅇ, que criminalizava a distribuição de material considerado subversivo, foi, também, invocado o Artigo 36․, que incriminava quem estivesse reorganizando clandestinamente partido cujo registro foi suspenso. Neste processo, foi compreendido que os estudantes estavam organizados com a intenção de fazer a UNE funcionar novamente, a despeito da sua situação de ilegalidade. Dessa maneira, observa-se a aplicação do artigo 36do Decreto-lei 314/67 que incrimina a quem:

Fundar ou manter, sem permissão legal, organizações de tipo militar, seja qual for o motivo ou pretexto, assim como tentar reorganizar partido politico cujo registro tenha sido cassado ou fazer funcionar partido sem o respectivo registro ou, ainda associação dissolvida legalmente, ou cujo funcionamento tenha sido suspenso.

\subsubsection{Depredação de bens e imóveis}

No motivo Depredação de bens e imóveis enquadram-se os processos (BNM) 489, 429 e 690. Este agrupamento contém os processos referentes às ações de pichações e depredações contra prédios e muros, que frequentemente aconteciam durante alguma manifestação de rua ou em um comício-relâmpago. 


\section{PROCESSO (BNM) 489}

No dia 25 de junho de 1967, por volta da meia-noite, no bairro da Consolação, na cidade de São Paulo, os denunciados picharam a face lateral divisória da Universidade Mackenzie, com inscrições consideradas injuriosas pela perícia (folhas 12/18): "Abaixo a Ditadura" - "29 Congresso UNE", "Greve até Solução"- "Abaixo a Direção". Foi invocado o Artigo 25- Decreto-lei 314/67, que determina crime quando o indivíduo:

Praticar devastação, saque, assalto, roubo, seqüestro,
incêndio ou depredação; ato de sabotagem ou terrorismo,
inclusive contra estabelecimento de crédito ou
financiamento, massacre, atentado pessoal; impedir ou
dificultar o funcionamento de serviços essenciais,
administrados pelo Estado, ou mediante concessão ou
autorização.

\section{PROCESSO (BNM) 429}

Neste processo, são apuradas as atividades das principais lideranças do movimento estudantil de Minas Gerais no ano de 1968. Apuram-se a realização de várias passeatas após 28 de março - morte de Edson Luis - com depredação de veículos oficiais, pichamentos de paredes com slogans subversivos, panfletagem, comícios, propaganda de luta armada, etc., tudo entre 28 de março e 4 de abril. A maioria dos estudantes foi denunciada nos Artigos 33-, 36e 38: todos do Decreto-lei 314/67.

\section{PROCESSO 690 (BNM)}

Processo contra Juracy e Antonio, que durante passeata no Ceará, contra o assassinato do estudante Edson Luiz, teriam conduzido uma bandeira do Vietnã e liderado a depredação do prédio do Serviço de Informações e Relações Culturais dos Estados Unidos - seguida de tentativa de incêndio. Os acusados foram denunciados na prática dos crimes previstos no Artigo 25- e no inciso IV do artigo 38․ do Decreto-lei 314/67.

\subsubsection{Comício-relâmpago e passeata estudantil}

No grupo de processos enquadrados no motivo Passeata e comíciorelâmpago foram agrupados os (BNMs) 623, 354 e 408. 


\section{BNM 623 (BNM)}

Os réus são seis estudantes acusados de liderarem várias manifestações estudantis em Brasília, no mês de setembro de 1966. Tais manifestações faziam parte da setembrada. ${ }^{50}$ Os estudantes foram acusados da depredação da Casa Thomas Jefferson, pertencente à Embaixada NorteAmericana. Esse processo, inicialmente, foi aberto na $4^{\mathrm{a}}$ R.M. e posteriormente passou para a $11^{\mathrm{a}} \mathrm{RM}$. Foram invocados os Artigos 9- e $17_{-}^{\circ}$ da Lei 1.802 de 1953, sendo que o enquadramento no Artigo 9- refere-se à acusação de funcionamento ilegal da UNE. Como observado no processo (BNM) 489, este delito passou a ser previsto pelo Artigo 36- no Decreto-lei 314/67. Contudo, anterior ao decreto de 1967, a Lei 1.802 de 1953 já previa como crime este tipo de ação através do artigo 9-, para aqueles acusados de:

Reorganizar ou tentar reorganizar, de fato ou de direito, pondo logo em funcionamento efetivo, ainda que sob falso nome ou forma simulada, partido político ou associação dissolvida por força de disposição legal ou fazê-lo funcionar nas mesmas condições quando legalmente suspenso.

O Artigo $17_{-}^{\circ}$ (Lei 1.802/53) está relacionado à ação de manifestação e desobediência em local público:

Instigar, publicamente, desobediência coletiva ao cumprimento da lei de ordem pública.

\section{BNM 354 (BNM)}

Os réus deste processo são 9 estudantes de Brasília acusados por dois delitos distintos. O primeiro, foi a soltura de imensos balões de tarja negra, durante o desfile de 7 de setembro de 1968, em protesto contra o governo militar. O segundo delito foi a invasão, no dia 12 de outubro de 1968, de uma quermesse organizada por algumas esposas de militares. Nesta quermesse, os estudantes distribuíram panfletos e tomaram o microfone à força para

\footnotetext{
50 Como informado na introdução deste trabalho, a setembrada corresponde às atividades do mês de setembro de 1966, quando os estudantes manifestaram-se em passeatas pelas principais cidades do país. Essas passeatas resultaram no "Dia Nacional de Luta contra a Ditadura".
} 
denunciar a prisão de seus colegas presos no XXX Congresso da UNE, em Ibiúna.

Os estudantes foram presos em flagrante por oficiais em trajes civis que compareceram à quermesse. Um dos réus estava pichando nos muros a frase "Viva a UNE". Os estudantes foram denunciados no artigo 38.- do Decreto-lei 314/67. O processo iniciou-se na $4^{\mathrm{a}}$ Auditoria Militar, porém nos anos de 1970, foi transferido para a recém inaugurada $11^{\text {a }}$ Auditoria Militar.

\section{BNM 408 (BNM)}

O único réu deste processo, Alanir, foi preso em flagrante, no dia 7 de setembro de 1968, em Goiânia, quando participava de manifestação de protesto durante o desfile em comemoração ao Dia da Pátria. O acusado estava gritando frases contra o governo e exigindo a libertação da estudante Olga ${ }^{51}$. O estudante foi indiciado no artigo 33․, Inciso II, por incitar os populares contra os policiais que efetuavam sua prisão; também indiciado no artigo $36_{-}^{\circ}$, por confessar ser presidente da União Brasileira dos Estudantes Secundários (UBES), entidade dissolvida pela lei e finalmente foi indiciado no Artigo 38․, Inciso IV, por ter efetuado comício relâmpago de caráter subversivo. Todos os artigos fazem parte do Decreto Lei 314 de 13 de março de 1967.

\subsubsection{Posse de explosivos}

No motivo Posse de explosivos, enquadra-se somente o processo BNM 535. Este BNM também poderia configurar no grupo de atividade Comíciorelâmpago e passeata estudantil, já que os estudantes foram também denunciados criminalmente segundo o artigo $38^{\circ}$, entretanto, optou-se por esta classificação pela singularidade da atividade.

\section{BNM 535}

Processo contra os estudantes universitários Maria Nadja e Hélio, de 22 e 21 anos, respectivamente, acusados de participarem de manifestações de rua

\footnotetext{
51 No acervo BNM Olga consta somente no BNM 186, no qual os réus são acusados de integrarem a VAR no Rio de Janeiro, participando de reuniões, guardando material militar, recebendo e discutindo documentos politicos, falsificando identidades, mantendo contatos de rua, fazendo levantamentos etc. (Arquidiocese de São Paulo. Arquidiocese de São Paulo, 1985 b, p.147)
} 
realizadas em Fortaleza, no Ceará, no dia 15 de outubro de 1968. Os estudantes foram acusados de participarem de comícios-relâmpagos para protestar contra a prisão dos participantes do Congresso de Ibiúna (SP). Os dois estudantes foram presos quando carregavam dois coquetéis Molotov numa sacola. O inquérito foi formado na Polícia Federal de Fortaleza, a partir da data das prisões. Os estudantes foram conduzidos para aquela repartição pelo delegado Luiz Colho de Carvalho, da Delegacia de Ordem Política e Social do Ceará, apontado como torturador de presos políticos em outros processos do Projeto BNM.

A denúncia foi baseada nos artigos $38_{-}^{\circ}$, nos IV, VII (referido) e $41_{-}^{\circ}$, do Decreto-lei 314/67:

Artigo 41: Importar, fabricar, ter em depósito ou sob sua guarda, comprar, vender, doar ou ceder, transportar ou trazer consigo armas de fogo ou engenhos privativos das Forças Armadas; ou quaisquer instrumentos de destruição, sabendo o agente que são destinados à prática de crime contra a segurança nacional.

\subsubsection{Seqüestro}

O processo (BNM) 5 é o único selecionado pelo motivo seqüestro $\boldsymbol{e}$ cárcere privado.

\section{BNM 5}

Processo contra 12 estudantes que seqüestraram e mantiveram um policial em cárcere privado, para interrogatórios, durante 18 horas dentro do campus da Universidade de Brasilia. Somente depois de negociações com a Polícia e com apoio da Reitoria, o policial foi libertado em troca da soltura de alguns estudantes que a Polícia havia prendido na ação que se seguiu, ao tomar conhecimento do seqüestro do policial. Os denunciados foram incursos no já citado artigo 25- do Decreto-lei 314/67.

Conforme constatado, a legislação de Segurança Nacional, em vigor durante o período analisado, previa invocar a Lei $1.802 / 53$ ou o Decreto-lei $314 / 67$, dependendo do ano em que tivesse ocorrido o delito. De acordo com os 
pesquisadores do Projeto BNM, os principais artigos invocados da Lei 1.802 para todos os processos correspondentes aos anos de 1964 a 1968 foram (1985e, p.19):

$2^{\circ}$ - Tentar mudar ou subverter a ordem politica e social

$9^{\circ}$ - Reorganizar ou tentar reorganizar partido ou associação dissolvida por força da lei

$10^{\circ}$ - Filiar-se ou ajudar com serviços ou donativos, ostensiva ou clandestinamente, mas sempre de maneira inequivoca, a qualquer das entidades reconstituidas ou em funcionamento na forma do artigo anterior.

$11^{\circ}$ - Fazer publicamente propaganda:

a) de processos violentos para a subversão da ordem politica ou social;

b) de ódio de raça, de religião ou de classe;

c) de guerra.

$\S 2^{\circ}$ Não constitui propaganda:

a) a defesa judicial;

b) a exaltação dos fatos guerreiros da história pátria ou do sentimento civico de defesa armada do País, ainda que em tempo de paz;

c) a exposição à crítica ou o debate de quaisquer doutrinas.

$\S 3^{\circ}$ Pune-se igualmente, nos termos deste artigo, a distribuição ostensiva ou clandestina, mas sempre inequivocamente dolosa, de boletins ou panfletos, por meio dos quais se faça a propaganda condenada nas letras $a, b$ e c do principio deste artigo.

Dos processos estudantis analisados nesta pesquisa, somente o BNM 623 invocou a Lei $1802 / 53$, em virtude da data do delito ter sido em setembro de 1966, enquanto que os outros dez processos tiveram a ocorrência da infração entre os anos de 1967 e 1968 e, dessa maneira, tiveram invocado o Decreto-lei 314/67. Como observado, de acordo com Projeto BNM o Artigo $9^{\circ}$ foi 
um dos artigos mais utilizados da Lei 1802. Confirmando esta análise, foi identificado este mesmo artigo no BNM 623.

Em relação ao Decreto-lei 314/67, o Projeto BNM destaca deste decreto os artigos mais invocados para todos os processos do acervo BNM durante o primeiro período do regime militar (1985e, p.20):

21: Tentar subverter a ordem ou estrutura politico-social vigente no Brasil, com o fim de estabelecer ditadura de classe, de partido politico, de grupo ou de individuo.

23: Praticar atos destinados a provocar guerra revolucionária ou subversiva 33: Incitar publicamente à guerra ou à subversão... [citado] 36 : Fundar ou manter, sem permissão legal... [citado]

O Quadro 11 mostra a freqüência dos artigos invocados do Decreto-lei 314 nos onze processos.

Quadro 11: Setor Estudantil: onze processos. Caracterização legal

\begin{tabular}{cccc}
\hline \multicolumn{4}{c}{ Decreto-lei 314/67 } \\
Artigo & Freqüência & $\%$ \\
\hline Artigo & 38 & 7 & $39 \%$ \\
Artigo & 33 & 4 & $22 \%$ \\
Artigo & 25 & 3 & $17 \%$ \\
Artigo & 36 & 3 & $17 \%$ \\
Artigo 41 & 1 & $6 \%$ \\
\hline \multicolumn{2}{c}{ Total } & $\mathbf{1 8}$ & $\mathbf{1 0 0 \%}$ \\
\hline
\end{tabular}

Conforme observado no Quadro 12, o artigo mais utilizado nos onze processos para criminalizar as atividades estudantis foi o Artigo $38^{\circ}$, invocado nos processos BNM 163, 354, 401, 429, 535, 690 e 695, que tratava da divulgação da propaganda subversiva. $\mathrm{O}$ artigo $33^{\circ}$ tinha redação próxima à do artigo $38^{\circ}$. Dessa maneira, todos BNMs que tiveram invocados o artigo $33^{\circ}$, BNM 163, 408 e 429, tiveram combinado o artigo $38^{\circ}$. 
Quadro 12: Setor Estudantil: onze processos.

Artigos incriminatórios mais invocados

\begin{tabular}{|c|c|c|c|c|c|c|c|c|c|c|c|}
\hline Artigos $\backslash$ BNM & $\mathbf{5}$ & $\mathbf{1 6 3}$ & $\mathbf{3 5 4}$ & $\mathbf{4 0 1}$ & $\mathbf{4 0 8}$ & $\mathbf{4 2 9}$ & $\mathbf{4 8 9}$ & $\mathbf{5 3 5}$ & $\mathbf{6 2 3}$ & $\mathbf{6 9 0}$ & $\mathbf{6 9 5}$ \\
\hline Artigo 25 & $\square$ & & & & & & $\square$ & & & $\square$ & \\
\hline Artigo 33 & & $\square$ & & $\square$ & $\square$ & $\square$ & & & & & \\
\hline Artigo 36 & & & & $\square$ & $\square$ & $\square$ & & & & & \\
\hline Artigo 38 & & $\square$ & $\square$ & $\square$ & $\square$ & $\square$ & & $\square$ & & $\square$ & $\square$ \\
\hline Artigo 41 & & & & & & & & $\square$ & & & \\
\hline
\end{tabular}

Entretanto, observa-se que os processos (BNM) 354 e 695 poderiam ter tido o artigo 33- relacionado entre os artigos incriminatórios, por tratarem, também, da divulgação de propaganda subversiva através panfletos ou escritos (Decreto-lei 314/67, § único).

Contudo, nem sempre a escolha do enquadramento do artigo incriminatório é concordante entre procuradoria e juiz auditor. Após análise do BNM 408 foi verificado que o juiz auditor não aceitou a denúncia com os artigos $33^{\circ}$ e $38^{\circ}$, por entender que o estudante deveria ser denunciado somente pelo artigo $36^{\circ}$, já que confessara sua "liderança e participação em funcionamento da Associação dissolvida legalmente, no caso a União Brasileira dos Estudantes Secundaristas” (BNM 408, Folha 43). A Procuradoria Militar da $4^{a}$ R.M. recorreu ao STM e, como resultado, conseguiu que somente o Artigo 38 fosse acolhido pelo Auditor Militar. Os Ministros reconheceram que o juiz auditor deveria reconsiderar o enquadramento no artigo $38^{\circ}$ :

Confessada pelo indiciado a sua participação em passeata proibida, de caráter subversivo, não se justifica que o juiz deixe de receber a denúncia quanto ao delito do artigo 38, IV do Decreto-lei 314 de 13-3-1967. Dá-se provimento ao recurso da Procuradoria Militar da $4^{a}$ R.M. para, em parte reformar a decisão recorrida (BNM 408, Folha 43).

A denúncia, com embasamento legal no Artigo $36^{\circ}$, demonstra que, mesmo na ilegalidade, os estudantes continuaram com as atividades da UNE. Todos os denunciados, nesta atividade, também, estavam envolvidos com a divulgação de idéias consideradas subversivas e o incitamento público para a 
prática da subversão, pois foram enquadrados simultaneamente nos Artigos $33^{\circ}$ e 38 do Decreto-lei 314/67.

Outro exemplo do ajuste da aplicação dos artigos incriminatórios, por parte do juiz auditor, foi encontrado no BNM 401. Neste BNM, os estudantes foram denunciados pelos Artigos $33^{\circ}$ e $38^{\circ}$. Contudo, o juiz auditor também não aceitou o enquadramento no inciso I do Artigo $33^{\circ}$, porque entendeu que o estudante não incitou publicamente "à guerra ou à subversão da ordem políticosocial" ao distribuir panfletos com conteúdo subversivo (DECRETO-LEI $314 / 67)$.

\subsection{Prazos dos processos}

A estrutura judiciária militar, com três níveis de instância, traduziu-se em um longo caminho para os estudantes percorrerem até a busca da absolvição definitiva. Esse caminho deveria ser seguido pelos condenados que tinham recursos para apelar no Superior Tribunal Militar e, quando necessário, no Supremo Tribunal Federal. Este meio também era utilizado por aqueles que lutavam pela manutenção da sentença absolutória contra reformas propostas pela Procuradoria. O período entre a sentença na Auditoria (primeira instância) e o resultado da Apelação no STM, para os onze processos analisados, variou de dois meses até seis anos.

A maioria dos processos (8) teve julgada a Apelação no periodo de até um ano. Por outro lado, 3 processos demoraram de 3 a 6 anos para terem julgada a Apelação no STM. Em algumas situações, a explicação para a morosidade da Justiça pode estar ligada à atitude de réu na condição de revel, devido à legislação não permitir a apelação do réu à revelia52.

\footnotetext{
52 Da apelação: Artigo $301^{\circ}$ : A apelação será interposta por simples petição, dentro do prazo improrrogável de quarenta e oito horas, seguintes à intimação da sentença ou à sua leitura em sessão do conselho, na presença das partes ou de seu advogado ou curador. $\S 1^{\circ}$ Tratando-se de réu solto ou de réu revel, a apelação de sentença condenatória só poderá ser interposta se o réu se recolher à prisão. Da Revelia. Artigo 202 ${ }^{\circ}$ : O presidente do conselho, logo que o réu seja considerado revel nos termos do art. 199, lhe nomeará um curador que se incumbirá de sua defesa até o julgamento, podendo interpor os recursos legais, excetuada a apelação de sentença condenatória, a qual somente poderá ser interposta depois de recolhido o réu à prisão e de haver este sido devidamente intimado da mesma sentença (Decreto-lei No925/38). Artigo 527 : O réu não poderá apelar sem recolher-se à prisão (Decreto-lei No1002/69). (Grifo meu)
} 
No caso do BNM 401 foi constatado, através da análise dos autos, que o julgamento da apelação demorou 4 anos em virtude do estudante condenado ter permanecido foragido. Somente depois de cinco anos da sentença condenatória o réu apresentou as razões para apelação. Das razões do apelante compreende-se que o réu só entrou com o pedido de apelação porque, ao retornar ao Brasil para candidatar-se a uma vaga de emprego, era preciso ter todos seus compromissos com a Justiça em ordem. Dessa maneira, assim que chegou ao Brasil em 1973, entregou-se a polícia e entrou com a apelação contra a sua condenação de 1969. Já a apelação do processo BNM 408, demorou 6 anos para ser apreciada pelo STM, em virtude de que o estudante condenado a revelia em 1969 não apelou da sentença condenatória até o ano de 1975. O recurso ao STM só ocorreu em decorrência da prisão do réu em outubro de 1974. Conseqüentemente, completou-se o prazo de prescrição da pena ${ }^{53}$ e a defesa apelou da condenação com argumentos de que:

"Somente depois de decorridos os quatro anos extintivos da punibilidade pela prescrição é que em 4 de outubro de 1974 veio a ser preso o apelante, de modo que sua prisão não interrompeu o prazo da prescrição como ocorreria se a prisão houvesse ocorrido antes de decorridos os quatro anos a contar da data da sentença condenatória."(BNM 408, página 194)

Do julgamento do pedido de Apelação, em 1975, o STM decidiu:

"Acordam em Tribunal, por unanimidade de votos, preliminarmente julgar extinta a punibilidade de Alanir pela prescrição da ação penal (...)" (Resultado da Apelação).

\footnotetext{
53 O réu havia sido condenando à pena de um ano e três meses pelo artigo 36o e a um ano pelo artigo 38o item II, ambos do Decreto-lei no314/67. Os Artigos $36^{\circ}$ e $38^{\circ}$ fixam penas máximas de 2 anos cada. Em virtude da condição de foragido não foi considerada a pena de 2 anos e 3 meses e sim as penas máximas de cada artigo em que o réu foi condenado:

Artigo 125o do CPM (DL1001/69): A prescrição da ação penal, salvo o disposto no $\S 1^{\circ}$ deste artigo, regula-se pelo máximo da pena privativa de liberdade cominada ao crime, verificando-se: $\mathrm{V}$ - em oito anos, se o máximo da pena é superior a dois e não excede a quatro;

VI - em quatro anos, se o máximo da pena é igual a um ano ou, sendo superior, não excede a dois;
} 
A análise destes dados demonstra que há especificidades, em cada processo, que precisam ser consideradas para avaliar os motivos de prazos tão destoantes.

Em relação aos prazos para a formação de culpa, ou seja, o período compreendido entre a data da denúncia e a data da sentença, não poderia exceder o período de trinta dias. Esse prazo é o tempo máximo que o cidadão pode permanecer preso enquanto aguarda seu julgamento (Decreto-lei no-925/38, artigo 222).

Em alguns casos, o réu pode aguardar em liberdade, no entanto, o constrangimento e transtorno são perenes na vida de qualquer cidadão que aguarda a conclusão de um processo em liberdade ou preso. Em relação aos onze processos, como observado no Quadro 13, nenhum dos processos atendeu às exigências legais de 30 dias entre a denúncia e o julgamento.

Quadro 13: Setor Estudantil: onze processos. Prazos para os julgamentos

\begin{tabular}{cc}
\hline Denúncia - Julgamento & Auditoria \\
\hline Até 1 ano & 4 \\
1 a 2 anos & 3 \\
2 a 3 anos & 3 \\
4 anos & 1 \\
\hline Total & $\mathbf{1 1}$ \\
\hline
\end{tabular}

Segundo o Projeto BNM, praticamente a totalidade $(99,6 \%)$ dos processos judiciais do período de 1964 a 1968 demorou mais que o dobro do prazo previsto na lei para a formação de culpa dos denunciados (1985e, p.23). Dessa maneira, os prazos praticados para os onze processos confluem com os do universo documental do Projeto BNM para o mesmo período.

\subsection{Decisões}

Dos 72 réus julgados pelo Conselho Permanente de Justiça nos onze processos, 46 denunciados (64\%) foram absolvidos na primeira instância da Justiça Militar. O Ministério Público apelou contra todas as sentenças 
absolutórias e, em 19 delas, ficou evidente que o MP buscou, de fato, a condenação do estudante na segunda instância. Entretanto, conseguiu reverter a sentença somente em um caso. Contudo, no caso de 27 absolvições, o MP concordou e recomendou a manutenção da sentença absolutória, mas por força do Artigo 73 do Decreto-lei no898/69, o Procurador apelou ao STM em função da obrigatoriedade de recorrer de toda absolvição. Segundo Mattos, através deste recurso, o STM controlava as sentenças absolutórias decretadas pelas Auditorias (MATTOS, 2002, p.60).

Em relação aos 23 estudantes condenados, o Ministério Público pediu a manutenção da sentença contra dois réus. Entre 21 condenados, somente seis apelaram ao STM, sendo que três tiveram a manutenção da condenação, dois tiveram a punibilidade extinta por prescrição da pena e somente um estudante foi absolvido após recorrer ao STM.

Os procuradores apelaram de fato em $41 \%$ dos casos de absolvição, demonstrando certa insatisfação em relação às decisões dos juízes auditores. Por outro lado, os resultados das sentenças de apelação demonstraram que os Ministros do STM, em grande medida, concordaram com as sentenças das Auditorias. Afinal, dos 46 réus absolvidos na primeira instância, somente um estudante, relacionado no BNM 5, teve sua sentença reformada e foi condenado no STM. Em relação aos 23 condenados, somente um estudante, relacionado no BNM 163, teve a sentença reformada para absolvição.

É importante ressaltar que, dos 72 réus denunciados nos processos, 3 não chegaram a ser sentenciados. Como mencionado, o estudante Honestino, relacionado no BNM 623, teve sua participação suspensa dos autos e, no BNM 429 , dois estudantes foram banidos do território nacional durante o julgamento do processo.

Apesar dos indícios de tortura ${ }^{54}$ de quatro estudantes dentre os sessenta e nove relacionados nos onze processos judiciais analisados nesta dissertação, não serão abordados fatos relativos a este assunto nesta pesquisa. Primeiro,

$54 \mathrm{O}$ acervo do Projeto BNM contém um volume com todas as informações referente à tortura sofrida por todos as pessoas arroladas nos processos judiciais. (ARQUIDIOCESE DE SÃO PAULO, 1985e). 
porque nos processos analisados não houve menção a estes fatos, entende-se que a denúncia pode ter acontecido por ocasião de outros processos. Segundo, porque este trabalho restringe-se à análise exclusiva dos processos judiciais, de forma a revelar como se deu a repressão nos tribunais. 


\section{Julgamentos}

Neste capítulo, são abordadas as ações dos procuradores e advogados, com a intenção de demonstrar o olhar da Acusação a respeito do estudante, bem como a voz do advogado, através das justificativas e argumentações da defesa. Encerrando esse capítulo, algumas observações a respeito das sentenças indicam quais argumentações convenceram a tomada de decisões dos representantes dos Conselhos de Justiça.

\subsection{Acusação}

Com o encerramento da investigação e apuração do crime contra a segurança nacional, o delegado elaborava um relatório que despachava junto com o inquérito policial militar (IPM) para as Auditorias Militares. O juiz auditor recebia o IPM e remetia, ao procurador militar, para que fizesse a denúncia. $O$ ponto de partida do processo judicial [era] a denúncia legalmente válida e aceita pelo juiz auditor (ARQUIDIOCESE DE SÃO PAULO, 1986, p. 178).

O procurador militar era o representante do Ministério Público na acusação e tinha interesse de punir e condenar os infratores da lei pelos crimes previstos na Lei de Segurança Nacional. Contudo, no final da instrução probatória, caso julgasse a acusação improcedente, o procurador poderia recomendar a absolvição do acusado. Não obstante a essa decisão, como mencionado, o Ministério Público era obrigado a recorrer ao STM de toda sentença absolutória ${ }^{55}$.

Após o aceite da denúncia pelo juiz auditor, o procurador continuava em suas funções de acusação. Primeiramente, convocava as testemunhas além das que haviam sido ouvidas no inquérito, e as substitua, até o máximo de três,

\footnotetext{
55 Da legislação anterior a 1969: Artigo $103^{\circ}$ : Ao promotor incumbe: g) recorrer obrigatoriamente para o Supremo Tribunal Militar das decisões de não recebimento da denúncia e das sentenças de absolvição, quando fundadas em dirimentes ou justificativas, ou quando se tratar de crimes funcionais ou de homicídio; (Decreto-lei 925/38: Capítulo V. Das atribuições do Ministério Públicas e Auxiliares da Justiça Militar). A partir de 1969: Artigo 73º: Ao Ministério Público cabe recorrer obrigatoriamente, para o Superior Tribunal Militar: a) do despacho do Auditor que rejeitar, no todo ou em parte, a denúncia; b) da sentença absolutória (Decreto-lei 898/69).
} 
quando o interesse da justiça o exigisse; acusava os criminosos e promovia o pedido de prisão e execução das sentenças e, como mencionado, invariavelmente recorreria das sentenças absolutórias ${ }^{56}$.

Quando os processos judiciais subiam para a esfera do STM, era necessário conter um arrazoado elaborado pelo procurador militar, que atuava na primeira instância, com a sua posição a respeito da sentença do Conselho de Justiça. No STM os autos eram encaminhados para o Procurador-Geral da Justiça Militar, que também deveria expor sua opinião em um parecer a respeito da sentença. Conseqüentemente, estes pareceres, tanto na primeira instância, quanto na segunda, evidenciam como o Ministério Público retratou o estudante militante nestes dois momentos da fase judicial.

Ao oferecer as denúncias nos onze processos judiciais, os procuradores militares descreveram as atividades subversivas dos estudantes como resultantes da capacidade de liderança de alguns indivíduos e do envolvimento destes com as atividades irregulares da UNE. Dessa maneira, as argumentações mais comuns para qualificar a conduta delituosa dos estudantes denunciados eram, em primeiro, destacar a sua capacidade de incitar grupos de estudantes para ações subversivas e, em segundo, ligar o denunciado ao funcionamento ilícito da UNE ou de qualquer entidade estudantil que estivesse atuando na irregularidade desde a instauração da Lei Suplicy de 1964.

Os procuradores destacaram, insistentemente, o comando e a capacidade de incitamento dos denunciados. Das palavras da acusação, destacam-se alguns exemplos:

O estudante foi mentor da conclamação feita aos estudantes no dia 28/3/68, pela televisão, transcrita da fita gravada nos autos, cujo conteúdo incita o povo à subversão da ordem politica social (BNM 429, fl. s/ $n$ ).

[o denunciado] aliciando os estudantes para as manifestações estudantis de rua, onde explicitou detalhadas instruções sobre o comportamento da massa estudantil face às possiveis ações policiais, inclusive

56 Todas as atribuições do Procurador (Promotor): Artigo 103 do Decreto-lei 925/38. 
detalhando o procedimento das reações contra a integridade física dos elementos da Polícia; embora não confesse, apenas, que o seja, os autos demonstram ser este denunciado, o principal mentor das violências praticadas durante as manifestações estudantis (BNM 623, fl.3).

Responsabilizar a UNE, como patrocinadora dos atos subversivos dos estudantes, era prática comum adotada pelos procuradores militares e pelos procuradores-gerais. Contudo, esta abordagem transcendia por todas as instâncias da repressão, sendo possivel encontrar, nos relatórios policiais, a sustentação para esta visão perniciosa da entidade estudantil que passava a ser divulgada pelos procuradores. Deste feito, observa-se, no relatório policial, a fundamentação para a elaboração da denúncia pelo Procurador do BNM 401:

A União Nacional dos Estudantes (UNE), órgão representativo dos universitários brasileiros, ao eclodir o Movimento Revolucionário de 31 de marco de 1964, estava transformada num dos principais focos geradores da agitação e subversão que assolavam a Pátria, motivo pelo qual foi extinta, tendo a Lei 4.464, de 9/11/1964, criado o Diretório Nacional dos Estudantes (DNE), com sede na Capital Federal.

As lideranças da classe, docemente acostumadas a indiscriminado gasto de polpudas verbas espúrias e à subversão sem repressão, inconformaram-se com a perda que julgavam irreparável e, ao arrepio da lei, tudo fizeram e fazem para manter o funcionamento $e$ prestigiar a mencionada UNE e, mais, quase sem deixando de lado os interesse estudantis especificos, levaram grande parte da classe universitária a engajar-se no terreno perigoso $e$ impatriótico da subversão esquerdista, almejando a derrubada do Poder Constituído e a cubanização do Brasil, através da luta armada, "se preciso".

Assim, a UNE, atuando na clandestinidade, continuou à agitação e à subversão no meio universitário, trazendo isto, grande desassossego para a população ordeira $e$ 
considerável prejuízo para o comércio - com suas periódicas paralisações - e para o Governo (BNM401, fl49).

Em outro processo judicial encontrou-se a mesma argumentação:

Todos os denunciados são dirigentes estudantis da União Nacional dos Estudantes (UNE) entidade fora da Lei, declaradamente esquerdista, objetivando sempre a subversão (BNM 623, fl.9).

Entretanto, a Procuradora-Geral Marly Valle Monteiro demonstrou uma visão pragmática em relação á ilegalidade da UNE e suprimiu qualquer discussão entre acusação e defesa a respeito da condição legal, ou não, da entidade, argumentando:

A discussão, em torno do assunto, parece-nos, no entanto, de pouca importância. Legais ou não, os órgãos representativos liderados pelos (2) acusados - o fato é que o comportamento de ambos excedeu os limites de suas atribuições puramente funcionais (BNM 429, fl.2992).

Outro argumento amplamente utilizado pelos procuradores foi a influência que grupos de esquerda teriam dentro do movimento estudantil. Conseqüentemente, para o $\mathrm{MP}$, as reivindicações dos estudantes não objetivavam, de fato, as questões estudantis e, orquestrados por grupos de esquerda, passaram a ameaçar a ordem e a segurança da nação. Em várias passagens dos processos judiciais, os procuradores procuraram evidenciar este envolvimento entre estudantes e os grupos de esquerda, através de testemunhas que apontavam os denunciados como militantes da Ação Popular (AP) e da Política Operária (POLOP). Na visão do MP, estas organizações eram "entidades subversivas com ampla penetração na classe universitária, sendo que através deles [universitários], é que este acusado aliciava seus colegas para ações subversivas (BNM, 429, fl.2999)". O procurador detalhava a influência destas organizações dentro das entidades estudantis:

$$
\begin{aligned}
& \text { Esta influência esquerdista é exercida através de } \\
& \text { organizações clandestinas que atuam seriamente no } \\
& \text { movimento estudantil, organizações estas como objetivos } \\
& \text { comuns, qual seja: promover a derrubada do atual governo }
\end{aligned}
$$


e regime, através da subversão e da destruição das instituições democráticas, com a conseqüente implantação do comunismo (BNM 429, fl.11).

A denúncia segue reafirmando a influência do Partido Comunista, Ação Popular (AP) e Politica Operária (POLOP) através da escolha de cargos dentro da UNE. Portanto, esse estudante era o revolucionário imbuído de ideais da esquerda para subverter a ordem e a segurança. Das palavras dos Procuradores:

Assim, as diretorias das entidades estudantis têm seus membros indicados pelo PARTIDO COMUNISTA, pela AÇÃO POPULAR ou pela POLÍTICA OPERÁRIA, que dispõem, antecipadamente, dos cargos através de acordos que celebram entre si, o que prova o objetivo comum (BNM 429, fl.12).

Confessando ser membro da AP (Ação Popular), órgão orientado pelo Partido Comunista, [o estudante] falou em todas as assembléias já referenciadas, cada vez acirrando mais os ódios e aumentando o clima de agitação estudantil (BNM 623, fl.4).

Os fatos narrados se desenvolveram dessa forma, sob a influência ideológica esquerdista, que se faz presente nas manifestações estudantis, o que não constitui nenhuma novidade (BNM 429, Denúncia, $s / n$ ).

Trata-se de elemento profundamente ligado aos movimentos de esquerda. A testemunha Eliomar afirma que o denunciado "conduziu o policial seqüestrado no Restaurante na UNB, sendo elemento de esquerda (BNM 5, Denúncia, $s / n)$.

(...) por fim, Marco, de tal gabarito nas hostes comunosubversivas que é um dos exigidos pelos seqüestradores em troca da vida do Sr. Embaixador Alemão; esses, pelo menos, constituindo a fina flor dessas atividades comunosubversivas, perenes, habituais, antes e depois deste 
processo, e que, data máxima vênia, o processado se acha prenhe; (BNM 429, fl.2454)"

Com o domínio das organizações de esquerda dentro do movimento estudantil, domínio esse apontado pelos procuradores, os processos judiciais acabaram por não demonstrar ação do Ministério Público preocupada em coibir as manifestações ligadas à questão educacional. $\mathrm{Na}$ verdade, o réu que o procurador apresentava nas denúncias e nas Razões da procuradoria era o militante estudantil avesso às diretrizes políticas e sócio-econômicas do governo vigente e muito pouco debatia questões ligadas ao âmbito estudantil.

Por exemplo, nos processos judiciais que trataram da distribuição de material com conteúdo dito subversivo, o MP investigou e processou os responsáveis pela distribuição de matérias consideradas subversivas por tratarem de temas como alusão à Guerra do Vietnã; ao imperialismo norteamericano; à situação dos trabalhadores na empresa Usiminas em Minas Gerais; Imperialismo na Amazônia, e etc. Dessa maneira, aos olhos do Ministério Público, o estudante militante, que deveria ser processado, era o que ameaçava a ordem e a segurança da sociedade. Das denúncias elaboradas pelo MP, sobressaía-se um estudante que atendia a uma agenda da esquerda subversiva:

(...) que a participação dos denunciados durante a passeata, tiveram por objetivo ameaçar a segurança interna, com intuito de produzir efeito no próprio âmbito nacional (BNM 690. Denúncia, $s / n$ ).

A ação dos estudantes se alicerça, a guerra revolucionária, em técnicas seculares, englobando várias atividades: aliciamento, propaganda, guerrilhas, etc., com o objetivo único de derrubar as elites dirigentes, principiando pela sua impopularidade e corrosão (BNM 354, fl.510).

Reafirmando a visão do MP, frente à militância estudantil, destaca-se o procurador-geral que, ao elaborar seu parecer para o recurso de uma ação de Apelação, depois de passados cinco anos da sentença condenatória, demonstrou que, de fato, a ação dos estudantes era considerada subversiva com indícios de repercussão além das questões estudantis: 
Por maior compreensão que se tenta com os jovens nos idos de 1967 quando a agitação estudantil era a tônica, envolvendo a gregos e troianos, o fato de que a sentença se lastreou, de fato, em provas e comportamento do acusado, após o relaxamento de sua prisão, comparecendo ao congresso de Ibiüna SP, razão pela qual foi condenado, conforme nos noticia o doc. Folha 195 nos esclarece que a sua política não era só estudantil (BNM 401, fl.260).

No BNM 429, a Procuradora Marly Valle Monteiro, ao fazer menção à entrevista televisa realizada com um dos denunciados, em seu parecer, para a manutenção da sentença condenatória da primeira instância, demonstrou claramente o conceito de inimigo da ordem que a Procuradoria nutria quanto ao comportamento dos estudantes denunciados. A Procuradora desferiu os seguintes argumentos:

(...) levado aos ouvidos da nobre gente mineira, pela boca de um comunistazinha, transvertido de representante do DCE.

Os conhecidos chavões ali se repetem, com monotonia, mas por isso mesmo, com sua inegável carga de maleficio, transbordando de verrinas assacadas contra o governo.

A morte do infeliz jovem Edson Luiz foi apenas pretexto. Por detrás do lamentável incidente, a ação solerte do comunismo aproveitou a ocasião, deflagrando, em todo o território nacional, manifestações desse tipo (BNM 429, fl.2997).

Do BNM 401, é possivel identificar todos os argumentos anteriormente comentados sobre a UNE quanto à ação de subversão da ordem apontada pelo MP:

$$
\begin{aligned}
& \text { Em poder do denunciados foram apreendidos } 59 \\
& \text { exemplares do panfleto que distribuíam no momento de } \\
& \text { suas prisões... } \\
& \text { O teor do panfleto é de natureza subversiva, uma vez que } \\
& \text { seus dizeres são desrespeitosos ao Governo, incitam de } \\
& \text { modo deliberado, à subversão da ordem politico-social }
\end{aligned}
$$


vigente, além de declarar, expressamente, a atividade $e$ fazer também propaganda de entidade sabidamente ilegal, ou seja, a UNE, constituindo, destarte também uma ameaça à Segurança Nacional (BNM 401, fl.4).

Em relação às sentenças absolutórias, a posição dos procuradores variou entre concordância e incredulidade. As ocasiões em que a procuradoria concordou com a sentença absolutória referem-se aos réus que não tiveram comprovadas participações no delito. Os argumentos do procurador do BNM 690 surpreendem pelo fato do MP não buscar a condenação acima de tudo, afinal, mesmo concordando que o apelante tinha um comportamento político subversivo na época do delito, isto não poderia ser considerado, de acordo com o Procurador, suficiente para comprovar que o denunciado cometera o ato de depredação. Finalizando sua argumentação o Procurador concluiu:

Logo, nesse campo de incertezas, num emaranhado de conjecturas, não posso, em sã consciência, com o zelo de quem busca a verdade na leitura dos autos, agasalhar as conclusões tiradas pela sentença recorrida." Ainda há a ressalva que mesmo que o co-réu tenha apontando Antônio como um dos participantes do ato de depredação da USIS [Serviço de Informações e Relações Culturais dos Estados Unidos], é necessário certo cuidado.

Porém, tratando-se do co-réu aquele declarante, indica a doutrina e a voz latente de nossos Tribunais, inclusive dessa Corte Castrense Superior, cautela na apreciação de sua força probatória (BNM 690, Fl. 374).

Marco Aurélio Vannucchi Leme de Mattos (2002, p.64), em sua pesquisa a respeito dos processos judiciais contra a ALN, apontou para algumas práticas utilizadas pela Procuradoria durante a tramitação dos processos que, também, puderam ser observadas nos onze processos judiciais do setor estudantil. Neste aspecto, destaca-se a questão da integração social do réu como um caminho para a absolvição. Para esse autor, os réus que comprovaram a não reincidência em atos subversivos e que se reintegraram à sociedade, dedicando-se à família e ao trabalho, tiveram mais chance de ter a absolvição requerida pela procuradoria (2002, p.66). 
Dos onze processos analisados, o caso mais evidente desta conduta do $\mathrm{MP}$, em absolver os que estavam se reintegrando socialmente, consta do BNM 623. Neste processo, o estudante José Pedro foi absolvido, apesar de reconhecida sua liderança nas reuniões junto a outros acusados e mesmo sendo comprovada sua participação nas manifestações julgadas como ilegais pelo Conselho de Justiça. Na leitura completa de todo o processo ficou evidente que, durante os três anos que durou o processo judicial, foi exaustivamente apontado, ora pela defesa, ora pela procuradoria e, por final, pelo Juiz Auditor, que José Pedro foi o único a comparecer em todas as sessões de julgamento. Alem disso, depois de três anos, o denunciado também comprovou sua boa conduta.

Outro aspecto interessante da atuação dos procuradores, diz respeito à concordância ou divergência em relação às sentenças do Conselho Justiça. Em grande medida, o Procurador-geral confirmou o parecer do procurador-militar em relação à sentença, afinal, todos os procuradores defendiam os mesmos interesses. Contudo, no BNM 429 a Procuradora-Geral não concordou com o desempenho do procurador da primeira instância e teceu inúmeras críticas à atuação. Através das argumentações da Procuradora-Geral ficou possivel, com maior detalhe, vislumbrar como o estudante denunciado estava sendo visto pelo MP naquele momento especifico.

Considerando que o procurador da primeira instância pediu a condenação para todos os denunciados no julgamento no Conselho de Justiça, a Procuradora-Geral, mesmo assim, apontou inúmeras falhas no desempenho do procurador militar em acusar. E, com um comentário sarcástico, começou por desqualificar o arrazoado submetido para o STM e, depois, passou a criticar as alegações finais:

$$
\begin{aligned}
& \text { (...) à medida que nos aprofundamos na leitura de seu } \\
& \text { arrazoado e, inclusive, nas Alegações Finais à que se } \\
& \text { reportou o digno Procurador Militar, não vemos como } \\
& \text { prestigiar o pedido de reforma da } v \text {. sentença de } 1^{a} \\
& \text { instância (BNM 429, fl.2989). }
\end{aligned}
$$

A procuradora-geral criticou o procurador da primeira instância, por este não ter recorrido da decisão do juiz auditor, que excluiu sete indiciados do 
processo, sob os fundamentos de que os fatos a eles correspondentes não estavam claramente circunstanciados pela acusação. Dessa maneira, segundo a procuradora-geral, o procurador militar estava "intimamente, [comungado] do mesmo entendimento", ou seja, da sua incapacidade de fundamentar fatos da acusação (BNM 429, fl.2990).

Há uma crítica que foi freqüentemente utilizada pela defesa, no entanto, empregada pela Procuradora-Geral para censurar a atuação de um dos seus. Diz respeito à circunstância de não ter, o MP, produzido novas provas na fase judicial, ou seja, ao final da instrução criminal, o órgão acusatório não trouxe novos elementos para fortalecer sua acusação. A Procuradora-Geral Marly Valle Monteiro enumera todos os artigos incriminatórios, invocados no processo, e depois critica:

No entanto, data vênia, o que vemos, nas Alegações Finais é um catálogo de crimes colocado ao lado de cada acusado, sem citar fatos, sem apontar ações enfim, sem trazer nada de novo para revelar suas culpas.

(..) em última análise, reflete a mesma fragilidade (BNM 429, fl.2990).

Mas adiante, ainda a mesma crítica:

Se o órgão acusatório não conseguiu trazer novos elementos de provas, limitando-se a citar artigos de Lei - seria, na verdade, uma demasia, revolver todo o processo, para catar, aqui e ali, o que pudesse servir de base para ensejar uma condenação (BNM 429, BNM 2992).

Após várias críticas ao desempenho do procurador da primeira instância, a Procuradora-Geral concorda com a sentença do Conselho de Justiça e enaltece a atuação do juiz auditor sem perder a oportunidade de elogiar sua decisão:

A v.decisão, ora recorrida, é uma das mais brilhantes que já tivemos oportunidade de analisar. São 30 páginas que 
espelham o inegável saber jurídico de seu culto e digno prolator-Dr. Mauro de Seixas Telles (BNM 429, fl.2991).

Um último aspecto importante que a Procuradora aponta, e que será abordado adiante na autuação da defesa, é o fato de considerar, o estudante um indivíduo ingênuo, propenso a se envolver em situações alheias à sua responsabilidade e capacidade de discernimento. Neste caso, a Procuradora contra rebate esse argumento tão comumente utilizado pelos advogados dos denunciados:

Jorge e Waldo são universitários politizados e, nem ao menos lhes socorre a atenuante da imaturidade intelectual. Já passaram dos 25 anos de idade e têm, por isso, verdadeira consciência dos fatos que estavam praticando (BNM 429, fl.2996).

O parecer da procuradora-geral confirmou todas as visões dos procuradores expostas anteriormente neste item. Conseqüentemente, os estudantes processados pelos crimes contra a segurança nacional, ao olhar da acusação, eram indivíduos totalmente conectados com grupos da esquerda comunista que almejavam subverter a ordem vigente. De todas as argumentações nada se encontrou, nas palavras dos procuradores, quanto ao estudante que militava em defesa de alguma causa ligada à educação, na verdade, considerando somente o discurso da acusação, os processos apresentam um rol de agitadores, pichadores e subversivos.

\subsection{Defesa}

Nas defesas dos onze processos analisados, todas demonstraram rigor técnico jurídico e empenho, por parte dos advogados, para buscar a absolvição dos estudantes processados. Diferentemente do que foi relatado por Tadeu Antônio Dix Silva (2007, p.344), em que muitos dos advogados de ofício, na defesa dos integrantes da Ala Vermelha, tiveram um desempenho medíocre e deixando transparecer a repulsa que tinham quanto a próprios defendentes. Nos casos aqui analisados, mesmo naqueles de réus defendidos por advogados de ofício, não foi identificado nenhum documento produzido com menor rigor se 
comparado com o restante da documentação, em que os advogados de defesa particulares defenderam a maioria dos réus.

Entretanto, toda a defesa, de maneira geral, valeu-se de argumentos para conseguir as absolvições dos seus defendentes, que nem sempre poderiam ser considerados argumentos fundamentalmente técnico-legais. Pode-se dizer que a maioria da defesa dos estudantes, procurava utilizar técnicas extralegais, dos tipos que foram aventados por Marco Aurélio Vannucchi Leme de Mattos. Neste caso, os argumentos extralegais mais utilizados foram referentes à integração social e à ingenuidade do réu (2002, p.66).

Exemplificando como se deu a defesa dos denunciados nos onze processos judiciais aqui analisados, pretende-se demonstrar o tipo de estudante que surge da documentação dos advogados, em contraponto ao perfil do estudante exposto pelos procuradores. Dessa maneira, foram destacados alguns argumentos mais comumente utilizados na defesa.

Nos processos, observa-se a estratégia da ingenuidade do denunciado como fator preponderante no seu envolvimento no delito. Algumas vezes, a defesa sequer procura descaracterizar o ocorrido, mas busca diminuir a responsabilidade do denunciado no ato.

Por exemplo, no BNM 354, o advogado procurou minimizar o ato de um dos estudantes, alegando que a ação de jovens não poderia ser considerada tão grave. Depois, argumentou que a perseguição moral do processo já foi capaz de punir o acusado. O protesto de solidariedade praticado pelo denunciado, ou seja, participar de um comício com seus colegas, não poderia afetar a Segurança Nacional, argumentando que o ato praticado por Antônio não se enquadraria nas ações citadas no $\S^{\circ}$ do art. $3^{\circ}$ do Decreto-Lei $314 / 6757$ que define Segurança Nacional, guerra revolucionária e conflito interno. Primeiramente, o defensor procurou minimizar o delito, alegando que a

57 Artigo $3^{\circ}$ A segurança nacional compreende, essencialmente, medidas destinadas à preservação da segurança externa e interna, inclusive a prevenção e repressão da guerra psicológica adversa e da guerra revolucionária ou subversiva.

$\S 3^{\circ} \mathrm{A}$ guerra revolucionária é o conflito interno, geralmente inspirado em uma ideologia ou auxiliado do exterior, que visa à conquista subversiva do poder pelo controle progressivo da Nação. 
manifestação pública, na quermesse, foi tão rápida que ninguém teria conseguido ser influenciado pelo discurso. Na verdade, conforme o advogado, o que de fato chamou atenção de todos na quermesse foi "a debandada geral que se registrou a seguir". Minimizando o ato considerado delito, a defesa diz:

Não resta dúvida que no protesto reivindicatório levado a efeito pelos acusados houve muito de "quixotada" muito de "romantismo" muito de falta do que fazer (BNM 354, fl. 566).

Na contramão do ideário da doutrina de segurança nacional, o defensor procurou demonstrar que as questões da Lei de Segurança Nacional deveriam ser direcionadas somente para assuntos mais complexos, como a segurança externa. Assim, o advogado argumentou:

Que país seria o nosso se um simples protesto de minguado grupo de estudantes fosse capaz de por em risco a segurança nacional? Qual o prejuízo trazido a nação pelo gesto do defendido na solidariedade com seus colegas?

NENHUM!

Seria inconcebivel admitir-se que o Brasil tivesse se prejudicado porque uns grupos de jovens, num gesto de impetuosidade temerária, levaram a efeito um protesto contra a prisão de colegas da classe universitária. E que tal fato teria posto em risco a segurança nacional.

Segurança Nacional é algo mais complexo, mais sério, de real magnitude, que não se abala com qualquer investida. $E$ seria minimizar a importância se ficássemos a todo instante relacionando fatos secundários, sem qualquer relevo, com a segurança nacional. A segurança nacional se relaciona com o Projeto Rondon, com a Transamazônica, com a indústria aeronáutica, com o alargamento da faixa do mar territorial para 200 milhas, com a ação do Ministério do Interior, do Ministério da Educação, do Ministério das Relações Exteriores projetando o Brasil além fronteiras. Atos que impeçam ou possam burlar a ação do Governo nessas e em outras áreas é que poderão ser considerados lesivos à 
segurança nacional, como bem sabe o Estado Maior das

Forças Armadas (BNM 354, fl.516).

Exaustivamente foi argumentado que as questões relativas à Segurança Nacional não deveriam abordar questões menores como as ações dos denunciados:

Segurança Nacional, MM. Juiz é muito mais que meia dúzia de panfletozinhos mal redigidos. O sentimento de segurança nacional toca a cada um de nós de modo intenso, de modo aconchegante, de modo salutar. Representa, em última análise, o dormir tranqüilo de nossos filhos, a certeza do deve cumprido de nossos pais, o trabalho e dedicação de nossos avós.

Não poderia nunca a Segurança Nacional, ser abalada por panfletos como os que fazem parte desses autos.

Porque analisados isolada ou conjuntamente, tais panfletos são, ainda que distribuidos fossem, absolutamente insignificantes para causar o mínimo transtorno à segurança nacional.

E como - indaga-se, poderiam tais panfletos perturbar ou produzirem efeito no âmbito interno do país? (BNM 354, fl.560).

De que forma estes mesmo panfletos seriam capazes de ameaçar ou pressionar o poder legalmente constituído? (BNM 354, fl.561).

Retomando a discussão a respeito dos condicionamentos do denunciado para a militância estudantil, destaca-se que alguns defensores balizaram o comportamento de seus defendentes na pouca idade e na condição estudantil para demonstrar a falta de capacidade de discernimento do acusado para evitar certas situações delituosas. Dessa maneira, a defesa apresenta um denunciado ingênuo, que foi seduzido por uma situação além de sua capacidade de avaliação.

A argumentação da defesa perpassa os valores familiares para tentar explicar como o denunciado acabou envolvido no delito. Para a defesa, os 
valores culturais e a hierarquia familiar do Acre, local de origem do estudante, eram diferentes do Distrito Federal, de tal forma que o denunciado foi influenciado pela "maior diluição e afrouxamento dos laços familiares" existentes na Capital Federal. O estudante veio do interior do país e foi influenciado pelos seus amigos "que lhes eram iguais na idade e aparentemente nos conhecimentos, sem perceber que estava sendo levado, paulatina, porém constantemente, para novas e perigosas fronteiras de luta contra as autoridades legitimamente constituidas" (BNM 354, fl.520).

Essa questão da ingenuidade foi identificada em outros processos, principalmente nos casos em que os denunciados não eram reincidentes. De fato, foi observado que em seis ${ }^{58}$ dos onze processos, os advogados utilizaram de tal argumento. Por exemplo, o advogado Osmar Alves de Melo que associa a ingenuidade à pouca idade do denunciado:

Inicialmente, é oportuno observar que, à época do evento, o acusado tinha 19 anos de idade, e, portanto, em fase de transição, sem adequada maturidade física, assim como psicológica e de idéias (BNM 354, fl.519).

Ora, o jovem é como o pássaro, cuja liberdade de vôo é o limite do horizonte. Toda liberdade fascina e por ela anseia e vive, sofre e morre, porque a liberdade condicionada, esta só é entendida pelo homem adulto, vergado pelo peso das responsabilidades, a quem a liberdade sem limites não passa de licenciosidade.

Nessas circunstâncias, o delito que the é atribuido dilui-se na sua incapacidade de compreender a suposta perturbação social resultante de seus atos (BNM 354, fl.520).

O acusado que à época contava com 20 anos de idade, era calouro na universidade, portanto, sem qualquer traquejo do ambiente acadêmico, mas mesmo assim não praticou qualquer ato contra a Segurança Nacional, apenas como informa mantinha relações de amizade com todos os

58 BNM 354, BNM 401, BNM 429, BNM 489, BNM 623 e BNM 695. 
colegas indistintamente, tanto que após os acontecimentos ajudou o Delegado Federal Dr. Jayme Rubstein (BNM 354, fl. 534).

O Advogado alega que o verdadeiro prejudicado foi o seu cliente que teve de trancar a matrícula do curso de engenharia na Universidade de Brasília.

(...) tão desambientado ficou que se viu na contingência de trancar a sua matrícula, deixando de prosseguir no Curso de Engenharia para se transformar num pacato comerciário, frustrado na sua perspectiva de futuro membro da elite técnica do país. Assim punido já está (BNM 354, fl.517).

A defesa argumenta como o fato de que o estudante confessou participar de uma manifestação reivindicatória e não de caráter de repúdio à ditadura. Entretanto, o acusado foi:

(..) enganado, iludido, e não sabia qual o verdadeiro conteúdo da manifestação, pois desconhecia não só a programação da mesa como a forma de sua divulgação, como ele mesmo o afirma: Conhece o boletim apreendido $e$ que foi mostrado pela policia, desconhecendo-lhe o teor.

Ele não disse, nem o faria, por respeito e talvez por temor aos mentores da manifestação, mas implicitamente se entende que compareceu à quermesse para fazer qualquer outra coisa, inclusive uma inocente "paquera", menos para participar de uma manifestação contrária ao governo (BNM 354, fl.521).

Para além da questão da imaturidade, o advogado argumenta que não havia provas da ligação do defendente com a produção e distribuição dos boletins. E se houve algum elemento que comprovasse tal fato, teria sido durante a confissão do acusado que, no entanto, o advogado alega ter se dado sob coerção:

A defesa apega-se aos fatos colhidos perante esse Egrégio Conselho, soberano e independente, imparcial e cujo espírito de justiça não é dado duvidar, porque os fatos colhidos na fase preliminar estão marcados pela ressalva do indiciado, 
segundo o qual teria sido ameaçado de privar-se de comer e beber, se não fizesse, segundo, alega, quando já se encontrava no interior da viatura que o levou preso, teria tido o seu braço torcido por alguém (BNM 354, fl.523).

De modo distinto da procuradoria, a defesa tenta desvincular o denunciado de grupos de esquerda e responsabiliza o envolvimento do estudante no delito por mero acaso:

Na espécie, trata-se de uma adolescente, confuso no turbilhão de novas idéias em que se viu envolvido, educado, todavia em (ilegivel), integrando sem dúvida um contexto social não só receptivo como até intransigentemente a favor do novo ideário político emergente movimento politico-militar de 1964, e o que é mais importante, sem nenhuma vinculação de natureza ideológica com grupos subversivos de qualquer uma das linhas em que estão divididos, sendo ainda de se ressaltar a sua convicção inabalável de que não estava praticando um ato delituoso contrário ao governo constitucional (BNM 354, fl.526).

Já ficou sobejamente provado que os acusados não tinham qualquer vinculação politica ou ideológica, que a manifestação foi puramente de caráter reivindicatório. Então porque se apenar os acusados, se para tanto inexistem suportes fáticos ou legais? (BNM 354, fl.568)

Outro recurso utilizado pelo Advogado Orlando Miranda Aragão foi tentar dimensionar o que ou quem foi afetado com a ação delituosa dos denunciados. Para a defesa, não houve notícia e declaração amplamente divulgada ao público, ou a uma faixa ponderável do público. Segundo Antony W. Pereira, foi comum os defensores questionarem o poder de amplitude da propaganda nos casos que envolveram a divulgação e distribuição de propaganda subversiva (PEREIRA, 2006, p. 123).

Os advogados dos onze processos judiciais, a exemplo da ProcuradoraGeral, rebateram a falta de produção de provas por parte da procuradoria e, também, questionaram o fato do uso do interrogatório policial para embasar a 
argumentação durante a fase judicial. Por exemplo, o advogado Geraldo Albano Safe Carneiro argumentou:

$$
\begin{aligned}
& \text { As alegações do Dr. Procurador Militar são assim, } \\
& \text { inteiramente destituídas de elementos probantes. A } \\
& \text { denúncia se ampara, única e exclusivamente, no } \\
& \text { depoimento de Marcos e já se provou, fartamente, que } \\
& \text { Marcos se equivocou dado ao peso da dificuldade em que se } \\
& \text { encontrou na prisão (BNM 354, fl.559). }
\end{aligned}
$$

De modo geral, a defesa procurou apresentar um estudante ingênuo e seduzido pelo meio acadêmico que o impulsionou ao exercício de atividades subversivas, alheias a sua conduta moral. Tentando redirecionar a atenção da repressão, os advogados insistiram no fato que a Segurança Nacional deveria tratar de assuntos maiores, tais como a segurança externa.

\subsection{Sentenças}

As vinte e três condenações impostas pelos Conselhos de Justiça nas Auditorias Militares variaram de seis meses a quase três anos de reclusão, ${ }^{59}$ sendo que a maioria (52\%) foi de dois a três anos.

$\mathrm{Na}$ maioria das sentenças condenatórias, os juízes fundamentaram suas decisões com argumentos técnicos legais, procurando explicar porque o referido artigo incriminatório sustentava tal denúncia. Eventualmente, em algumas sentenças, os juizes também apresentaram respostas diretas às argumentações da defesa, por não concordarem com o embasamento legal utilizado pelos advogados. Como verificado no BNM 5, os advogados alegaram que o seqüestro de policial acontecera fora da hora de expediente, de forma que não poderia ser considerada como uma ação contra um funcionário público.

\footnotetext{
${ }^{59} \mathrm{Em}$ algumas sentenças os réus foram condenados à reclusão ou a detenção. Assim, torna-se importante esclarecer a diferença entre Detenção e Reclusão:

A pena de reclusão é severa, e deve ser cumprida em regime fechado, numa penitenciária, em regime semi-aberto ou aberto. A pena de detenção é menos rigorosa, e é cumprida em regime aberto ou semi-aberto, exceto quando há a necessidade de transferi-la para regime fechado. A detenção é, também, uma forma de prisão preventiva. Em regime semi-aberto, a execução da pena se dá em colônia penal agrícola, industrial ou em algum outro estabelecimento parecido. Em regime aberto, cumpre-se a pena em casa de albergado ou outro lugar adequado para isso. (http://daleth.cjf.gov.br/vialegal/? CodADireito=16, acessado em dezembro de 2007).
} 
Outro argumento, apontava que o seqüestro não tivera motivação política. Os juízes do Conselho de Justiça antes de proferirem a sentença rebateram as argumentações da defesa:

(...) foi argüida a incompetência deste Juizo Militar, argumentando que a vítima não se encontrava no exercício de função no local da ocorrência. Em primeiro lugar, a norma penal, não exige a qualidade do funcionário público do ofendido e muito menos que se encontre em exercício de função, pode mesmo ser um civil (BNM 5, fl. 917).

O Conselho alegou, também, que não se poderia negar a inocorrência do móvel politico do crime a partir do momento que a liberação do seqüestrado passou ser condicionada à liberação dos estudantes presos (BNM 5, fl. 917).

Os três motivos apontados pelos juízes, para as condenações, nos onze processos judiciais foram, em primeiro, a comprovação da participação dos réus, nos delitos, através da apreciação das provas e, também, pelas confissões dos próprios réus; em segundo, a prova de materialidade que deu sustentação legal para os juízes condenarem os estudantes do BNM 535, por porte de material explosivo; e, por último, os juízes, em duas condenações (BNM 489 e 690), nortearam suas decisões pelo histórico de militância dos réus.

Esclarecendo como de fato aconteceu a condenação baseada nos antecedentes dos réus, primeiro destaca-se o caso do BNM 690. Neste BNM, foi verificado que o Conselho de Justiça condenou o estudante pela participação na depredação do prédio do Serviço de Divulgação e Relações Culturais dos EUA (USIS) porque, além da confissão de um co-réu, foi considerado que o acusado tinha perfil propenso à prática de atividades subversivas. A sentença fazia menção à vida pregressa do acusado, indicando que o estudante, após ingressar na universidade, continuava participando do movimento estudantil secundário como vice-presidente do Centro dos Estudantes Secundários do Ceará.

Das palavras do juiz auditor, o reconhecimento da militância do acusado: 
Isto importa dizer que [Antonio], embora já estivesse passado no vestibular da Faculdade, ainda estava umbilicalmente ligado ao órgão estudantil do ciclo que estava saindo e do qual era um de seus líderes (BNM 690, fl. 338).

De maneira similar, a estudante Helenira foi condenada por ser "pessoa de intensa atividade nos movimentos estudantis, e de alta periculosidade" (BNM 489, fl.174). Os juizes devem ter concluído que Helenira possuía tal potencialidade criminosa através do relatório do DOPS anexado aos autos:

Segundo informações reservados do II Exército, de 9/5/68, que Helenira, aluna universitária em São Paulo, é ativa fanática em subversão, consta ser filha de ativo comunista de Palmital - SP.

Assinou, juntamente com outros estudantes, membros do GRÊMIO, manifesto para o mesmo, intitulado Chapa "Frente de Trabalho", arquivado neste Serviço, em 21/8/68.

Indiciada no $2^{\circ}$. Flagrante, juntamente com outros estudantes, por ter participado do XXX Congresso da extinta UNE, no Municipio de Ibiúna, em 12/10/68. Enquadrada na Lei de Segurança Nacional.

Em 18/11/68, foi iniciado o sumário de culpa de Helenira e de outros, estudantes, na $2^{a}$. Auditoria de Guerra, já que estão sendo processados nos têrmos do artigo 36, da LSN.

STM em 29/11/68 - negaram vários "hábeas corpus" para os processados nos artigos $56^{\circ}$ e $54^{\circ}$ da LSN - como figura Helenira.

- ordem de soltura para vários estudantes, inclusive Helenira que se encontrava no Presídio de Mulheres. Conforme publicação na Imprensa em 11/12/68.

3/3/69 - A Justiça Militar enviou para D.O.P.S. o Mandato de Prisão contra vários estudantes, incluindo Helenira. 


\section{Documento Reservado da SECRETARIA DA SEGURANÇA}

PÚBLICA/DEPENDÊNCIA: SERVIÇO DE INFORMAÇÕES:

DOPS. São Paulo, 10 de julho de 1969 (BNM 489, fl.35).

As sentenças absolutórias foram embasadas, principalmente, na dificuldade que a procuradoria teve em comprovar qual a participação de fato de cada estudante nos delitos. Por exemplo, no BNM 5, referente ao seqüestro do policial, somente 2 dos 12 acusados foram condenados, sendo que os outros não tiveram o delito comprovado pela Procuradoria. Os juízes consideraram que os estudantes até poderiam estar no local do seqüestro, mas não foi possível comprovar a participação efetiva de cada um no fato. As acusações foram consideradas muito generalizadas, vagas e com pouca consistência.

Outro aspecto relevante, nas absolvições, é a integração social do acusado. Durante a acusação, os procuradores consideravam positivamente a conduta de integração social por parte dos acusados. No momento da sentença, os juízes auditores também apreciavam a melhora da conduta social do réu, desde o momento do delito até a data da sentença. Como verificado nas palavras do juiz auditor por ocasião da sentença:

Os demais acusados não têm contra si provadas suas acusações sendo que alguns deles são hoje pessoas integradas no seio da sociedade, o que se pode ver dos documentos juntos pela defesa aos autos (BNM 429, fl.2435).

No BNM 489, o acusado Rafael foi absolvido por sua boa conduta depois dos fatos e pela ausência de ocorrência em sua ficha criminal. Na sentença, antes da exposição do veredicto, o Conselho apontou uma das alegações da defesa para corroborar com decisão do Conselho em absolver o acusado:

\section{(...) agora formado e pai de família, interessa à justiça e à própria segurança nacional que permaneça, como se acha integrado no labor construtivo da sociedade (BNM 489, fl. 169).}

Nestes dois BNMs é comprovado, conforme argumentação de Marco Aurélio Vannucchi Leme de Mattos (2002), que os Conselhos absolviam os 
acusados que apresentassem boa conduta e uma vida útil depois da ocorrência do delito e, também, aqueles que mostravam arrependimento.

Em todas as sentenças analisadas, os juízes apresentaram os motivos para a tomada de decisão, discordando quando necessário da Procuradoria. Em alguns casos, lançaram críticas até mesmo ao desempenho da acusação. Como comentado, também procuraram rebater as argumentações da defesa, quando as alegações abordavam o desempenho do Conselho de Justiça.

O estudo da atuação da procuradoria, da defesa e dos juízes auditores, demonstrou, pelo menos dentro do universo judiciário, que o governo na questão da repressão judicial era conduzido por parâmetros legais apoiado em Atos Institucionais e Leis repressivas para a sustentação e manutenção do regime militar. Deste modo, ao mesmo tempo em que o Estado combatia a oposição lançando mão de uma série de práticas discricionárias, como a tortura, o assassinato, o seqüestro e o "desaparecimento", também utilizava todo um rigor jurídico fundamentado nas normas legais criadas pelo próprio governo militar para processar e punir (MATTOS, 2002, p.7). 


\section{Considerações Finais}

Este trabalho apresentou quem foi o estudante militante processado durante o regime militar, através da elaboração do perfil daqueles denunciados nos processos judiciais que atingiram a esfera do STM.

Esses processos judiciais pertenceram à esfera da Justiça Militar, em conseqüência da instauração do AI-2, que transferiu para a Justiça Castrense a responsabilidade de processar e julgar os crimes contra a segurança nacional.

O perfil dos estudantes foi determinado a partir da análise do acervo do BNM. Inicialmente, foram considerados os estudantes denunciados em todos os processos judiciais do acervo. Em seguida, foram analisados os dados de sessenta e nove estudantes relacionados em onze processos judiciais.

Primeiramente, o perfil dos estudantes foi elaborado a partir da listagem e análise do universo estudantil existente nos processos judiciais. Desta análise, conclui-se que a maioria dos estudantes denunciados pertencia ao sexo masculino e tinha mais de 21 anos, sendo que havia uma participação relevante $(16 \%)$ de estudantes com idade superior a 25 anos. Isso demonstra que ser jovem não era condição fundamental para o estudante envolver-se na militância. Uma pequena parte dos estudantes desempenhava uma segunda atividade, além de estudar. Dentre os estudantes que figuraram nos processos classificados no rol das atividades estudantis e de atividades de outros setores, a grande maioria foi arrolada, primeiramente, em processos estudantis, passando em seguida para outras atividades, como as organizações de esquerda. Essa informação pode comprovar que a militância, nas organizações de esquerda, começou, em grande medida, dentro dos redutos universitários.

Em relação aos trâmites dos processos, foi observado, em todas as etapas do julgamento, pelo menos nos discursos, o rigor em usar de técnicas jurídicas obedecendo ao Código da Justiça Militar e à Lei de Segurança Nacional vigentes no período. Outro aspecto relevante na dinâmica processual refere-se ao fato de que todas as ações investigadas envolvendo estudantes, apoiavam-se em legislação na qual eram tipificadas como delito criminal. Dessa 
maneira, conclui-se que o regime militar conseguiu abarcar, por meio das leis, todas as ações que representassem potencial ameaça à ordem vigente.

$\mathrm{Na}$ maioria dos casos analisados, os procuradores e os advogados construíram uma visão antagônica do estudante denunciado, convergindo em raras situações. Para a procuradoria, o estudante denunciado era o individuo subversivo interagindo com grupos organizados de esquerda e com o principal interesse de subverter a ordem vigente. Eram estudantes que deixaram de lutar pelos ideais educacionais para se envolver em militância que colocava em risco a segurança nacional.

Para os advogados de defesa, o estudante denunciado era refém de sua condição de imaturidade e, deslumbrado com o mundo acadêmico, passava a participar ingenuamente de atos subversivos. Na maioria das defesas, não houve a tentativa de provar que o estudante não participou do ato, mas de qualificar a ação como resultado de sua ingenuidade e, portanto, imaturidade. Não obstante, houve algumas argumentações de cunho técnico legal, em que a defesa destacou que o tipo de delito praticado não poderia de fato ser considerado crime contra a segurança nacional. Conseqüentemente, na argumentação da defesa, a Lei de Segurança Nacional somente deveria ser invocada em questões mais importantes do que as ações de alguns estudantes.

O ponto de convergência entre acusação e defesa foi observado, de forma geral, em situações nas quais o estudante militante demonstrou que poderia se reintegrar socialmente e deixar de cometer atentados contra a segurança nacional. Para os juízes auditores, o fato de o estudante demonstrar boa conduta durante o julgamento do processo também foi fundamental para garantir a absolvição. Ou seja, o militante subversivo, aos olhos da acusação e do juiz auditor, era um indivíduo que poderia ser transformado em cidadão responsável.

Devido às restrições de tempo para o desenvolvimento da dissertação, não foi possivel, conforme ressaltado, analisar inteiramente mais que onze processos judiciais do acervo do Projeto BNM. Ainda assim, espera-se que este trabalho seja uma contribuição com os estudos que analisam as relações sociais e institucionais do período em questão. Espera-se, também, que possa 
motivar outros pesquisadores a retomar a análise dos processos e dos recursos que foram utilizados tanto para acusar como para defender os estudantes em seus julgamentos. 


\section{Referências Bibliográficas}

\section{Artigos}

ALCÂNTARA, M. de Lourde Beldi de. In: Editorial. Revista do Núcleo Interdisciplinar do Imaginário e Memória - LABI. Instituto de Psicologia da Universidade de São Paulo - IP - USP, № 12 - 2006, 1ㅇsemestre.

AQUINO, M. A. 1964: Um olhar retrospectivo. In: Revista Tempo Brasileiro, 158: $37 / 57$, jul. - set, 2004, p.37-58.

AUGUSTO, M.H.O. Retomada de um legado Intelectual. Marialice Foracchi e a sociologia da juventude. In: Tempo Social. Revista de Sociologia da Usp. São Paulo: v. 7 №2, novembro de 2005, p.11- 33.

BITTENCOURT DA SILVA, R. A construção simbólica do "populismo brizolista" operada pelo Jornal do Brasil. In: Revista Comum 21, julho/dezembro 2003, vol.8, no21, pp.103 a 125.

BODSTEIN, R. C. de A. Social sciences and public health: new issues, new approaches. Cad. Saúde Pública: Rio de Janeiro, v. 8, n. 2, 1992.

BUCK. R.C. O "Habeas Corpus". Cadernos de Direito. In: Cadernos do Curso de Mestrado em Direito da Universidade Metodista de Piracicaba; 2001; UNIMED; vol. 1; No1; pp.201- 208, 1676-529X; Impresso.

CARDOSO, I. DE A.R. 1968. O movimento estudantil e a passagem para a luta armada. São Paulo, FFLCH, s.d., mímeo.

CARDOSO, I. DE A.R. A dimensão trágica de 1968, In: Teoria e Debate, Revista trimestral do Partido dos Trabalhadores. São Paulo, 30trimestre, 1993, n0 22, pp. 59-64.

CARDOSO, I. DE A.R. Maria Antônia. A interpretação de um lugar a partir da dor. In: Tempo Social. Revista de Sociologia da USP. São Paulo, out., 1996, vol.8, n.2, pp. 1-10.

CARDOSO, I. DE A.R. Memória de 68: terror e interdição do passado. In: Tempo Social. Revista de Sociologia da Usp. São Paulo: 2(2): 101-112, 2. sem.1990.

CARRANO, P. C. R. Jovens e Participação Política. In: Marilia Pontes Spósito. (Org.). Juventude e Escolarização. 1 ed. Brasília: MEC/Inepe/Comped, 2002, v. 1 , p. $185-202$.

COSTA, C.M.L. Acesso à informação nos arquivos brasileiros: retomando a questão. In: Estudos Históricos, Rio de Janeiro, n. 32, 2003, p.178-188.

FICO, C. Versões e Controvérsias sobre 1964 e a Ditadura Militar. In: Revista Brasileira de História, São Paulo, n.47, 2004, p.29-60.

FRAGOSO, H C. A Lei de Segurança Nacional. In: Revista de Direito Penal de 
Criminologia, no35. Forense, Rio de Janeiro, jan-jun, 1983, p.60-69.

KAUCHAKJE, S. Pedagogia e movimentos sociais: uma relação significativa na ampliação da cidadania e da democracia no Brasil In: Pedagogia em debate ed.Curitiba: FCHLA/PPS-ED Mestrado em Educação/Pedagogia, 2002, v.1, p.129.

MARTINS, S. H. Z. A Representação da pobreza nos registros de repressão: Metodologia do Trabalho Com Fontes Criminais. In: Revista de História Regional 3(1): Verão 1998.

MORAES, J.Q. A Mobilização Democrática e o Desencadeamento da Luta Armada no Brasil em 1968: notas historiográficas e observações criticas. In: Tempo Social. Revista de Sociologia da USP. São Paulo, 1(2): 135 -158, $2^{\circ}$ sem. 1989.

PRIORI, A. A. Repressão e violência política, no Brasil e Argentina (1964-1985) Trabalho apresentado na IX Jornadas Interescuelas/Departamentos de História. Córdoba: Universidad Nacional Córdoba / Argentina, no dia 25 set. 2003.

REIS FILHO, D.A. 1968, o curto ano de todos os desejos. In: Tempo Social. Revista de Sociologia da Usp. São Paulo: 10(2): 25-35, outubro de 1998.

SESTINI, D. P. R. O apoio civil à intervenção militar de 1964: a questão das entidades femininas em São Paulo. In: Simpósio Nacional da Associação Nacional de Professores Universitários de História-ANPUH, 2007, São Leopoldo. História e Multidisciplinaridade: territórios e deslocamentos, 2007.

SILVA, A. M. D. da. Ditadura militar e justiça castrense no Brasil: espaço de legitimação política e de contradições. In: I Encontro Nacional da ASSOCIAÇÃO BRASILEIRA DE ESTUDOS DE DEFESA - ABED, 2007, São Carlos - SP. Anais do I Encontro Nacional da ABED, 2007b.

SPOSITO, M. P. A produção do conhecimento sobre juventude na área da educação. International Studies on Law and Education. São Paulo: v. 4, 2001 p. 37-55.

TEIXEIRA DA SILVA, Francisco C. Politica E Memória na América Latina: A Luta Contra o Esquecimento do Tempo Presente na Argentina, Uruguai E Brasil. In: I Fórum de Pesquisa PGH-UEM/UEL, 2001, p. 310-314.

\section{Livros e capitulos de livros}

ACOSTA, W. P. O processo penal. 13a. ed. Rio de Janeiro: Editora do autor, 1978.

ALVES, M. H. M. Estado e oposição no Brasil: 1964-1984. Petrópolis: Vozes, 1984.

ALVES, M.M. 68 mudou o mundo. A explosão dos sonhos e a guinada conservadora num ano que valeu por décadas. Rio de Janeiro: Nova Fronteira, 1993. 
AQUINO, M. A. A especificidade do regime militar brasileiro: abordagem teórica e exercício empírico. In: REIS FILHO, D. A (org.). Intelectuais, história e política: séculos XIX e XX: Rio de Janeiro: 7 Letras, 2000, p. 271-289.

ARQUIDIOCESE DE SÃO PAULO. Brasil: Nunca Mais. 18 ed. Petrópolis: Vozes, 1986.

BACELLAR, C. Uso e mau uso dos arquivos. In: Pinsky, B.C. (org). Fontes históricas. São Paulo: Contexto, 2005.

BANDEIRA, M. O Governo João Goulart: As lutas sociais no Brasil (19611964). Rio de Janeiro: Civilização Brasileira, 1978.

BEOZZO, J. O. Os cristãos na universidade e na politica. Petrópolis: Vozes, 1984.

BERG, C. Mecanismos do silêncio: expressões artísticas e censura no regime militar (1964-1984). São Carlos: EdUFSCar, 2002.

BOURDIER, P. A juventude é apenas uma palavra. In: BOURDIEU. P. Questões de Sociologia. Rio de Janeiro: Marco Zero, 1983, p.112-121.

BRANCO, C.C. Os militares no poder. O Ato 5. Rio de Janeiro: Nova Fronteira, 1978, vol.2.

BRESSER-PEREIRA, L. C. As Revoluções Utópicas dos Anos 60. 3ạed. São Paulo: Editora 34 Ltda., 2006.

BRITTO, S. (org.), Sociologia da Juventude. V.1. Rio de Janeiro: Zahar, 1968.

BURKE, Peter. Abertura: A nova História, seu passado e seu futuro. In: A Escrita da história: novas perspectivas. São Paulo: Unesp, 1992.

CARDOSO, C.F. e BRIGONOLI, H. P. Os métodos da História: introdução aos problemas, métodos e técnicas da história demográfica, econômica e social. Rio de Janeiro: Graal, 1987, 40 ed.

CARDOSO, F. H. \& FALETTO, Enzo. Dependência e desenvolvimento na América Latina: ensaio de interpretação sociológica. 6. ed. Rio de Janeiro: Zahar, 1981.

CARDOSO, F. H., Associated dependent development: theorethical and practical implications. In: Authoritarian Brazil (A. Stepan, ed.), pp. 142-178, New Haven: Yale University Press, 1973.

CARDOSO, I. DE A.R. Maria Antonia: O edifício de no294. In: MARTINS FILHO, J. R. (org). 1968. Faz 30 anos. Campinas, São Carlos: Mercado das Letras e EDUFSCar, 1998, p.27-48.

COGAN, A. Crimes contra a Segurança Nacional. Comentários, Legislação e Jurisprudência. Revista dos Tribunais: São Paulo, 1976.

DIAS, R. Os trabalhadores e a esquerda na resistência à ditadura militar: a greve geral de outubro de 1968 em Maringá. In: DIAS, R.; GONÇALVES, J. H. R. Maringá e o norte do Paraná: estudos de história regional. Maringá: EDUEM, 
1999, p. $179-219$.

DIAS, R. Uma Universidade de ponta cabeça. Maringá: Clichetec, 2000.

DREIFUSS, R. A. 1964: A conquista do Estado - ação política, poder e golpe de classe. Petrópolis: Vozes, 1981.

FAUSTO, B. Crime e Cotidiano. A criminalidade em São Paulo, 1880-1924. São Paulo. EDUSP.

FAUSTO, B. Historia do Brasil. 12 ed. São Paulo: Editora da Universidade de São Paulo - Edusp, 2004.

FÁVERO, M. L. A universidade brasileira em busca de sua identidade. Petrópolis, Vozes, 1977.

FÁVERO, M. L. UNE em tempos de autoritarismo. Rio de Janeiro: UFRJ, 1994.

FERNANDES, F. A questão da USP. São Paulo, Brasilense, 1984.

FERNANDES, F. Universidade brasileira: reforma ou revolução? São Paulo: Alfa-Ômega, 1979.

FERREIRA, C. L. Crimes contra a Segurança do Estado. Rio de Janeiro: Líber Júris Ltda., 1982.

FERREIRA, P. Teoria e prática do habeas corpus. 4.ed. São Paulo: Saraiva, 1988.

FICO, C. Como eles agiam: os subterrâneos da ditadura militar - espionagem e polícia política. Rio de Janeiro: Record, 2001.

FORACCHI, M.M. A juventude na sociedade moderna. São Paulo: Livraria Pioneira, 1972.

FORACCHI, M.M. Os estudantes e a transformação da sociedade brasileira. São Paulo, Nacional, 1977.

GABEIRA, F. O que é isso companheiro? São Paulo: Companhia da Letras, 1996.

GOMES, A. C. 2001. O populismo e as Ciências Sociais no Brasil: notas sobre a trajetória de um conceito. In: FERREIRA, J. (org.). 2001. O populismo e sua história - debate e crítica. Rio de Janeiro: Civilização Brasileira.

GORENDER, J. O combate nas trevas. A esquerda brasileira: das ilusões perdidas à luta armada. São Paulo, Ática, 1987.

GROPPO, L.A. Juventude. Ensaios sobre Sociologia e História das Juventudes Modernas (Coleções Enfoques. Sociologia). Rio de Janeiro: DIFEL, 2000.

HELLER, I. M. Resistência democrática: A repressão no Paraná. Curitiba: Paz e Terra/ Secretaria da Cultura do Paraná, 1988. 
IANNI, O. O Jovem Radical. In: Sociologia da Juventude. v.1 BRITTO, S. (org), Rio De Janeiro: Zahar, 1968.

LEMOS, R. (org). Justiça fardada: O General Peri Belivaqua no Superior Tribunal Militar (1965-1969). Rio de Janeiro: Bom Texto, 2004.

MACIEL, W.A. O capitão Lamarca e a VPR. Repressão judicial no Brasil. São Paulo: Alameda, 2006.

MARGULIS, Mario \& URRESTI, Marcelo. "La juventud es más que una palabra". In: Margulis, M. (org.). La juventud es más que una palabra. Buenos Aires, Biblos, 1996.

MARTINS FILHO, J. R. Movimento estudantil e ditadura militar. (19641968). Campinas: Papirus, 1987.

MARTINS FILHO, J. R. O movimento estudantil na conjuntura do golpe. In: TOLEDO, C. N. (org). Visões críticas do Golpe: Democracia e Reformas no Populismo. Campinas: Unicamp, 1997, p.75-83.

MARTINS FILHO, J. R. Os estudantes nas ruas, de Goulart a Collor. In: MARTINS FILHO, J. R. (org). 1968. Faz 30 anos. Campinas, São Carlos: Mercado das Letras e EDUFSCar, 1998, p.11-26.

MARX, K. \& ENGELS, F. A ideologia alemã. São Paulo: Hucitec, 1984.

MATTOS, M. A. V.L. de; SWENSSON Jr., W. C. Contra os inimigos da ordem: a repressão politica do regime militar brasileiro (1964-1985). Rio de Janeiro: DP\&A, 2003.

MENDES, M. Mackenzie no espelho. São Paulo: Mackenzie, 2007.

Mitra ARQUidiocesana de SÃo PAUlO. Perfil dos Atingidos. Petrópolis: Vozes, 1987.

NORONHA, E. M. Curso de direito processual penal. 11. ed. São Paulo: Saraiva, 1979.

O’DONNELL, G. Reflexões sobre os estados burocrático-autoritários. São Paulo. Vértice/Revista dos Tribunais, 1987.

OLIVEIRA, E. R. de. As Forças Armadas: politica e ideologia no Brasil (19641969). Petrópolis: Vozes, 1976.

PELEGRINI, S. C. A. A UNE nos anos 60: utopias e práticas políticas no Brasil. Londrina: Eduel, 1998.

PEREIRA, A.W. O papel dos advogados de defesa na Justiça Militar Brasileira, 1964-1979: Redefinindo o crime político. In: MARTINS FILHO, J. R. (Org.) O golpe de 1964 e o regime militar: novas perspectivas. 1. ed. São Carlos: EDUFSCar, 2006.

POERNER, A. J. O poder jovem. 2. ed. Rio de Janeiro: Civilização Brasileira, 1979. 
PRIORI, A.; POMARI, L. R. Ditadura Militar: repressão e violência política contra os movimentos sociais. In: VILALLOBOS, J. A. (org). Geografia e movimentos sociais. Maringá: PPG, 2001.

REIS FILHO, D. A. 2001. O colapso do colapso do populismo ou o propósito deu uma herança maldita. In: FERREIRA, J. (org.). 2001. O populismo e sua história - debate e crítica. Rio de Janeiro: Civilização Brasileira.

REIS FILHO, D. A. A revolução faltou ao encontro (os comunistas do Brasil). São Paulo, Brasilense, 1989.

REIS FILHO, D. A; RIDENTI, M; MOTTA, R. P. S. (orgs.). O golpe militar e a ditadura: 40 anos depois - (1964-2004). Bauru: EDUSC, 2004.

REIS FILHO, D. GASPARI, E (org.). Versões e Ficções. O seqüestro da história. $2^{a}$ ed. São Paulo: Fundação Perseu Abramo, 1997.

RIDENTI, M. Intelectuais, estudantes e artistas: Paris, 1968. In: REIS FILHO, D. A. (org). Intelectuais, história e política: séculos XIX e XX. Rio de Janeiro: Sete Letras, 2000.

RIDENTI, M. O Fantasma da revolução brasileira. São Paulo: Unesp, 1993.

RIDENTI, M. Que história é essa? In: REIS FILHO, D. A. et al.(org). Versões e ficções: O seqüestro da história. $2^{a}$ ed. São Paulo: Fundação Perseu Abramo, 1997.

SANFELICE, J. L. Movimento estudantil: a Une na resistência ao golpe de 64 . São Paulo: Cortez/Autores Associados, 1986.

SILVA, M. (org.) Brasil, 1964/1968: a ditadura já era ditadura. São Paulo: LCTE, 2006.

SIRKIS, A. Os Carbonários. 14ª Ed. Rio de Janeiro: Record, 1998.

SKIDMORE, T. Brasil: de Getúlio a Castelo. $10^{\text {a }}$ ed. Rio de Janeiro: Paz \& Terra, 1996.

SOUZA, L. A. G. A JUC: os estudantes católicos e a politica. Petrópolis: Vozes, 1984.

STEPAN, A. C. Os militares na política: as mudanças de padrões na vida brasileira. Rio de Janeiro: Artenova.

STOPPINO, M. Poder. In: BOBBIO, N. et alli. Dicionário de política. Tradução: Carmem C. Varriale e outros. Brasília: Unb, 1986, p. 933-943.

TELES, J. (org.). Mortos e desaparecidos políticos: reparação ou impunidade? São Paulo: Humanitas FFLCH/USP, 2001.

THOMPSON, E. A formação da Classe Operária Inglesa, Rio de Janeiro, Paz e Terra, 1987.

VALE, O.T. O Supremo Tribunal Federal e a Instabilidade PolíticoInstitucional. Rio de Janeiro: Civilização Brasileira, 1976. 
VALLE, M.R. 1968: O diálogo é a violência. Movimento Estudantil e ditadura militar no Brasil. Campinas: Unicamp, 1999.

VENTURA, Z. 1968. O ano que não terminou: a aventura de uma geração. Rio de Janeiro: Círculo do Livro, 1998.

WEFFORT, F. O populismo na politica brasileira. Rio de Janeiro: Paz e Terra, 1978.

WESCHLER, L. Um milagre, um universo. O acerto de contas com os torturadores. São Paulo. Companhia das Letras, 1990.

ZANETI, H. Juventude e Revolução. Uma investigação sobre a atitude revolucionária juvenil no Brasil. Brasília: Universidade de Brasília, 2001.

\section{Teses, dissertações e monografias.}

AQUINO, M.A. Caminhos Cruzados, Imprensa e Estado Autoritário no Brasil (1964-80). Tese de Doutorado. Programa de Pós-graduação em Sociologia da Faculdade de Filosofia, Letras e Ciências Humanas da Universidade de São Paulo, São Paulo, 1994.

CARDOSO, L.L. Poder e Contrapoder: Militares e Historiadores Disputam a Memória e a Historia do Regime de 1964. Tese de Doutorado. Programa de Pósgraduação em Sociologia da Faculdade de Filosofia, Letras e Ciências Humanas da Universidade de São Paulo, agosto de 2003.

LIMA, R. R. Nunca é tarde para saber: histórias de vida, história da guerrilha. Tese de Doutorado. Faculdade de Filosofia, Letras e Ciências Humanas. São Paulo. USP. 1998.

MATTOS, M.A.V.L. Em nome da segurança nacional: os processos da Justiça Militar contra a Ação Libertadora Nacional (ALN), 1969-1979. São Paulo: Dissertação de Mestrado em História Social, FFLCH-USP 2002.

PIMENTA, M.de M. Jovens em transição. Um estudo sobre a transição pra a vida adulta entre estudantes universitários em São Paulo. Dissertação de Mestrado. Programa de Pós-graduação em Sociologia da Faculdade de Filosofia, Letras e Ciências Humanas da Universidade de São Paulo, agosto de 2001.

PRIORI, A. A. A revolta camponesa de Porecatú: A luta pela defesa da terra camponesa e a atuação do Partido Comunista Brasileiro (PCB) no campo (19421952). 2000. Tese de Doutorado. Faculdade de Ciências Sociais e Letras. Universidade Estadual Paulista. Assis, São Paulo. UNESP. 2000.

PRIORI, A. A. Legislação Social e Sindicalismo: Um estudo sobre os trabalhadores rurais do Norte do Paraná (1956-1963). Dissertação de Mestrado. Faculdade de Ciências Sociais e Letras. Universidade Estadual Paulista, Assis, São Paulo. UNESP. 1994.

REZENDE, D. S. A História na Mão: Periódicos universitários discentes paulistas entre 1964-1979. Universidade de São Paulo, Tese de Doutorado. Programa de Pós-graduação em Sociologia da Faculdade de Filosofia, Letras e 
Ciências Humanas da Universidade de São Paulo, maio de 2003.

SILVA, T. A. D. Ala Vermelha: revolução, autocrítica e repressão judicial no Estado de São Paulo (1967-1974). Tese de Doutorado. Programa de Pósgraduação em Sociologia da Faculdade de Filosofia, Letras e Ciências Humanas da Universidade de São Paulo, São Paulo, 2007.

\section{Documentos eletrônicos}

DIAS, R. Elementos para uma História da Ação Popular no Paraná. <http://www.uepg.br/rhr/v4n2/reginaldo.htm acessado em 18 ago.2001>

FICO, C. Versões e controvérsias sobre 1964 e a ditadura militar. Revista Brasileira de História. 2004, vol. 24, no. 47 pp. 29-60. Disponível em: http://www.scielo.br/scielo.php?script=sci_arttext\&pid=S0102 $>$ Acesso em: 8 out. 2006.

PEREIRA, A. B. Muitas palavras: a discussão recente sobre juventude nas Ciências Sociais. Ponto Urbe: Revista do Núcleo de Antropologia Urbana da USP, v. 1, p. 1, 2007. ; Meio de divulgação: Digital; Homepage: http://n-au.org/pontourbe01/pereira-a-2007.html; ISSN/ISBN: 19813341. Acesso em novembro de 2007.

PROGRAMA VIA LEGAL. Portal da Justiça Federal. http://daleth.cjf.gov.br/ vialegal/? CodADireito=16, acessado em dezembro de 2007). Acesso em dezembro de 2007.

REIS FILHO, D.A. Os muitos véus da impunidade: sociedade, tortura e ditadura no Brasil. Especial para Gramsci e o Brasil. (Texto apresentado na Fundação Humberto Delgado, Lisboa, no colóquio sobre impunidade realizado entre 20 e 21 de maio de 1999). Disponivel em http://www. artnet.com.br/gramsci/ arquiv94.htm. Acesso em outubro de 2007.

SERRA, J. História da UNE. www.cinderela.com.br/republica/republ601.htm (entrevista de 1980) acessado em 29 jul.2000

SILVA, R. BITTENCOURT da. A construção simbólica do "populismo brizolista" operada pelo Jornal do Brasil. Revista Comum, Rio de Janeiro: Faculdades Integradas Hélio Alonso, vol.8, no21, pp.103 a 125, julho/dezembro 2003. Disponivel em: http://www. facha. edu.br/publicacoes/comum /comum21 106.pdf>Acesso em 8 out. 2006.

\section{Jornais}

AITH, M. O encontro secreto de Jango e Bob Kennedy: Secretário da Justiça dos EUA veio para o Brasil em 1962 para exigir que o presidente João Goulart definisse sua ideologia. FOLHA DE S.PAULO, 12 ago. 2001. Folha Mundo.

FAUSTO, B. As relações Brasil-EUA estavam estremecidas pelo crescente antiamericanismo de setores do país. FOLHA DE S.PAULO, 12 ago.2001. Folha Mundo. 


\section{Legislação}

Todas as leis disponiveis em:

http://www6.senado.gov.br/sicon/PreparaPesquisaLegislacao.action

ATO INSTITUCIONAL NÚMERO 2 DE 27/10/1965. Publicado em 27/10/1965 Diário Oficial da União. DOFC REP 05/11/1965 0113531 Diário Oficial da União.

BRASIL. CONSTITUIÇÃO DA REPÚBLICA DOS ESTADOS UNIDOS DO BRASIL DE 1946. DOFC PUB 19/09/1946. Diário Oficial da União.

DECRETO-LEI 314 DE 31/03/1967. DEFINE OS CRIMES CONTRA A SEGURANÇA NACIONAL, A ORDEM POLITICA E SOCIAL E DA OUTRAS PROVIDENCIAS. DOFC PUB 13/03/1967 0029931 Diário Oficial da União. DOFC RET 27/03/1967. Diário Oficial da União.

DECRETO-LEI 510 DE 20/03/1969 - DECRETO LEIALTERA DISPOSITIVOS DO DECRETO-LEI 314, DE 13 DE MARÇO DE 1967, E DA OUTRAS PROVIDENCIAS. PUBUBLICADO EM 21/03/1969. Diário Oficial da União.

DECRETO-LEI 898 DE 29/09/1969 - DEFINE OS CRIMES CONTRA A SEGURANÇA NACIONAL, A ORDEM POLITICA E SOCIAL, ESTABELECE SEU PROCESSO E JULGAMENTO E DA OUTRAS PROVIDENCIAS. Publicado em 29/09/1969. Diário Oficial da União.

DECRETO-LEI 925 DE 02/12/1938. Publicado em 31/12/1938. Coleção de Leis do Brasil. PUBLICADO EM 29/09/1969. Diário Oficial da União.

\section{Fontes documentais}

Aldo Arantes, José Serra, Altino Luís Guedes, Luís Raul Machado, Nilton Santos, Jean Marc Von Der Weird, Dora Rodrigues de Carvalho, José Genoíno Neto e Newton Mirando Sobrinho. Apud SANTOS, N. (org). História da UNE. Depoimentos de ex-dirigentes. São Paulo, Livramento, 1980.

Anexo 878 - (Carta política da UNE, 29 $9^{\circ}$ Congresso Nacional dos Estudantes em São Paulo). Periódicos Estudantis. Jornal do DCE, - Arquivo do Estado de São Paulo (AESP), Secretaria de Estado da Cultura; Governo do Estado de São Paulo. Fundo do Departamento Estadual de Ordem Política e Social (DEOPS/SP) - séries Dossiê.

ARQUIDIOCESE DE SÃO PAUlO. Projeto Brasil Nunca Mais (Tomo I, O Regime Militar). São Paulo: Arquidiocese de São Paulo, 1985a.

ARQUIDIOCESE DE SÃO PAULO. Projeto Brasil Nunca Mais (Tomo II, Os Instrumentos de Pesquisa e a Fonte). São Paulo: Arquidiocese de São Paulo, 1985b.

ARQUIDIOCESE DE SÃO PAUlO. Projeto Brasil Nunca Mais (Tomo III, Perfil 
dos Atingidos). São Paulo: Arquidiocese de São Paulo, 1985c.

ARQUIDIOCESE DE SÃO PAULO. Projeto Brasil Nunca Mais (BNM 5, BNM 163, BNM 354, BNM 401, BNM 408, BNM 429, BNM 489, BNM 535, BNM 623, BNM 690, e BNM 695). São Paulo: Arquidiocese de São Paulo, 1985d.

ARQUIDIOCESE DE SÃO PAUlO. Projeto Brasil Nunca Mais (Tomo IV, As leis repressivas). São Paulo: Arquidiocese de São Paulo, 1985e. 